Rosana Alcalde

\title{
CINOMOSE CANINA: DETECÇÃO DO RNA VIRAL PELA REAÇÃO EM CADEIA PELA POLIMERASE (RT-PCR) EM CÃES COM DIAGNÓSTICO CLÍNICO DA DOENÇA
}

Tese apresentada ao Instituto de Ciências Biomédicas da Universidade de São Paulo para obtenção do Título de Mestre em Ciências (Microbiologia).

São Paulo 
Candidato(a):

Título da Dissertação: Cinomose canina : detecção de RNA viral pela reação em cadeia pela polimerase (RT-PCR) em cães com diagnóstico clínico da doença.

A Comissão Julgadora dos trabalhos de Defesa da Dissertação de Mestrado, em sessão pública realizada a ....8.................9..., considerou o(a) candidato(a):

$(\times)$ Aprovado(a) 1 ) Reprovado(a)

1) Examinador(a)
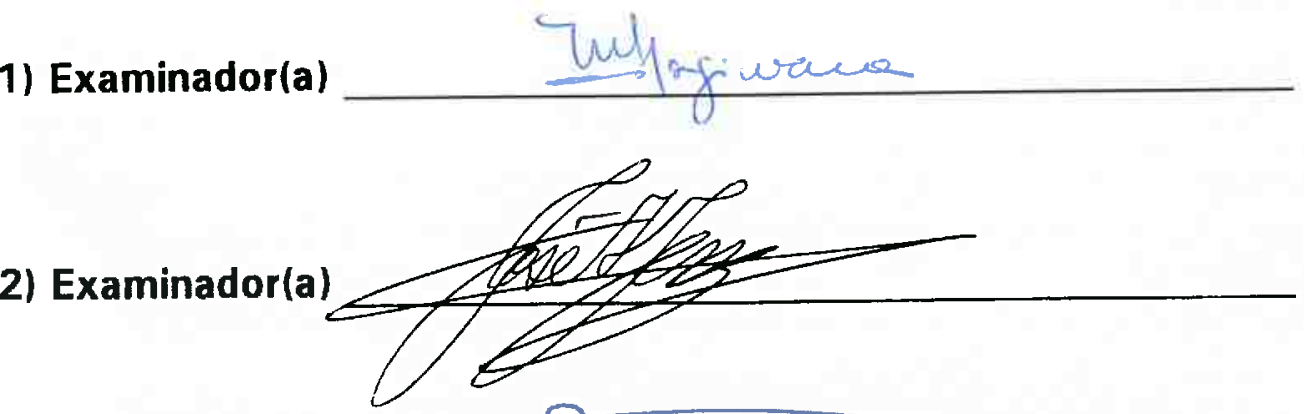

3) Presidente

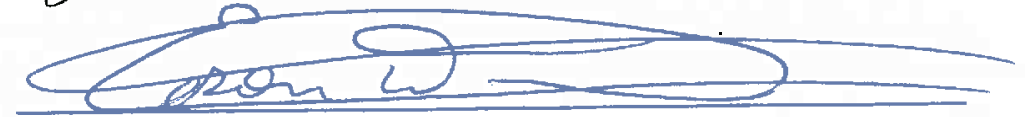


Rosana Alcalde

\section{CINOMOSE CANINA: DETECÇÃO DO RNA VIRAL PELA REAÇÃO EM CADEIA PELA POLIMERASE (RT-PCR) EM CÃES COM DIAGNÓSTICO CLÍNICO DA DOENÇA}

Tese apresentada ao Instituto de Ciências Biomédicas da Universidade de São Paulo para obtenção do Título de Mestre em Ciências (Microbiologia). Área de concentração: Microbiologia Orientador: Prof. Dr. Edison Luiz Durigon

São Paulo 1999

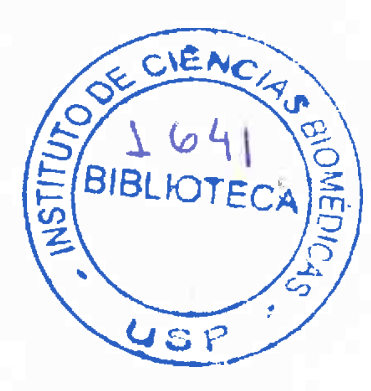


DADOS DE CATALOGAÇÃO NA PUBLICAÇÃO (CIP)

Serviço de Biblioteca e Informaçăo Biomédica do

Instituto de Ciências Biomédicas da Universidade de Sáo Paulo

\section{Alcalde, Rosana.}

T-ICB Cinomose canina : deteç̧ão de RNA viral pela reação em cadeia pela BMM polimerase (RT-PCR) em cães com diagnóstico clínico da doença / Rosana

A 346 C Alcalde. -- São Paulo, 1999.

1999

Dissertação(Mestrado)—Instituto de Ciências Biomédicas da Universidade de São Pauio. Departamento de Microbiologia.

Área de concentração: Microbiologia.

Linha de pesquisa: Virologia clínica e molecular.

Orientador: Durigon, Edison Luiz.

Versão do título para o inglês: Canine distemper virus : detection of viral RNA by RT-PCR in dogs with clinical diagnosis.

Descritores: 1.Cinomose canina 2. Vírus da cinomose canina 3. Reação em cadeia pela polimerase (RT-PCR) 4. Diagnóstico molecular 5. Excreção viral 6. Vias de eliminação viral 
"Chegará o dia em que o homem conhecerá o íntimo de um animal. $E$ neste dia todo crime contra um animal, será um crime contra a humanidade."

(Leonardo Da Vinci) 
Aos meus pais, Catharina Gaeta Alcalde e Juan Marcos Alcalde Rivas, exemplos de vida e coragem, pelo incentivo, apoio e constante presença nos melhores momentos da minha vida e pela minha formação pessoal.

Aos meus irmãos, João Marcos Alcalde e Rita de Cassia Aparecida Alcalde, pela amizade e ajuda no decorrer deste trabalho.

A Deus, pela constante presença em todos os momentos de nossas vidas, sem Ele nós não estaríamos aqui. 
Ao meu orientador, Prof. Dr. Edison Luiz Durigon, pelo apoio, incentivo e confiança em mim depositados, no início deste trabalho, oportunidade e credibilidade no ser humano, paciência, integridade $e$ por suportar minha insegurança e meu medo no desenvolvimento desta pesquisa, minha admiração e gratidão, pois sem essa chance eu não estaria aqui, escrevendo esta dedicatória.

"Somos maiores do que nossos medos e fracassos." 
A todos os cães e seus respectivos proprietários, que participaram deste trabalho, meu eterno agradecimento, pois sem esses não seria possível a realização do mesmo. 
- À Profa. Dra. Mitika Kuribayashi Hagiwara por sua dedicação, correção e sugestões tão importantes feitas na qualificação e no término desse trabalho.

- À Profa. Dra. Marcia Mery Kogika por "abrir as portas" do Hospital Veterinário e pela total confiança em nós depositadas, por suas sugestões tão valiosas e importantes.

- Às Dras. Vera A. Batistini Fortunato e Bruna Maria P. Coelho pela colheita das amostras clínicas e responsáveis pela avaliação clínica dos animais, sem a participação destas, este estudo seria inviável.

- Ao Prof. Dr. Leonardo José Richtzenhain e Prof. Dr. Hélio José Montassier, pelas sugestōes importantes feitas na qualificação desse trabalho.

- À minha colega Patricia Beltrão, por me apresentar ao meu orientador e pelos incentivos tão essenciais em minha carreira profissional.

- Ao meu amigo Luiz Carlos Vieira, pela ajuda, incentivo e dicas tão prestativas, pela amizade e apoio constantes em todos os momentos desse trabalho, minha eterna gratidão.

- Aos meus amigos Gilvan V. Santos, Alexandre Douglas Crispin, pela ajuda em informática, amizade e apoio constantes, Adélia Hiroko $N$. Kawamoto e Marina Favrin (pelas traduções de trabalhos escritos em francês), pelo incentivo e carona nas horas árduas, pela amizade e apoio constantes. 
- Ao meu grande amigo Oscar Gois Lima Junior pela amizade e companheirismo na época de Faculdade e pela indicação no trabalho quando eu mais precisei.

- À memória de meus tios João Gaeta e Rosa Maria Gaeta, pelos incentivos em minha carreira profissional e ajuda em horas árduas.

- À minha amiga Damiana Vieira Silva pela grande ajuda no momento que mais precisei, por sua amizade e dedicação.

- A todos os funcionários e bibliotecárias do ICB-USP, pela eficiência e gentileza constantes.

- Aos Profs. do Laboratório de Virologia do Departamento de Microbiologia do ICB-USP: Prof. Dr. Armando de Morais Ventura, Profa. Dra. Maria Lucia Rácz e Profa. Dra. Dolores Úrsula Mehnert, por cederem prontamente materiais e equipamentos de seus laboratórios.

- Aos funcionários do Departamento de Microbiologia, Sra. Antonia A. Rodrigues, Sra. Elaine F. Santos, Carlos Augusto Silva e José Maria Lopes, pelo suporte técnico (preparo dos materiais e vidrarias) necessários durante esse trabalho.

- Aos colegas do Curso de Pós-Graduação e do Laboratório de Virologia: Maria Isabel de Oliveira, Pedro Carnielli Junior, Aufra C. A. de Araújo, Luiz Fernando Zerbini, Lourdes R. Vaz de Lima, Viviane F. Botosso e César Dínola.

- Às funcionárias da secretaria de Pós-Graduação, em especial à Ana Maria França Amaral, pela grande ajuda em horas dificeis.

- À minha amiga Nancy Yuri K. de Amo, pela paciência e apoio em minhas inseguranças. 
- Ao acessor da FAPESP, por suas correções, sugestões e críticas construtivas tão indispensáveis no decorrer de todo esse trabalho.

- A FAPESP pelo suporte financeiro, que tornou possível a realização deste trabalho. 


\section{Índice}

Lista de Abreviaturas

Resumo

1- Introdução Geral

01

1.1- Agente etiológico...

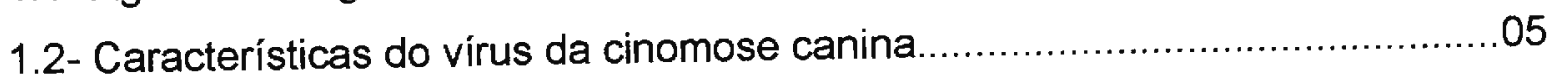

1.2.1- Replicação

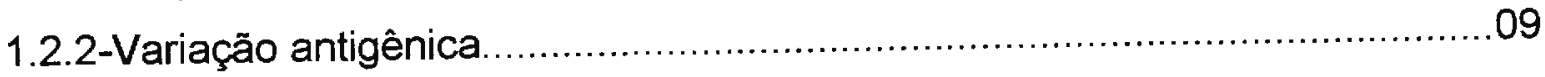

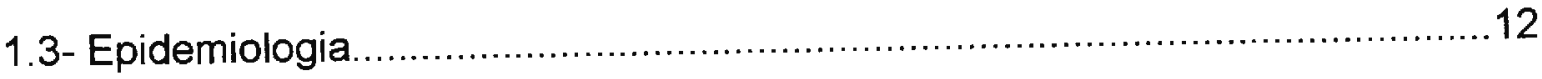

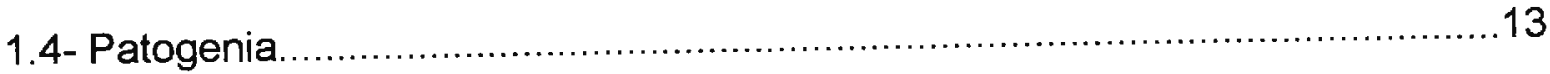

1.4.1- Infecção sistêmica.

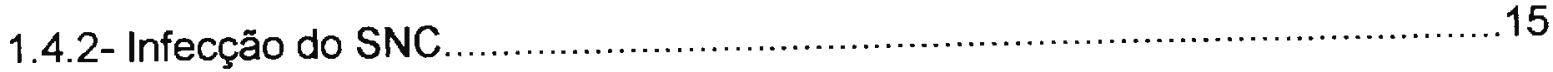

1.4.3- Manifestações clínicas

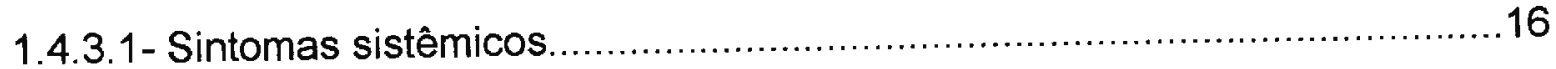

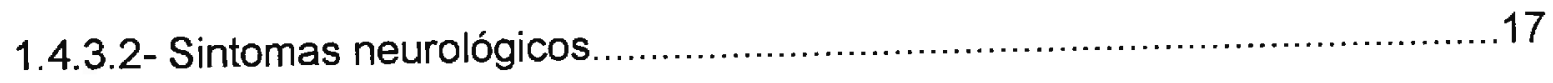

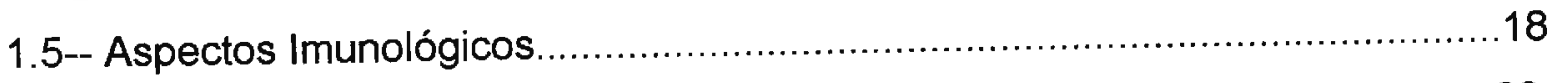

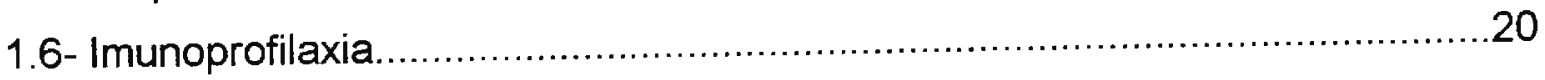

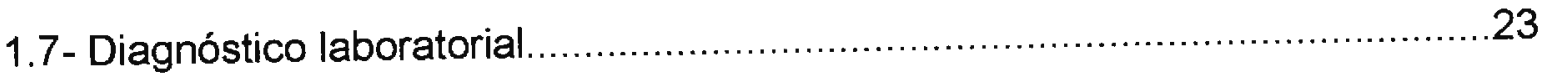

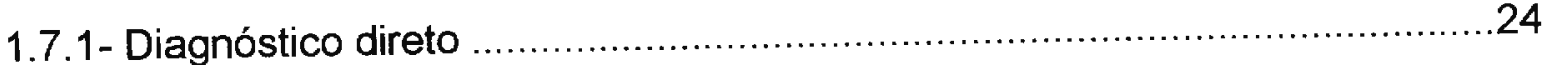

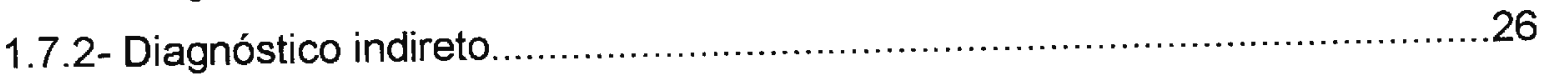

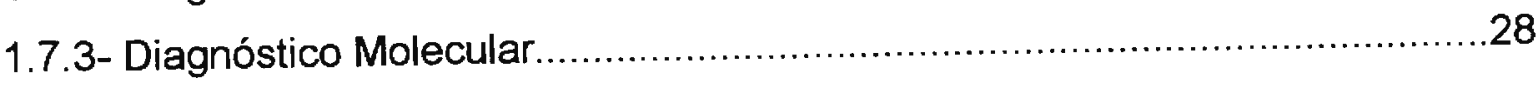

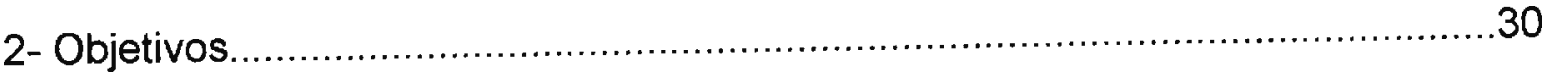

3- Materiais e Métodos

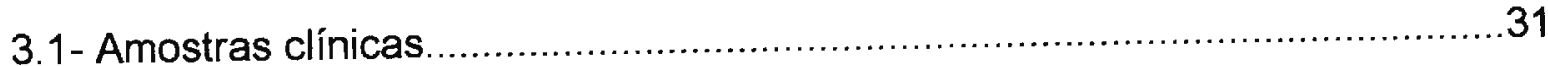


3.2- Processamento das amostras para PCR

3.2.1- Sangue venoso total, para obtenção de soro..........................................32

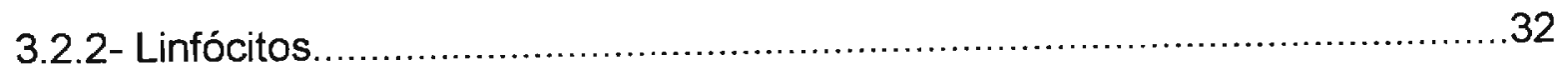

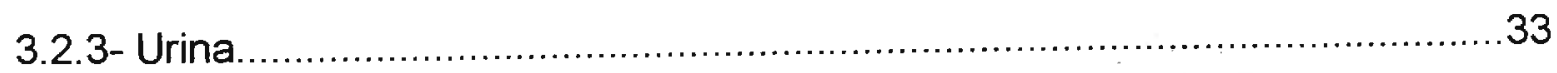

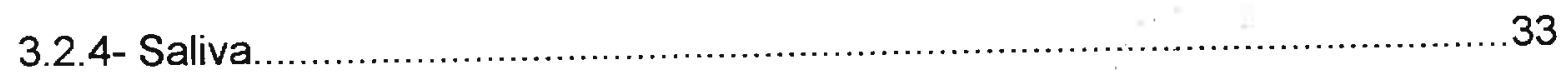

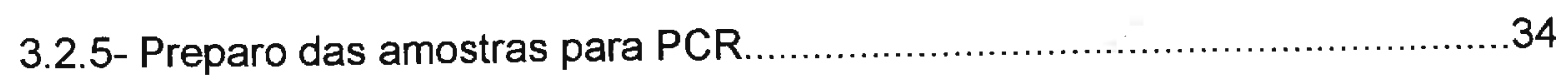

3.3- Reação de PCR

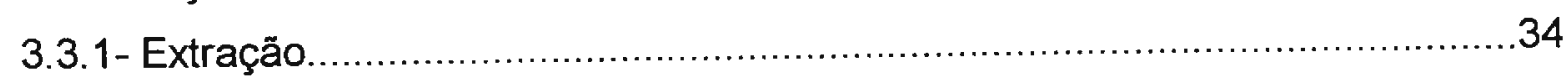

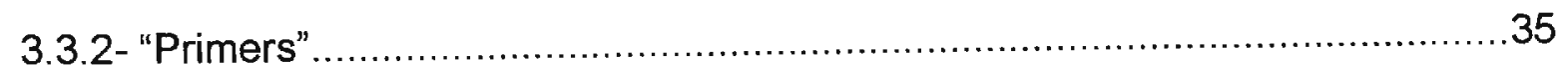

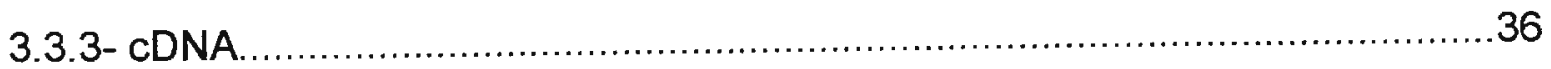

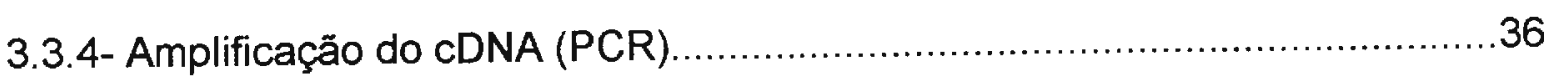

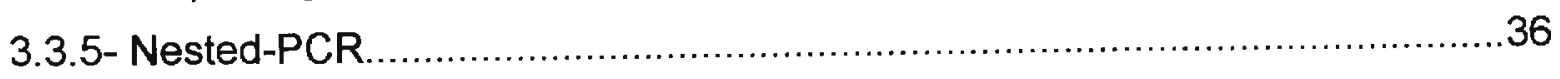

3.3.6- Visualização dos produtos amplificados ...............................................37

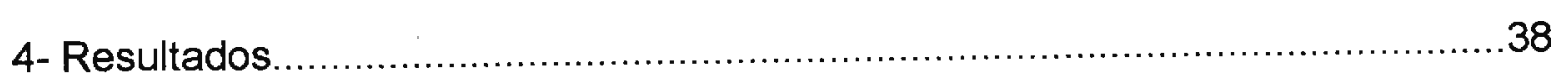

4.1- Deteç̧ão do RNA viral em amostras clínicas............................................41

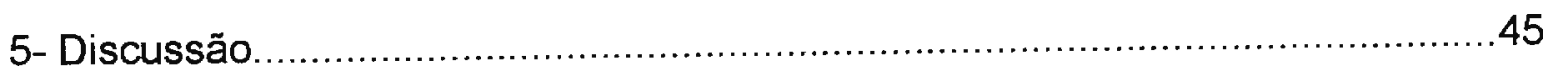

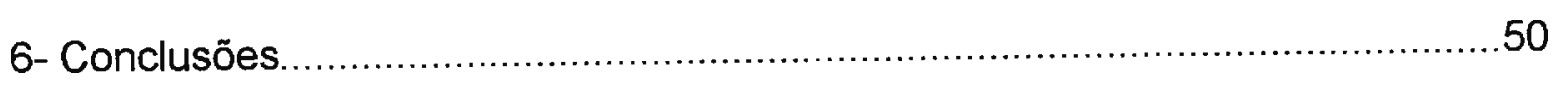

7- Referências Bibliográficas.......................................................................

Abstract

Anexos 


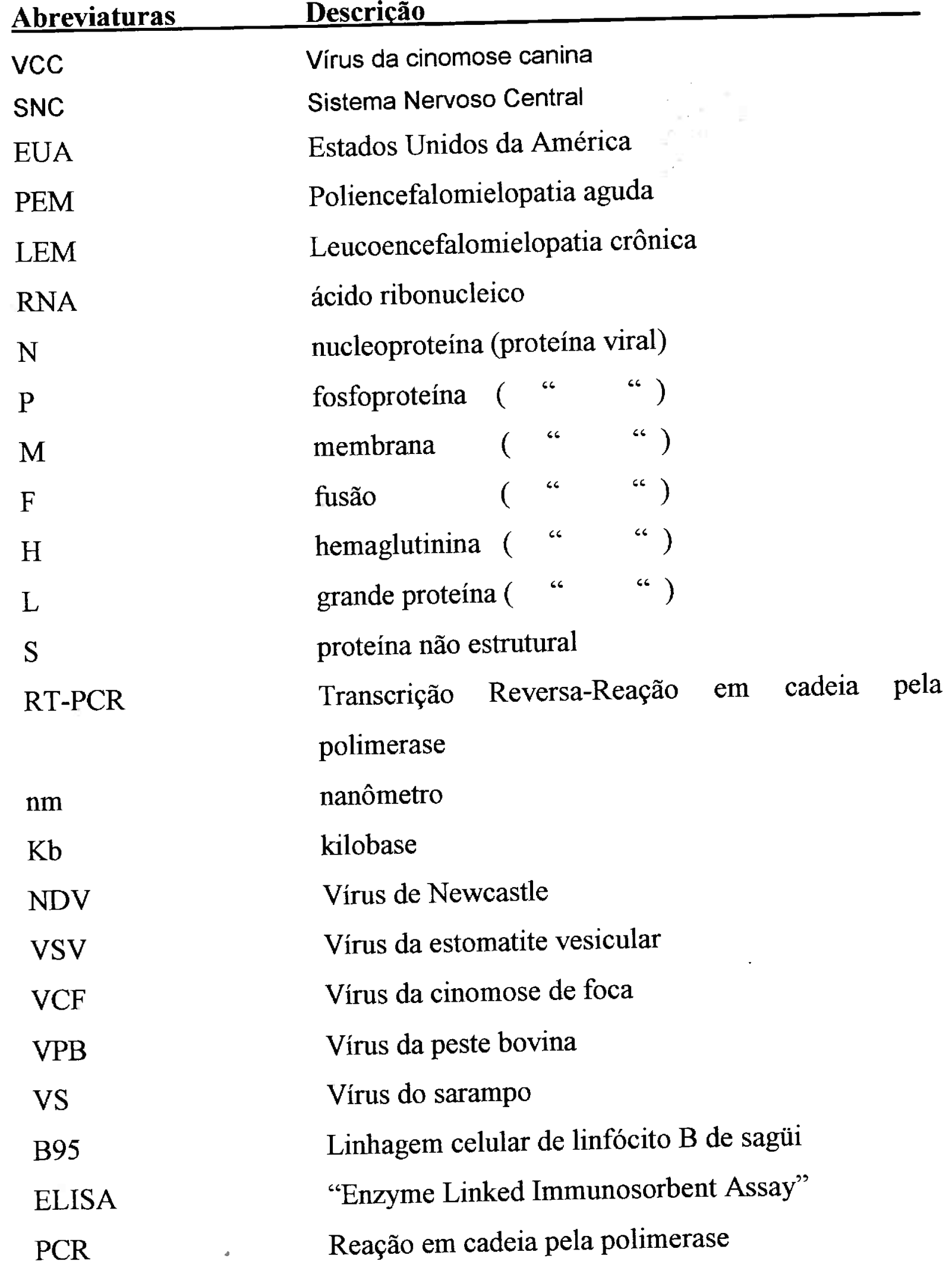


Abreviaturas

DNA

VCC-SH

VCC-RO

Hovet

$\mathrm{mL}$

$\mathrm{uL}$

PBS

SFB

EDTA

$\mathrm{mg}$

\section{Descricão}

ácido desoxirribonucleico

cepa do vírus da cinomose canina "Snyder Hill"

cepa do vírus da cinomose canina "Rockborn"

Hospital Veterinário da Universidade de São Paulo

mililitro

microlitro

solução salina tamponada com fosfatos

Soro fetal bovino

ácido etilenodiaminotetracético

miligrama 


\section{Resumo}

O vírus da cinomose canina (VCC) é um patógeno viral, altamente, contagioso que pode causar doença sistêmica letal, em cães e outros carnivoros em toda parte do mundo. Os cães afetados podem apresentar sintomas gastrentéricos, respitatórios e nervosos. As manifestações clínicas da doença inclue depressão, diarréia, vômito, desidratação, hiperqueratose dos coxins e focinho e espasmos musculares ou paresia de membros pélvicos, a qual pode persistir por longos períodos.

Cães infectados, com sintomas clínicos de VCC, foram estudados para detecção do RNA viral pela técnica de PCR e Nested-PCR.

Neste estudo, amplificou-se o gene da nucleoproteína (NP) em células mononucleares do sangue periférico (linfócitos), urina e saliva, de cães infectados com VCC, para detectar o genoma do mesmo, por RT-PCR, em diferentes amostras clínicas. A identificação do RNA viral foi concluída com sucesso, pelo método de RT-PCR, utilizando 2 pares de "primers" específicos do gene da nucleoproteína (NP). A técnica de RT-PCR, descrita neste etudo, pode ser um sistema de ensaio útil para determinar se cães suspeitos de infecção, por VCC, tenha níveis detectáveis de genes. Os resultados demonstram que a técnica de RT-PCR é exequível para o diagnóstico laboratorial de cinomose canina. 
1. INTRODUCÃO 


\section{INTRODUÇÃO GERAL}

A cinomose canina tem sido reconhecida no mundo, por séculos, como uma das mais importantes doenças infecciosas que acometem a espécie canina [Schlingman, 1933; Buxton et al.,1977; Fenner et al.,1993]. É uma doença sistêmica, que pode ser letal, aguda e/ou subaguda, altamente contagiosa [Hirayama et al., 1986], que causa mais morbidade e mortalidade, em cães jovens, especialmente aqueles com menos de 3 meses de idade, onde um grande número de cães são expostos à infecção, estes podem adoecerem e não resistirem à infecção ou recuperarem-se, tornando-se imunes [Swango, 1989; Greene \& Appel,1990]; e outros carnivoros do que qualquer outra infecção, tendo sido detectada em diferentes continentes [Svansson et al., 1993].

Os cães afetados apresentam sinais clínicos sistêmicos gastrointestinais e/ou respiratórios, freqüentemente, desenvolvendo sinais clínicos de comprometimento do SNC [Buxton et al.,1977; Appel, 1987; Durchfeld et al., 1990; Fenner et al., 1993; Mori et al., 1994].

O vírus da cinomose canina (VCC) causa infecção generalizada aguda ou localizada crônica e infecção persistente no Sistema Nervoso Central (SNC) de cães [Mitchell et al., 1987]. A persistência, in vivo, depois de uma recuperação clínica aparente tem sido proposta como um caminho para o desenvolvimento de encefalomielite desmielinizante crônica e encefalite em cães mais idosos, em animais convalescentes [Oglesbee et al., 1986].

Devido ao estreito contato entre cães e o homem, existe a possibilidade do VCC estar relacionado a doenças humanas como a esclerose múltipla e a doença de Paget [Cook et al. ,1978; Cartwright et al., 1993]. A doença de Paget é crônica e é caracterizada por uma progressiva destruição, remodelação e deformação do osso, com maior incidência no crânio, coluna vertebral e ossos pélvicos. Com o uso da técnica de hibridização "in situ", foi possivel a detecção do genoma responsável pela síntese do nucleocapsídeo viral em osteoclastos, osteoblastos e células mononucleares provenientes de biópsias de ossos de pacientes com a doença. Tais dados demostram, claramente, que o VCC pode residir em ossos de 
pessoas com esclerose múltipla. Se o vírus é um agente etiológico da doença ou uma infecção oportunista, resta ser estabelecido, embora evidências moleculares tenham implicado este vírus como um possivel agente etiológico da doença. [Cartwright et al., 1993; Gordon et al., 1993].

Estudos moleculares e epidemiológicos têm sugerido que o VCC seja o responsável pela doença de Paget. Se verdade, então, juntamente, com o vírus da raiva, este seria um outro exemplo de vírus canino causando doença humana. Estudos em hospedeiros naturais têm demonstrado essas caracteristicas [Mee \& Sharpe, 1993].

Evidências moleculares demonstram que o VCC está presente em, aproximadamente, $65 \%$ de amostras de ossos de pacientes com a doença de Paget, usando a técnica de RT-PCR (hibridização "in situ"), entretanto, esses resultados têm sido criticados. Para uma demonstração mais sensível e segura do possivel papel desse vírus, foi desenvolvida uma nova técnica de RT-PCR "in situ" (IS-RT-PCR) para examinar a presença do genoma responsável pela síntese do nucleocapsídeo viral em ossos de pacientes com a doença. A especificidade da técnica foi confirmada usando células Vero infectadas com VCC, as quais amplificaram seguindo a nova técnica (IS-RT-PCR). Seguindo a hibridização "in situ" convencional, o vírus foi detectado em 10 das 15 amostras de pacientes com a doença. Entretanto, seguindo a nova técnica, foi detectado em todas as 15 amostras examinadas. Esses resultados comprovaram que o VCC está presente em ossos de pessoas com doença de Paget, ajudando a confirmar a hipótese de que o Paramixovírus esteja envolvido na etiopatologia da doença de Paget [Mee et al., 1998].

Tem sido observada uma reatividade cruzada imunológica forte entre o VCC e o vírus do sarampo (VS), entre todos os polipeptídeos destes vírus, com a possivel exceção da hemaglutinina. Esses vírus podem estabelecer uma infecção persistente em cultura celular e ambos podem invadir o SNC do hospedeiro. Uma doença neurológica lentamente progressiva, conhecida como panencefalite esclerótica subaguda, tem sido diretamente correlacionada com a presença do vírus do sarampo no SNC em pacientes humanos. Igualmente, o vírus da 
cinomose tem sido mostrado como o agente causador de uma doença neurológica lenta em cães mais idosos [Rozenblatt et al., 1985; Rozenblatt et al., 1985].

O VS, outro membro do gênero Morbillivirus, estreitamente relacionado ao vírus da cinomose, foi detectado em amostras de urina, utilizando-se a técnica da Transcriptase Reversa - PCR (RT-PCR) [ Rota, et al., 1995].

Além dos canídeos, outras espécies animais também são susceptiveis ao VCC. Várias investigações têm demonstrado que muitos animais selvagens apresentam susceptibilidade a infecção pelo VCC e a taxa de mortalidade varia muito entre espécies [Appel \& Summers, 1995]; sendo comum entre os membros da família Canidae (cão doméstico, cão selvagem, lobo, raposa, coiote e chacal), Mustelidae (doninha, furão, texugo e marta), Procyonidae (jupará, guaxinim, qüati e panda) e Viverrridae (gato de algália). Há espécies susceptíveis para o VCC, mas com pouca evidência, distribuidas entre as famílias Protelidae (protelomamífero semelhante à hiena), Hyaenidae (hiena), Felidae (leão) e Viverridae (espécie de lêmure) [Anderson, 1995].

A toxoplasmose e o VCC são doenças comuns em Mustelideos, Procyonideos e Canideos selvagens. Moller (1951), considerou que a infecção por esse vírus pode diminuir a resistência e promover desenvolvimento de uma toxoplasmose latente, dentro de um processo de doença fulminante, com desenvolvimento de lesões herpéticas [Diters \& Nielsen, 1978].

Em 1989, foi relatada uma epidemia causada, pelo VCC, em macacos japoneses (Macaca fuscata), associada a um caso fatal de encefalite viral, sendo este o primeiro relato de uma infecção natural por este vírus em primatas não humanos [Yoshikawa, et al.,1989]. Foi relatado, também, que filhotes de cães de caça africanos morreram 3 semanas após terem sido vacinados com o VCC vivo modificado [Durchfeld et al., 1990].

Em 1988, foi constatado que, aproximadamente, 18000 focas morreram no mar no norte ocidental da Europa, como um resultado de infecção causada por um Morbilivirus desconhecido. Estudos posteriores mostraram que o virus era um Morbilivirus distinto do VCC [Curran et al., 1992]. 
O VCC, também, foi isolado de focas cinzas de cativeiro e outros animais marinhos, como o golfinho, na Universidade de Guelph, Ontario [Lyons et al., 1993]. O vírus, também, foi associado a infecções e morte de pandas gigantes na reserva de Wolong, China [Mainka et al., 1994]. O mesmo ocorreu em raposas vermelhas (Vulpes vulpes), em Galícia, no norte ocidental da Espanha [ Peña et al., 1994]; e sudeste dos Estados Unidos [Little et al., 1998].

\subsection{Agente etiológico}

A etiologia viral da doença foi demonstrada em 1905, por Carré, através da constatação de que a coriza nasal de filhotes de cães era, freqüentemente, virulenta. Algumas das alterações observadas foram: aumento de temperatura corpórea, coriza mais ou menos intensa, conjuntivite, sintomas respiratórios e rarefação pilosa peri-ocular. A seguir, o animal sofria um considerável emagrecimento e vinha a óbito por bronco-pneumonia. Esta experiência foi repetida inúmeras vezes com sucesso. Frente a idade, raça, como também quantidade de filtrado injetado, a reação, pós inoculação, foi mais ou menos intensa [Carré, 1905].

Estes resultados foram confirmados por Lignières, em 1906, sendo a etiologia viral confirmada em 1923, por Puntoni. Estudos mais detalhados foram feitos, por Dunkin e Laidlaw, em 1926, confirmando dados obtidos por Carré, e tiveram notável contribuição, incluindo a produção de um soro hiperimune, utilizado na profilaxia para os cães e o desenvolvimento de uma vacina efetiva contra cinomose na produção de imunização para os mesmos [Schlingman, 1933; Apple, 1969; Appel \& Gillespie, 1972; Buxton et al., 1977; Apple, 1987; Fenner et al., 1993].

Embora a etiologia da cinomose canina seja conhecida desde 1926, a patogenia da doença permaneceu obscura até o relato de Appel, em 1969. Este relato e um estudo posterior, em 1970, concedeu uma avaliação do curso da multiplicação do vírus, em cães, e a relação dos sinais de infecção [Love, 1972]. 
Puntoni (1923) e Dunkin e Laidlaw (1928), desenvolveram uma vacina com vírus inativado, que foi usada por décadas, com sucesso limitado. A doença foi controlada por uma vacina com vírus vivo atenuado desenvolvida por Cabasso et al. (1951), Haig (1956) e Rockborn (1960) [Buxton et al., 1977; Appel, 1987]. Goret (1936), na França, repetiu e confirmou os resultados sobre a patogenicidade do experimento de Dunkin e Laidlaw [Goret, 1950].

Larin (1955) afirmou que cepas do VCC foram distingüidas pelo curso da doença que elas produziam em furões infectados experimentalmente. Nas palavras de Richter (1908): " a diversidade dos sintomas em cinomose não é argumentação de que a infecção possa ser dividida em três ou mais doenças separadas" . Dunkin e Laidlaw (1926) também enfatizaram a grande variabilidade da severidade da doença [Cornwell et al., 1965].

\subsection{Características do vírus da cinomose canina}

O VCc é um membro da família Paramyxoviridae e pertence ao gênero Morbillivirus [Buxton et al., 1977; Bellini et al., 1986; Oglesbee et al., 1986; Appel, 1987; Mitchell et al., 1987; Curran et al., 1991; Fenner et al., 1993; BlixenkroneMoller, 1993; Zurbriggen et al., 1993; Greene \& Appel, 1998].

Segundo o Comitê Internacional de Taxonomia dos Vírus [Rima et al., 1995], a família Paramyxoviridae encontra-se dividida em 2 sub-famílias: Paramyxovirinae (vírus que infectam humanos, bovinos, murinos, símios, caninos e aves) e Pneumovirinae (vírus que infectam humanos, bovinos e perus). A subfamília Paramyxovirinae está dividida em 3 gêneros: Paramyxovirus, que inclue: parainfluenza bovino tipo 3 , parainfluenza humano tipo 1 e 3 , parainfluenza murino tipo 1 e parainfluenza símio tipo 10; Morbillivirus, que inclue: o vírus da cinomose canina, o vírus do sarampo, o vírus da peste bovina, cinomose de golfinho e foca; e Rubulavirus, que inclue: paramyxovirus aviário tipos $2,3,4,5,6,7,8$ e 9; parainfluenza humano tipo 2,4a e 4b; e caxumba. Esta classificação está fundamentada em. características especiais deste vírus, sendo que todos os 
Morbillivirus produzem corpúsculos de inclusões intranuclear e intracitoplásmico, que contém ribonucleocapsídeos virais [Rima et al., 1995].

O VCC é relativamente grande, variando de 150 a $250 \mathrm{~nm}$ [Greene \& Appel, 1998]. A partícula viral consiste de um RNA de fita negativa [Buxton et al., 1977; Bellini et al., 1986; Oglesbee et al., 1986; Mitchell et al., 1987; Curran et al., 1992; Blixenkrone-Moller, 1993; Zurbriggen et al., 1993; Murphy, 1996; Greene \& Appel, 1998]; em conjunto com a proteína do nucleocapsídeo, a maior proteína viral produzida em células infectadas [Oglesbee et al., 1986; Oglesbee et al., 1989]; não segmentado [Oglesbee et al., 1989; Vainionpää et al., 1989; Curran et al., 1991; Galinski et al., 1991; Curran et al., 1992]; com capsídeo de simetria helicoidal [Buxton et al., 1977; Bellini et al., 1986; Oglesbee et al., 1986; Curran et al., 1992; Blixenkrone-Moller, 1993; Zurbriggen et al., 1993; Greene \& Appel, 1998]; (16-20 Kb, em extensão) [Murphy, 1996]; é um vírus neurotrópico e linfotrópico [Löffler et al., 1997]. É circundado por um envelope lipoproteico [Buxton et al., 1977; Bellini et al., 1986; Appel, 1987; Curran et al., 1991; Blixenkrone-Moller, 1993; Greene \& Appel, 1998]; derivado da membrana da célula hospedeira [Wright et al., 1974; Vainionpää et al., 1989; Greene \& Appel, 1998], o qual apresenta 2 tipos de projeções. Estas projeções são compostas por 2 glicoproteínas, que são hemaglutinina e proteína de fusão $(H \in F)$ na parte externa. Na parte interna do envelope está a proteína de membrana (M) que é a responsável pela interação entre as proteínas $\mathrm{H}$ e $\mathrm{F}$ e o nucleocapsídeo do vírus [Appel, 1987; Fenner et al., 1993]. O nucleocapsídeo varia entre 13-18 nm em diâmetro [Murphy, 1996]; este é formado dentro do citoplasma da célula hospedeira [Wright et al., 1974; Greene \& Appel, 1998]. Os membros desta família são pleomórficos [Oglesbee et al., 1986; Vainionpää et al., 1989; Galinski et al., 1991; Fenner et al.,1993; Murphy, 1996].

O VCC apresenta 6 proteínas estruturais: a nucleoproteína $(\mathrm{N})$, que é a maior proteína viral, tem a função de envolver e proteger o genoma RNA, e é altamente conservada dentro da família Paramyxoviridae; enquanto que a fosfoproteína $(P)$, muito susceptível a proteólise, é fosforilada e a segunda mais abundante, e associada com as proteínas $\mathrm{N}$ e $\mathrm{L}$ no nucleocapsídeo, 
desempenham uma função direta de transcrição e replicação do RNA. A proteína da membrana (M) desempenha uma importante função durante a maturação do vírus, conferindo estabilidade ao envelope, enquanto que a proteína de fusão $(F)$ é essencial para penetração viral na célula hospedeira, por fusão do envelope viral com a membrana plasmática, disseminação, contribuindo para a indução de imunidade. A hemaglutinina $(H)$ é a segunda glicoproteína de superfície, induzindo a imunidade, adsorvendo o vírus à célula hospedeira. As proteínas $\mathrm{H}$ e $\mathrm{F}$ induzem a formação de anticorpos neutralizantes e conferem proteção contra a doença. Os anticorpos anti-F protegem mais do que os anti-H [Diallo, 1990]; e a chamada grande proteína $(L)$, transcreve o genoma. Essas proteínas manifestam níveis de reatividade cruzada sorológica [Rima et al., 1986; Oglesbee et al., 1989; Vainionpää et al., 1989; Diallo, 1990; Curran et al., 1991; Fenner et al., 1993].

A seqüência genômica a partir da extremidade $3^{\prime}$ é constituída pelo gene da proteína do nucleocapsídeo $(\mathrm{N})$, o gene da fosfoproteína $(\mathrm{P})$, o gene da proteína da matrix $(M)$, o gene da proteína de fusão $(F)$, o gene da proteína hemaglutinina $(H)$ e o gene da grande proteína $(L)$, a qual está próxima a extremidade 5 ' do genoma [Curran et al., 1992].

Todos os vírus do gênero Morbillivirus são altamente patogênicos. Felizmente, há vacinas efetivas atenuadas contra as doenças que causam. Mas, em países em desenvolvimento, devido às condições climáticas e conservação inadequada, às vezes, as vacinas são inativadas [Diallo, 1990].

Como outros virus que possuem envelope, a partícula do VCC é inativada, rapidamente, por solventes lipídicos, como clorofórmio e éter, por $0,05 \%$ de formalina em 4 horas a $37^{\circ} \mathrm{C}$ e $0,75 \%$ de fenol em 10 minutos a $4^{\circ} \mathrm{C}$. Solução de hipoclorito e agentes oxidantes também inativam o $\mathrm{VCC}$. $\mathrm{O}$ calor e a radiação destroem-no rapidamente. A partícula infecciosa permanece viável a $\mathrm{pH} 4,5-9,0$ [Buxton et al., 1977; Appel, 1987; Greene \& Appel, 1998]. O vírus sobrevive por meses a uma temperatura de $-10^{\circ} \mathrm{C}$ e indefinidamente a $-70^{\circ} \mathrm{C}$ ou quando liofilizado [Buxton et al., 1977; Appel, 1987]. 


\subsubsection{Replicação}

A adsorção do vírus na superfície celular é feita por um receptor celular, a proteína $H$. Nessa adsorção, o envelope viral funde-se com a membrana plasmática da célula hospedeira, liberando o nucleocápside para o citoplasma. A fusão ocorre com a participação das proteínas $\mathrm{F}$ e $\mathrm{H}$, embora esse mecanismo ainda não seja bem compeendido. A síntese de RNA começa, no citoplasma, após a penetração do genoma viral. O RNA é transcrito pela polimerase viral em RNAm, que servirá tanto como molde (para a fita negativa do genoma) para a replicação, como para a tradução dos genes em proteínas virais. As fitas da progênie viral são empacotadas na cápside proteica. Durante o último estágio da replicação viral, segmentos da membrana da célula hospedeira adquirem proteínas virais e características morfológicas das proteínas do envelope. Os nucleocapsídeos agrupam-se próximo a membrana celular e são, então, liberados da célula pelo processo de brotamento, adquirindo um envoltório lipoproteico, derivado da membrana da célula hospedeira. A proteína $M$ desempenha uma importante função na liberação do vírus maduro [Lamb \& Kolakofsky, 1996].

Aminoácidos específicos são essenciais para a replicação do VCC. Foi demonstrado que a privação da metionina suprime o crescimento do VCC, em células Vero, pela inibição da síntese do RNAm viral. A metionina é necessária para a replicação desse vírus, não somente em células Vero, mas também em células de neuroblastoma de rato e células de embrião de galinha. A inibição do crescimento do VCC, com a privação da metionina, em células Vero, foi mais proeminente do que com outros vírus, como por exemplo, vírus de Newcastle (NDV) e vírus da estomatite vesicular (VSV). Esta descoberta sugere que a metionina é essencial para o crescimento do VCC e que a replicação deste é mais dependente deste aminoácido do que outros vírus [Hirayama et al., 1985].

Foram determinadas condições ótimas para o isolamento e crescimento do VCC, em cultura de linfócito canino. O pico do título de anticorpos foi observado entre 3 a 6 dias pós-inoculação e dependeu da multiplicidade da infecção. A replicação do vírus em linfócitos resultou em maiores títulos do que quando 
replicados em macrófagos. Os linfócitos do sangue periférico, de cães imunes, foram tão susceptíveis, ao VCC, quanto foram os de cães susceptiveis não imunes [Appel et al., 1992].

\subsubsection{Variação antigênica}

Laidlaw e Dunkin desenvolveram testes de fixação de complemento para o VCC. Precipitações específicas deste podem ser demonstradas dentro de 6-8 horas em gel de agarose, por difusão com soro hiperimune de tecidos infectados contra anti-cinomose, anti-sarampo ou anti-peste bovina. Portanto pode-se estabelecer uma relação antigênica entre 0 vírus da cinomose, sarampo e peste bovina. Alguns exemplos dessa relação são: cães podem ser imunizados contra cinomose com o vírus da peste bovina; soro imune do gado contêm anticorpo neutralizante contra sarampo; cães com cinomose apresentam anticorpos para sarampo e pessoas com sarampo podem apresentar anticorpos neutralizantes para cinomose no soro e, ainda, cães e furões inoculados com vírus do sarampo podem manifestar proteção contra cinomose [Buxton et al., 1977].

Estudos de seqüenciamento do genoma do VCC têm demonstrado um grau de homologia de $53 \%$ no gene que codifica a proteina $\mathrm{H}$ e $77 \%$ de homologia no segmento do gene que codifica a proteína $\mathrm{N}$, quando comparado a outros Morbilivírus [Rozenblatt et al., 1985]. Foi feita uma comparação entre o vírus do sarampo e o VCC, para estabelecer o grau de homologia destes Morbilivírus. Foi demonstrado que o gene que codifica a proteína M teve $67 \%$ de homologia para a seqüência de nucleotídeos e $76 \%$ de homologia para a seqüência de aminoácidos [Bellini et al., 1986].

Foram usados anticorpos monoclonais para representar a relação antigênica entre os 3 tipos de Morbilivirus: o vírus do sarampo (VS), VCC e o vírus da peste bovina (VPB); contra as proteínas: hemaglutinina $(H)$, fusão $(F)$, nucleocapsideo (NP), fosfoproteína (P) e matrix (M). Nove cepas do VS, três cepas do VCC e quatro cepas do VPB foram examinadas pelo ensaio de radioimunoprecipitação e imunofluorescência, para reatividade com os anticorpos heterólogos. A proteina NP e, em particular, a proteína F dos Morbilivírus, 
mostraram um alto grau de homologia entre os epítopos; as proteínas $P$ e $M$, mostraram uma homologia parcial; $e$ a proteina $H$ mostrou um baixo grau de homologia. Estes dados indicaram que o melhor antígeno para proteger cães, em vacinação "heterotípica" é o antígeno $F$. Essas reatividades cruzadas e reações do tipo específica foram obtidas com as proteínas virais internas (M, $P$ e NP) [Sheshberadaran et al., 1986].

Foi feito um estudo designado para comparar as propriedades biológica e molecular das cepas do VCC. Diferenças marcantes foram observadas em algumas propriedades biológicas, entretanto, pouca diferença foi observada nas propriedades moleculares, tal como proteínas virais e RNAs. Foram estudadas 10 cepas, as quais poderiam ser divididas dentro de 3 grupos, pela eficiência na formação de dermatite pustular. Notavelmente, as 3 cepas virulentas mostraram pouca capacidade de formação de dermatite pustular, comparada com uma moderada capacidade das 7 cepas atenuadas. Esses resultados parecem ser plausiveis pelo fato de que todas as cepas atenuadas, mas nenhuma das cepas virulentas foram passadas em embriões de galinha. Entretanto, alguma outra cepa vacinal, que foi atenuada, por passagens em células de rim de cão, também, demonstrou ter moderada capacidade para formação de dermatite, em um outro experimento. Esses resultados sugerem que a capacidade dessa formação pode estar associada com atenuação [Hirayama et al., 1986].

Foram examinadas 3 propriedades biológicas, do VCC, para determinar se haveria alguma diferença entre a cepa selvagem e vacinal do vírus. As propriedades foram a habilidade de infectar macrófagos e células epiteliais, produzir efeito citopático em diferentes linhagens celulares, e se replicar na membrana corioalantóide de ovos embrionados de galinha. Para esse estudo, foram usadas 4 cepas vacinais e 5 isolados selvagens. Das 3 propriedades estudadas, somente a comparação da habilidade dos vírus de infectar macrófagos e células epiteliais foram um coerente marcador da origem do vírus. Os isolados selvagens infectaram somente cultura de macrófagos, enquanto que as cepas vacinais infectaram ambos os tipos de células. Um isolado selvagem não virulento, 
de um caso de encefalite de cão mais idoso, reagiu como uma cepa vacinal, por infectar ambos os tipos de células [Evans et al., 1991].

Em um estudo, foram isolados 2 Morbilivírus de foca (Phoca sibirica e Phoca vitulina), na Sibéria, em 1987, e no noroeste da Europa, em 1988, durante uma eclosão de doença que se assemelhava à cinomose em cães. Nessas viroses, vírus da cinomose de foca tipo 1 e tipo 2 (VCF1/2), respectivamente, foram identificados como o primeiro caso a ser observado. Foi feita uma comparação entre o VCF-1 e 2 e o VCC. Os dados mostraram que o VCF-1 era totalmente distinto do VCC, entretanto que o VCF-2 poderia não ser distingüido deste vírus. Observações de cães infectados foram feitas, mostrando uma alta e maior resposta imunológica para VCF-1, em relação aos outros 2 vírus; sendo que os cães infectados com VCF-2 desenvolveram resposta similar para as 3 viroses, havendo, ai, a primeira indicação da diferença biołógica entre VCF-1 e 2. Observações feitas, naturalmente, em focas infectadas mostrou que as VCF-1, geralmente, desenvolviam altos títulos de anticorpos para VCF-1, mais do que para VCF-2 e VCC, entretanto as VCF-2, geralmente, desenvolviam altos títulos de anticorpos para VCF-2 e VCC, mais do que para VCF-1. Esses relatos mostram que os 2 vírus de focas são totalmente distintos entre si [Visser et al., 1990; Svansson et al., 1993].

Um estudo, aonde foram analisadas as propriedades moleculares da proteína do nucleocapsídeo (NP), do VCC, isoladas entre 1992 e 1995, foi realizado no Japão. Foram obtidos 4 isolados (cepas Yanaka, Ueno, Hamamatsu e Adachi) observando-se que eram antigenicamente idênticos. Análises das seqüências de toda região do gene NP, de um isolado, a cepa "Yanaka", revelou que o gene NP continha 1683 nucleotídeos e um índice de $93,2 \%$ de homologia com uma cepa laboratorial, a cepa "Onderstepoort". A seqüência de aminoácidos continha 523 aminoácidos e foi $95,2 \%$ e $99 \%$ homólogas à cepa "Onderstepoort" e uma cepa virulenta, a "A75/17", respectivamente [Yoshida et al., 1998]. 


\subsection{Epidemiologia}

O VCC é enzoótico, na maioria das áreas do mundo, exceto em regiões quentes e áridas. A epizootia, em cães, ocorre em áreas isoladas onde a doença estava inexistente, por muitos anos e onde há uma população de cães altamente susceptíveis [Appel, 1987]. O VCC encontra-se, em abundância, em exsudatos respiratórios, entretanto, podendo ser isolado de outros tecidos do corpo e secreções, incluindo urina. Cães que não recebem imunização periódica podem perder a proteção e tornar-se susceptíveis à infecção, em seguida à situações de estresse, imunossupressão ou contato com outros cães doentes. As raças de cães mais comumente e severamente afetadas incluem: Greyhounds, Husky Siberiano, Weimaraner, Samoeda e Alaskan Malamutes. A virulência é outro parâmetro que pode afetar a severidade e extensão ou tipo de doença clínica. Certos isolados, como a cepa "Snyder Hill" ou "R252", são altamente virulentas e neurotrópicas. Outros isolados podem variar e causar lesões no SNC [Greene \& Appel, 1990]. Infecções, pelo VCC, são freqüentes em cães de regiões urbanas, em canis e em outras situações onde há contato entre cães doentes em lugares fechados [Fenner et al., 1993]. A taxa de mortalidade, seguindo infecção, pelo VCC, varia com espécies de hospedeiro, alcançando $0 \%$ em gatos domésticos, aproximadamente, $50 \%$ em cães domésticos e 100\% em furōes [Löffler et al., 1997].

Estudo feito com 236 carnivoros selvagens, 146 mustelídeos e 90 raposas, originários da mesma área geográfica, no norte da Alemanha, mostrou a presença do VCC nessa região. $O$ antígeno foi encontrado no cérebro de 54 mustelídeos, predominantemente na massa cinzenta do cérebro. Um aumento no número de infecções por esse vírus foi observado entre novembro de 1989 e novembro de 1990, no pico do verão [van Moll et al., 1995].

Estudos em ursos mostraram que estes animais podem ser susceptiveis ao VCC. O estudo foi realizado no Parque Nacional Abruzzo, na Itália, dentro de uma área de proteção; as amostras foram coletadas entre 1991 e 1995. O objetivo foi determinar a evidência sorológica dos patógenos virais que causam mortalidade em carnívoros, incluindo o VCC. Constataram que os ursos nunca haviam sido 
vacinados e verificaram que 3 de 9 ursos livres apresentavam anticorpos contra esse vírus e, 1 de 6 , ursos capturados apresentavam anticorpos. Este foi o primeiro relato, de VCC, em população de ursos [Marsilio et al., 1997].

Em 1994, ocorreu uma epidemia, em uma populaçăo de leões (Panthera leo), no ecossistema Serengeti (Leste da África), envolvendo doença neurológica, encefalite e pneumonia, causando a morte de $30 \%$ da população. Os sintomas incluiam: mioclonias e anorexia. Análise histopatológica da pele revelou corpúsculos de inclusões típicos do VCC. O vírus era mais patogênico em leões e hienas do que previamente observado em outras epidemias causadas por esse mesmo agente. Foi feita uma comparação da seqüência das proteínas Morbilivirais $(\mathrm{P}$ e $\mathrm{H})$. A proteína $\mathrm{H}$ adsorve o vírus a célula hospedeira, é um determinante, o qual varia de hospedeiro e causa patogenicidade. A proteína $\mathrm{P}$ é altamente conservada. Essa análise mostrou que os carnívoros do Serengeti são susceptíveis ao VCC sendo distinto das demais cepas virais de outras localidades geográficas. A distinção genética aumentou a patogenicidade em leões. $O$ cão doméstico é um reservatório natural para o vírus e tem soroprevalência [Carpenter et al., 1998].

\subsection{Patogenia}

Caracteristicamente, a cinomose canina acomete, principalmente, cães jovens ( 3 a 6 meses de idade) e, raras vezes, cães mais idosos, devido a imunidade natural. A doença tem um período de incubação de, aproximadamente, 3 a 7 dias, seguida de febre, conjuntivite, sintomas gastrentéricos e respiratórios (rinite, broncopneumonia). A doença parece ter uma prevalência periódica, com uma alta prevalência nos meses de inverno, sendo que epidemias severas tendem a ocorrer em 2 ou 3 ciclos, anualmente [Buxton et al., 1977; Fenner et al., 1993].

$O$ vírus da cinomose atua sobre o sistema linfóide, e a imunossupressão decorrente contribui para o agravamento da doença, permitindo o estabelecimento de infecções secundárias [Appel, 1987; Shin et al., 1995]. 
Foram avaliadas lesões de pele, em cães, com sintomas clínicos sugestivos de cinomose, tais como: dermatites pustular e vesicular, hiperqueratose dos coxins e rarefação pilosa peri-ocular. Observou-se no histopatológico da pele, presença de células gigantes sinciciais multinucleares [Summers \& Appel, 1985]; reunidas com corpúsculos de inclusão citoplásmico e nuclear, contendo partículas e antigeno virais [Maeda et al., 1994].

A infecção predominante inicial, pelo Paramixovírus, ocorre no sistema respiratório, vias aéreas anterior e posterior. Entretanto segundo Sidhu et al., (1993), em casos de sarampo e cinomose, a disseminação sistêmica do vírus pode ocorrer, primeiramente, no SNC.

\subsubsection{Infecção Sistêmica}

Durante a exposição natural, o VCC se dissemina, por aerosol e contato do epitélio do trato respiratório anterior. No período de 24 horas, o vírus se multiplica nos macrófagos e se dissemina para as células das tonsilas e linfonodos bronquiais. Por 2 a 4 dias pós-infecção, a carga viral aumenta nas tonsilas e nos linfonodos bronquiais, mas um número inferior de células mononucleares infectadas, são encontradas em outros órgãos linfóides. Por 4 a 6 dias pós infecção, a multiplicação do vírus ocorre dentro dos folículos linfóides do baço, timo, na lâmina própria do estômago e intestino delgado, nos linfonodos mesentérico e cervical e nas células de Kupffer do fígado, desenvolvendo a viremia. A proliferação do vírus, nos órgãos linfóides, coincide com o desenvolvimento de febre e leucopenia. A leucopenia é decorrente de linfopenia, devido ao dano viral às células linfóides, afetando ambas, as células T e B. Após 8 a 9 dias de infecção, uma nova disseminação do VCC ocorre no epitélio, o que se caracteriza pela manifestação dos sintomas clínicos, tais como: diarréia, vômitos e conjuntivite. Na dependência do estado imune do animal, outros órgãos poderão ser comprometidos como os rins, bexiga e SNC. Ainda, após 14 dias de infecção, os animais com títulos de anticorpos adequados podem ser assintomáticos da doença [Appel, 1969, Appel, 1970; Appel, 1987; Fenner et al., 1993]. Já os cães 
que apresentam baixo título de anticorpo no período de 9 a 14 dias pós-infecção, o vírus pode se disseminar para outros tecidos, incluindo pele, glândulas exócrina e endócrina. A manifestação da doença depende da estirpe viral, idade e imunocompetência do cão [Thomas et al., 1993; Thomas et al., 1998]. A infecção em cães jovens, geralmente, resulta em poliencefalomielopatia aguda (PEM) e alta mortalidade, enquanto que em cães mais idosos, esta se desenvolve, principalmente, em leucoencefalomielopatia crônica (LEM) com um baixo índice de mortalidade. O diagnóstico presuntivo de encefalomielite decorrente da infecção pelo vírus da cinomose, geralmente, é baseado na estória e evolução dos sintomas clínicos [Thomas et al., 1993].

Com o aumento do título de anticorpos, a infecção viral nos diversos tecidos orgânicos é debelada, mas pode persistir por longos períodos na úvea, neurônios e coxins. A proteção desses cães pode estar comprometida se o mesmo for exposto a um agente, altamente virulento, ou a uma grande carga viral, ou ainda imunocomprometido ou submetido à estresse [Greene \& Appel, 1998].

\subsubsection{Infecção do SNC}

A disseminação do vírus, no SNC, depende da resposta imune sistêmica do hospedeiro. O VCC causa uma encefalomielite em cães, que varia com a cepa viral [Pearce-Kelling et al., 1990]. O vírus, provavelmente, entra no sistema nervoso de muitos cães infectados apresentando ou não sintomas neurológicos. $O$ vírus (livre ou associado a linfócito) pode entrar nas células endoteliais vasculares nas meninges, células epiteliais do plexo coróide do $4^{\circ}$ ventrículo e células ependimais do sistema ventricular. O tipo de lesão e o curso da infecção, no SNC, depende de certos fatores, incluindo a idade e a imunocompetência do hospedeiro e as propriedades imunossupressiva e neurotrópica do vírus. Entre o $12^{\circ}$ e $016^{\circ}$ dias, de infecção pode ocorrer elevação de temperatura corpórea, acompanhada de progressiva perda de peso, depressão e perda de apetite [Appel, 1969, Appel, 1970; Appel, 1987; Fenner et al., 1993]. As encefalites aguda ou crônica podem ocorrer, independentemente, ou as lesões da fase aguda podem progredir para a 
forma crônica em animais que sobrevivem. A persistência do VCC é essencial para indução a uma doença desmielinizante, progressiva e crônica que leva a desmielinização do SNC, existindo uma associação entre a persistência e a virulência [Vandevelde et al., 1995]. O VCC virulento isolado de cães com cinomose mostra imediata replicação em cultura de célula primária de cérebro de cão. Há evidências que a proteína do nucleocapsídeo (NP) desempenha um importante papel no desenvolvimento desta replicação. A referida proteína consiste em estrutura viral mais abundante, que influencia na estrutura do vírus e tem algumas funçōes regulatórias na transcrição e replicação viral [Stettler \& Zurbriggen, 1995]. As doenças inflamatórias do SNC são causas importantes de derrame cerebral em cães. Muitas dessas doenças são causadas por agentes infecciosos como vírus, protozoários e fungos, embora haja outros casos em que a etiologia ainda não seja conhecida [Thomas, 1998].

O VCC causa lesões multifocais na massa branca e cinzenta do SNC [Zurbriggen et al., 1998]. As lesões da massa cinzenta resultam predominantemente em encefalite. As lesões da massa branca caracteriza-se por lesões na bainha de mielina (desmielinização), que está associada com a replicação do VCC em neurônios e células da glia, durante um período de intensa imunossupressão induzida pelo vírus [Vandevelde et al., 1995; Greene \& Appel, 1998]. Observou-se ausência do vírus em cães que desenvolviam anticorpo e sobreviviam, exceto em alguns, em que o vírus se localizava em neurônios e células epidermais dos coxins, caracterizando a presença de encefalite, paralisia de membros e hiperqueratose de coxins [Appel, 1969, Appel, 1970; Appel, 1987; Fenner et al., 1993].

\subsubsection{Manifestações Clínicas}

\subsubsection{Sintomas sistêmicos}

Os sintomas clínicos observados na infecção pelo VCC, variam dependendo da virulência da cepa viral, condições ambientais, idade e estado 
imune do hospedeiro [Greene \& Braund, 1989]. As manifestações clínicas da doença, seguindo infecção natural, incluem depressão, perda progressiva de peso, conjuntivite purulenta, desidratação, hiperqueratose dos coxins e focinho, sintomas respiratórios e nervosos, espasmos musculares ou paresia de membros pélvicos, a qual pode persistir por longos periodos [Schlingman, 1933]. A taxa de mortalidade é variável, mas em casos menos grave, geralmente, é baixa e algumas observações consideram que $50 \%$ a $70 \%$ das infecções são assintomáticas [Greene \& Appel, 1998]. Complicações como pneumonia e encefalite ocorrem em, aproximadamente, $50 \%$ dos casos, e esses podem ter uma taxa de mortalidade de 70 a 80\% [Buxton et al., 1977; Fenner et al., 1993].

\subsubsection{Sintomas neurológicos}

O quadro neurológico, geralmente, se inicia no período de 1 a 3 semanas após a manifestação dos sintomas sistêmicos; entretanto, não há possibilidade de prever se o cão desenvolverá alterações neurológicas. Cães que desenvolvem hiperqueratose digital e nasal, geralmente, podem apresentar várias complicações neurológicas. Cães adultos ou parcialmente imunes que foram previamente vacinados podem desenvolver repentinamente sintomas neurológicos, sem manifestação anterior de outros sintomas. Os sintomas neurológicos, agudo ou crônico, são típico, progressivo e variam de acordo com a área comprometida do SNC [Greene \& Appel, 1998].

Filhotes infectados, por via transplacentária, podem desenvolver sintomas neurológicos durante as primeiras 4 a 6 semanas de vida. Na dependência do periodo de gestação em que a infecção ocorreu, observa-se abortamentos ou nascimento de animais debilitados; entretanto quando esses sobrevivem podem apresentar imunodeficiência permanente. Filhotes infectados com o VCC, antes do aparecimento da dentição permanente, podem apresentar severo dano no esmalte, dentina ou raiz dos dentes. Sintomas clínicos, incluindo dispnéia, depressão, anorexia, colapso e prostração, podem surgir entre $014^{\circ}$ e $18^{\circ}$ dias pós infecção. As lesões oftalmológicas, na cinomose canina, tem sido atribuída a 
presença do vírus no nervo óptico e na retina, manifestando-se com perda da acuidade visual e midríase [Greene \& Appel, 1998].

Observou-se que cães com artrite reumatóide apresentam niveis elevados de anticorpos para VCC no soro e fluído sinovial, enquanto que cães com artrite inflamatória e degenerativa apresentavam niveis mais baixos. Ainda, o antígeno foi encontrado no complexo imune presente do fluído sinovial de cães com artrite reumatóide, inexistindo em cães com artropatias inflamatória ou degenerativa [Bell et al., 1991; Fenner et al., 1993; Greene \& Appel, 1998].

\subsection{Aspectos imunológicos}

O envelope do Paramixovírus contêm 2 glicoproteínas de superficie, as quais são alvo para o mecanismo de defesa do hospedeiro. Em geral, a hemaglutinina $(\mathrm{H})$ é o principal antígeno envolvido em neutralização "in vitro", mas em neutralização "in vivo", a proteína responsável é a de fusão $(F)$, prevenindo a expansão da infecção e o desenvolvimento da doença [Norrby et al., 1986].

A resposta imune, em cães, pelo $\mathrm{VCC}$, depende da cepa viral e do hospedeiro. Alguns cães desenvolvem uma resposta imune precoce $e$ restabelecem-se rapidamente; em outros, a infecção viral dos tratos respiratório, intestinal e urogenital levam à óbito. Durante esta fase, os cães apresentam linfopenia e ficam imunossuprimidos. Os anticorpos das classes IgM e IgG aparecem no início da infecção, sendo que a IgM pode ser detectada por 5 semanas a 3 meses, após a infecção. A lgG é a imunoglobulina mais importante para a imunidade. Grande variação na resposta imune é observada, em cães, que não chegam a óbito, por cinomose canina crônica ou subaguda e cães que sobrevivem a uma infecção persistente no SNC. Alguns cães desenvolvem uma desmielinização, aproximadamente 1 mês após a infecção. Os cães que sobrevivem à cinomose apresentam uma imunidade de longa duração. Anticorpos neutralizantes são transferidos para progênie através do colostro. O fluído cerebro-espinhal de cães que se recuperam está, geralmente, livre de anticorpo e interferon. Cães que têm sido vacinados com VCC inativado não são protegidos 
contra infecção com vírus selvagem, mas são protegidos contra a doença clínica. As glicoproteínas virais ( $\mathrm{H}$ e $\mathrm{F}$ ) induzem proteção em cães, mas os que têm sido vacinados com VCC vivo atenuado adquirem longa imunidade. O fluído cerebroespinhal permanece livre de anticorpos neutralizantes e interferon em cães vacinados [Appel, 1987; Fenner et al., 1993].

Em 1991, alguns cães foram submetidos a infecções experimentais com algumas cepas virulentas do VCC, como a "A75-17" ou "R252", que poderiam levar a produzir diferentes resultados da doença. Alguns cães desenvolveram lesões de desmielinização aguda e vieram a óbito devido a encefalite precoce; alguns apresentavam uma encefalite subaguda com desmielinização crônica e outros superaram a infecção e sobreviveram. A habilidade, desses cães, de superarem a infecção está associada à indução da resposta imune celular e humoral. Foi demonstrado que a resposta imune humoral, incluindo o desenvolvimento de anticorpos neutralizantes, é necessária para a liberação do vírus e proteção da doença. Krakowka et al. (1975), relataram que a redução do anticorpo para glicoproteina induziu o desenvolvimento de lesões cerebrais em cães infectados com a cepa "R252", baseados nos testes de anticorpos neutralizantes, enquanto que, em cães que se restabeleceram, foram encontrados anticorpos para o nucleocapsídeo e glicoproteína. Muitos cães com encefalite experimental e também cães com encefalite natural têm apresentado resposta imune humoral restrita para as proteinas internas, como por exemplo, a proteína do nucleocapsídeo $(\mathrm{N})$, a fosfoproteína $(\mathrm{P})$ e a proteína da membrana $(\mathrm{M})$ [Rima et al., 1991].

A cepa "BS-C-I:37", isolada localmente, foi estabelecida como imunogênica para cães e furões, mas ainda, mantendo alguma patogenicidade para os cães. Esta cepa tem produzido altos títulos de anticorpos neutralizantes. Passagens do vírus vacinal, em cães, não demonstrou nenhuma reversão para virulência [Geering, 1967].

Em 1969, Appel demonstrou que quando cães susceptíveis eram expostos ao vírus patogênico da cinomose canina, na forma de aerosol, $50 \%$ deles vieram a 
óbito em, aproximadamente, 3 semanas, sem apresentar anticorpos, entretanto os que sobreviviam desenvolviam anticorpos no $9^{\circ}$ dia com título maior do que 1:100.

Gerber e Marron (1976) relataram que cães vacinados com o VCC produziam tanto resposta mediada por célula quanto por anticorpo para ambos os virus, sarampo e cinomose, enquanto que cães vacinados com o VS produziam resposta mediada por célula e anticorpo para o sarampo, mas apenas mediada por célula, para cinomose [Chalmers \& Baxendale, 1994].

A distribuição do VCC foi examinada por imunohistoquimica com anticorpos monoclonais específicos. $O$ antígeno viral foi localizado em células T-dependente e em folículos de órgãos linfóides. As células T e CD4 positivas servem como alvo para o virus durante o estágio agudo da infecção [lwatsuki et al., 1995].

Foi isolado um anticorpo monoclonal (MAb K41) que se adsorve a superfície da célula e inibe a infecção, por VCC, de várias linhagens celulares de várias espécies. Células com MAb K41 reduz o número de infecções e o tamanho do sincício. O receptor celular envolvido é o CD9, uma proteína transmembrana que torna células susceptiveis ao VCC. A CD9 é uma proteína de superfície que está presente em células $\mathrm{B}$, eosinófilos, basófilos, células $T$ ativas e várias células não hematopoiéticas e tecidos, incluindo o SNC [Löffler et al., 1997].

\subsection{Imunoprofilaxia}

Em 1923 e 1924, Puntoni demonstrou que foi possível propagar o VCC por passagens intracerebrais de cão para cão, e que foi possivel converter essa virulência através de um tratamento por vacina. O primeiro método de vacinação de Puntoni foi administrar, primeiro, uma dose do vírus morto, subcutaneamente, depois uma dose com vírus atenuado e, para completar a imunização e confirmar a imunidade, administrou-se uma pequena dose de material contaminado. Concluiu-se que a imunização com a vacina, com vírus morto ou inativado, teve bons resultados [Laidlaw and Dunkin, 1928].

Estudos feitos com vacina do sarampo para proteger cães contra cinomose, mostraram que alguns animais, depois de imunizados, foram expostos ao VCC, 
tendo uma produção de anticorpos. O oposto ocorreu com alguns cães, que não haviam sido imunizados com a vacina do sarampo, e apresentaram VCC no baço, sem produção de anticorpos [Baker, 1970].

Em geral, os cães, podem ser protegidos da infecção causada pelo VCC, pela vacina atenuada viva. Contudo, tem sido observado o aumento de falhas vacinais, em filhotes, em áreas urbanas e canis, apesar da vacinação. A falha aparente, em vacinação, é considerar a presença de anticorpo materno que interfere com o vírus vacinal [Kai et al., 1993].

É comum, na prática, em muitos países, vacinar filhotes com o VS vivo modificado para protegê-los contra o VCC, isso porque as 2 viroses são antigenicamente semelhantes e o VS não é neutralizado pelos anticorpos maternos para cinomose. Essa aproximação "heterotípica" para vacinação tem sido adaptada pelos criadores que costumam vacinar seus filhotes com 6 semanas de idade, e muitos cães, ainda, possuem altos níveis de anticorpo materno, interferindo com a vacina contra o VCC. O envelope desses vírus contém 2 antígenos principais de superfície, chamados hemaglutinina $(H)$ e fusão $(F)$, ambos sendo alvo para mecanismo imune de defesa. Utilizando anticorpos monoclonais contra as várias proteínas dos Morbilivírus, Sheshberaderan et al. (1986), demonstraram que as proteínas $\mathrm{F}$ de ambos os vírus têm um alto nível de homologia entre os epítopos. A função primária da proteína $F$ é facilitar a expansão do vírus de célula para célula, um processo importante para a patogenia da doença. Em contraste, a não homologia entre os epítopos foi observada entre as proteínas $\mathrm{H}$ dos 2 virus. Appel et al. (1984), propuseram que a proteína $\mathrm{F}$ do VS seja, primariamente, a responsável pela proteção em cães, baseado na resposta imunológica observada em animais vacinados com esse vírus. Não é comum, na prática, vacinar filhotes com 6 semanas de idade contra cinomose canina, isso porque a maioria dos cães, ainda, possuem anticorpo materno que poderia neutralizar o vírus vacinal. O VS não é neutralizado pelo anticorpo contra cinomose, por isso são vacinados com esse vírus vivo modificado que induz a um estado de resistência maior do que a imunidade passiva adquirida, em grande parte, pelo colostro. Com 12 semanas de idade, o filhote, então, é imunizado com 
vacina do vírus da cinomose. Contudo, o perigo de se usar a vacina do sarampo constantemente, para proteger cães pela vacinação "heterotípica" é que a progênie de cadelas vacinadas com VS pode possuir anticorpos maternos que possam interferir com a vacinação em uma idade prematura. Torney et al. (1967), demonstraram que cadelas com o tipo selvagem do vírus da cinomose, durante a gravidez, aumentaram o título de anticorpos para sarampo, provavelmente, como conseqüência de anticorpo da proteína $F$. Como resultado, o problema original do anticorpo materno interferindo com o VCC vivo, é agora, diretamente contra o VS [Chalmers et al., 1994].

O VCC reapareceu, em cães, na Finlândia, em 1990, depois de 16 anos de ausência. Em 1994 e 1995, ocorreu uma eclosão, em áreas, com uma alta densidade populacional de cães, envolvendo animais vacinados contra cinomose. A estimativa total do número de casos foi, pelo menos, 5000, sendo que 865 casos foram confirmados pelo teste de anticorpo fluorescente indireto de 3649 amostras de células epiteliais. Dos casos confirmados, $73 \%$ apresentavam entre 3 e 24 meses de idade; 487 destes haviam sido vacinados, pelo menos uma vez e $41 \%$ apresentava uma estória completa de vacinação. O decréscimo na proporção de cães jovens com títulos de anticorpo $(<1 / 8)$ coincidiu com o declínio e o fim da eclosão durante a primavera e verão de 1995. Foi concluído que o decréscimo da imunidade populacional durante 1990 a 1994 foi o maior motivo da eclosão no verão de 1994 [Ek-Kommonen et al., 1997].

A severidade da doença tem se reduzido, constantemente, nas recentes décadas, o que pode ser atribuído ao extensivo uso de vacinas atenuadas e tratamento com antibiótico, controlando infecções bacterianas secundárias [Blixenkrone-Moller, 1989]. A doença tem sido controlada, por muitos anos, utilizando-se vacinas atenuadas vivas [Mori et al., 1994].

Estudos confirmaram que $3 \%$ do anticorpo materno transferido ocorre no útero e $97 \%$ pelo colostro, resultando em um título inicial, para recém-nascidos, igual a $77 \%$, o mesmo da cadela. Os anticorpos maternos estão, geralmente, ausentes por volta da $12^{\text {a }}$ a $14^{\text {a }}$ semanas de idade. As vacinas para VCC são, geralmente, aplicadas por volta da $3^{\mathrm{a}}$ ou $4^{\mathrm{a}}$ semanas, entre $6^{\mathrm{a}}$ a $16^{\mathrm{a}}$ semanas de 
idade, em filhotes que receberam colostro. Depois do restabelecimento por infecção natural ou auxílio por vacinação, a imunidade pode persistir por anos. A vacinação com vírus atenuado parece proteger, previamente, cães não vacinados, quando esta é aplicada pelo menos 2 dias antes da exposição ao VCC virulento. A vacina com VCC inativado não produz imunidade suficiente para prevenir a doença, mas cães vacinados mostraram uma boa resposta imune comparados aos não vacinados. Apesar do sucesso com vacinação na proteção de cães contra - VCC, a imunidade induzida vacinal nunca é tão longa quanto a resposta imune que ocorre depois da infecção natural ou experimental com vírus virulento, infecções experimentais de cães com o VS, os protege de infecções subseqüentes com VCC. O vírus vacinal do sarampo produz uma infecção não contagiosa no sistema linfóide dos cães, semelhante ao VCC vacinal. Cães com menos de 6 semanas de idade, com alta concentração de anticorpo materno não respondem bem à vacinação com VCC ou sarampo. Durante uma série de vacinação, é aconselhável se fazer uma combinação com VCC vacinal para produção adequada da imunidade, de pelo menos 12 meses de duração. Para um controle adequado, é aconselhável separar cães infectados de sadios, pois os primeiros, geralmente, eliminam o vírus em secreções por 1 a 2 semanas após a doença sistêmica aguda. Aqueles que desenvolvem sinais neurológicos, sem doença sistêmica, também, podem eliminar o vírus [Greene \& Appel, 1998].

\subsection{Diagnóstico laboratorial}

O diagnóstico definitivo de VCC é realizado pela demonstração típica de corpúsculos de inclusões virais. Estas inclusões podem estar no núcleo ou citoplasma de certas células em animais infectados com VCC. Os corpúsculos de inclusões virais podem ser observados em células do epitélio de pulmão, rim [Reculard \& Guillon, 1967]; pâncreas, estômago e bexiga urinária, também no cérebro e olhos, utilizando as técnicas de imunofluorescência ou imunocitoquímica [Appel, 1987; Greene \& Appel, 1990; Moller, 1993]. 
A demonstração de corpúsculos de inclusões intracelular em células epiteliais da conjuntiva e células do sangue, quando observadas em conjunto com sintomas clínicos típicos, caracterizam o diagnóstico "ante-mortem" . O diagnóstico "post-mortem" é baseado na característica das lesões histopatológicas, incluindo a presença de inclusões virais intranuclear e intracitoplásmica em células epiteliais da pele, trato gastrointestinal, epitélio brônquico [Bush et al., 1976]; tubular, bexiga urinária e olhos, dependendo do estágio e severidade da infecção [Alleman et al., 1992].

\subsubsection{Diagnóstico direto}

O VCC tem um tropismo por linfócitos, mas pode ser cultivado em culturas, primária ou contínua, de células de rim de cão ou furão, células de rim de macaco verde africano (Vero) e linhagem celular de linfócito B de sagüi (B95), sendo que relatos indicaram uma alta susceptibilidade dessa linhagem celular para isolamento do vírus selvagem do sarampo [Buxton et al., 1977; Hirayama et al., 1985; Kai et al., 1993]. O isolamento do VCC virulento tem-se mostrado difícil em cultura de células de rotina. A replicação viral ocorre durante a cultivação direta de tecidos alvo do hospedeiro infectado. Culturas de macrófago alveolar detecta o vírus em 24-48 horas, Formação de células gigantes (sincícios), um efeito citopático característico do VCC em muitas culturas de tecido, é detectado dentro de 2 a 5 dias, essas células sinciciais tem sido encontradas, em cães, com encefalite causada pelo VCC [Palmer et al., 1990]. Culturas de macrófagos tem, ultimamente, sido substituídas por culturas de linfócito de cão para isolamento do VCC; entretanto, a taxa de sucesso é baixa. Em geral, títulos de vírus vacinal são altos em macrófagos, linfócitos, epitélio tubular e linhagem de célula epitelial, ao passo que, cepas selvagens virulentas crescem, preferencialmente, em macrófagos e linfócitos. As culturas podem ser examinadas, com anticorpo fluorescente, quando o efeito citopático não for observado [Greene \& Appel, 1998]. Em casos agudos da doença, o epitélio brônquico demonstra formação de sincício 
dentro de 12-24 horas. Em casos agudo e subagudo, pode-se isolar o vírus em linfonodos, baço e células do timo [Appel, 1987].

Técnicas de imunofluorescência podem facilitar um diagnóstico específico para VCC, entretanto, estes testes requerem equipamento especial e são, geralmente, manuseados por laboratórios de diagnóstico regional. Em cães afetados, a imunofluorescência é, geralmente, feita em preparados citológicos da conjuntiva, tonsila e sistema respiratório. Essa técnica pode, também, ser utilizada no preparo de células do fluído, sedimento da urina e medula óssea. Sinais clínicos tornam-se aparentes em pouco tempo (14 dias), resultados positivos não seriam identificados, exceto em cães que não conseguiram uma resposta imune adequada e sucumbir a infecção. Começando com o período de restabelecimento, o anticorpo pode se adsorver e infundir o antígeno em células infectadas, conseqüentemente, resultados falso-negativos serão obtidos. $O$ vírus pode, às vezes, ser detectado por longos períodos, em células epiteliais e macrófagos do trato respiratório posterior. $O$ vírus, também, persiste por períodos de mais de 60 dias na pele, tecido da úvea, coxins e SNC. Utilizando um anticorpo fluorescente direto nas células da conjuntiva, fluído ou esfregaço sanguíneo é de grande utilidade na fase aguda da doença, em casos crônicos, o anticorpo interfere com o diagnóstico de imunofluorescência, resultados falso-negativo são freqüentes com esse método. $\mathrm{O}$ antígeno viral é difícil de ser encontrado em amostras clínicas de cães com cinomose neurológica ou os que se restabelecem de sinais sistêmicos [Greene \& Appel, 1998].

De acordo com Shin et al. (1995); a tentativa de isolamento do VCC, em cultura de tecido, pode ser um caminho efetivo para determinar a infecção. Entretanto, o isolamento do vírus leva muitos dias e/ou semanas e, freqüentemente, não se obtém sucesso se o cão afetado não estiver no estágio agudo da infecção. Outros testes laboratoriais, como imunofluorescência, imunocitoquímica ou deteç̧ão de corpúsculos de inclusões, também produzem um resultado negativo em casos subagudo ou crônico. Então, para uma análise alternativa, rápida.e sensível requerer-se, ainda, para diagnóstico laboratorial, cães suspeitos clinicamente de infecção pelo vírus. 
A forma não inflamatória de encefalite, causada pelo VCC, foi caracterizada por desmielinização em sítios de preferência, como o cerebelo, úvea e medula espinhal. O diagnóstico foi confirmado pela detecção do VCC por imunocitoquímica e por hibridização "in situ". O diagnóstico ante-mortem, em 18\% dos cães que sobreviveram, foi realizado em células do fluído cérebro- espinhal, usando anticorpo fluorescente indireto. Foram observadas mioclonias em $43 \%$ dos cães com encefalite, causada pelo VCC, sendo que, em 33\% dos cães com a forma inflamatória de encefalite estava envolvida a medula espinhal [Tipold, 1995].

\subsubsection{Diagnóstico indireto}

Uma grande variedade de técnicas imunológicas tem sido introduzida durante os últimos anos. Muitas dessas técnicas foram aplicadas para auxiliar a realização de diagnósticos na área vaterinária, mas ainda não são utilizados como rotina [Schultz \& Adams, 1978; Greene \& Appel, 1990].

Anormalidades são detectáveis, em cães, com sinais neurológicos de cinomose, entretanto, resultados falso-negativo pode ocorrer. O fluído pode crescer mais que o normal por causa da pressão intracranial causada pela inflamação. O aumento de proteína (lgG) e células, com predominância de linfócitos, tem sido característica de formas inflamatórias de encefalomielite, causada por VCC, isso porque o anticorpo é produzido localmente e este aumento não tem sido observado, em cães, vacinados ou em cães com cinomose sistêmica, sem doença no SNC. Cães com encefalomielite desmielinizante não inflamatória aguda pode ter o fluído normal [Greene \& Appel, 1990; Greene \& Appel, 1998].

O anticorpo IgM pode ser detectado em amostras de soro de cães que manifestam a doença, utilizando um ensaio imunoenzimático (ELISA). Também a detecção do antigeno viral pode ser realizada pelo método de imunofluorescência indireta, sendo que, a maioria dos casos diagnosticados, estão entre cães não vacinados e cães com relato de vacinação desconhecida. Entretanto, muitos 
casos clínicos foram, também, diagnosticados em cães vacinados [BlixenkroneMoller et al., 1993].

Foi feito um estudo para demonstrar a resposta imune em cães vacinados, usando o método de ensaio imunoenzimático (ELISA). Este método foi desenvolvido e testado para análise de anticorpo IgG contra o VCC, em filhotes e comparado com um teste padrão, o de neutralização. Nesse estudo, foram avaliadas 10 ninhadas de 4 filhotes, sendo que $16 \%$ dos filhotes foram imunizados com uma vacina viva modificada, protegidos com sucesso contra o VCC, com 6 semanas de idade. Um filhote permaneceu soro-negativo após a vacinação, com 6 e 9 semanas de idade. Este é o primeiro relato de resposta à vacinação de filhotes, usando um "Kit" baseado em um ensaio imunoenzimático [Waner et al., 1998].

A sorologia clássica para determinar a infecção causada pelo VCC proporciona dados de valores diagnóstico e prognóstico (cinética de soroconversão) e é, também, usada para predizer a idade ótima para vacinação de filhotes. A sorologia de rotina está, ainda, baseada no ensaio de neutralização do vírus. Foi demonstrada uma nova técnica de ensaio imunoenzimático do tipo, "capture-sandwich" (ELISA), que usa a proteína do nucleocapsídeo (N) expressada em baculovírus recombinante de um tipo selvagem isolado recentemente (2544/Han 95), para deteç̧ão de anticorpos específicos para VCC, em soro canino [von Messling et al., 1999].

Foi realizado um estudo utilizando um ensaio "dot-blot" para detecção de anticorpos da classe IgM contra o VCC em soro canino. O diagnóstico foi avaliado pela análise do soro de 3 grupos testados: cães experimentalmente infectados com o VCC virulento, os quais mostraram niveis detectáveis de IgM específicos para VCC; cães imunizados com uma vacina combinada contendo VCC, os quais foram, também, positivos para IgM anti-VCC após a primeira imunização; e cães imunizados com uma vacina livre de VCC, como antígeno para o ensaio, utilizando a proteína do nucleocapsídeo $(\mathrm{N})$ recombinante da cepa virulenta (A75/17), os quais permaneceram negativos no decorrer do experimento. A partir desses resultados, concluiu-se que, a detecção do anticorpo IgM requer somente uma 
amostra de soro e é um método de diagnóstico útil para determinar infecção recente ou generalizada pelo VCC, em cães experimentalmente infectados ou imunizados [Barben et al., 1999].

\subsubsection{Diagnóstico Molecular}

A técnica da Reação em Cadeia pela Polimerase (PCR) tem sido utilizada para o diagnóstico de muitas doenças infecciosas virais. Essa metodologia consiste na amplificação de seqüências específicas de DNA, o que confere maior sensibilidade na detecção de vários agentes virais, em materiais clínicos [Bellini et al., 1986; Haas et al., 1991; Rota et al., 1995]. Shimizu et al. (1994), padronizou uma reação de RT-PCR para detecção de Morbilivírus. Nesse estudo, os autores, desenharam e otimizaram "primers" que amplificam uma região conservada para o gene da nucleoproteína, para detecção de diferentes Morbilivírus: VS, VPB e VCC.

Em 1995, foi realizado um estudo para a determinação de um método de diagnóstico rápido de infecção, pelo VCC. A reação de RT-PCR foi efetuada para detectar o gene da nucleoproteína desse vírus, em células mononucleares do sangue periférico. Duas séries de iniciadores "primers" foram alvo para 2 regiões do gene NP da cepa "Onderstepoort". Os fragmentos desse gene foram bem amplificados pela reação de RT-PCR. O amplificado do gene NP foi detectado em 17 de 32 amostras de cães, que eram clinicamente suspeitos de infecção por VCC, em hospitais veterinários. Nenhum produto de RT-PCR foi encontrado em 52 amostras de cães saudáveis, incluindo 40 beagles vacinados, livres do patógeno específico, com uma vacina com vírus vivo atenuado para VCC. Assim conclui-se que a reação de RT-PCR proporciona um método seguro, sensível e suplementar para o diagnóstico da infecção em cães [Shin et al., 1995].

Recentemente, infecções de outros Morbilivírus foram determinadas pela RT-PCR. Em um dos estudos, foi determinada, por essa técnica, a presença do gene da nucleoproteína em células mononucleares do sangue periférico de cães infectados com VCC. Para determinar a sensibilidade do método de PCR, foram feitas diluições do gene da NP da cepa "Onderstepoort" e das células Vero 
infectadas com VCC, sendo ambas amplificadas. Os resultados mostraram que 200 cópias de DNA ou 1 célula infectada eram suficientes para detectar produto amplificado por hibridização "Southern blot". Esses resultados indicaram que uma única célula infectada, em que o VCC foi replicado, poderia ser detectada pelo método de RT-PCR. Nenhuma correlação entre os resultados dessa técnica e títulos de anticorpos neutralizantes foi observada [Shin et al., 1995].

Análises de fragmentos de restrição foram usados para diferenciar tipos recentes do VCC de cepas vacinais. O genoma do virus foi amplificado usando a RT-PCR para a proteína hemaglutinina. O produto de PCR do recente isolado foi cortado em 2 fragmentos que diferem da forma completa de cepas mais antigas, incluindo todas as cepas vacinais. Este método poderia ser aplicado em cérebro, baço e células mononucleares do sangue periférico de cães infectados. Essa pesquisa molecular é útil para determinar o agente causador da infecção pósvacinal causada pelo VCC [Ohashi et al., 1998].

Dados na literatura mostram-nos a inexistência de estudos mais completos relatando a excreção viral em animais doentes. Rota et al. (1995), utilizaram a técnica de RT-PCR para definir a freqüência de excreção viral na urina de crianças, obtida após a vacinação contra o VS, sugerindo a utilidade desse método, tanto para o diagnóstico de casos assintomáticos de sarampo, como para estudos de transmissão viral. Lima (1999), avaliou e quantificou a excreção viral em linfócito, urina e saliva provenientes de crianças vacinadas contra o sarampo, utilizando o método de RT-PCR para RNA do mesmo, concluindo ser a saliva o espécime clínico de maior positividade na detecção do RNA viral, seguido pela urina e linfócitos, embora tenha encontrado excreção viral por períodos longos após a vacinação, em linfócitos.

O presente estudo, avaliando a excreção do VCC, por diferentes vias, em cães com sintomatologia clínica sugestiva de cinomose, poderá trazer uma contribuição relevante para maior compreensão da patogênese dessa virose. 
2. OBJETIVOS 


\section{OBJETIVOS}

- Padronizar a técnica de RT-PCR para deteç̧ão do vírus da cinomose canina, a partir de materiais clínicos de cães suspeitos da doença.

- Verificar, através da técnica de RT-PCR, a presença do RNA viral no sangue circulante, analisando linfócitos, urina e saliva de animais com diagnóstico clínico de cinomose. 


\section{MATERIAIS E MÉTODOS}




\section{MATERIAIS E MÉTODOS}

\subsection{Amostras clínicas}

Foram analisadas espécimes clínicas provenientes de 100 cães examinados no Hospital Veterinário da Universidade de São Paulo (HOVET).

As amostras de sangue, urina e saliva foram colheitadas sob a responsabilidade das Doutoras: Marcia Mery Kogika, Vera A. Batistini Fortunato e Bruna Maria Pereira Coelho, como mostram a tabela 1 e o anexo 1.

Tabela 1- Número de espécimes clínicas colheitadas (sangue, urina e saliva) de 100 animais, provenientes do HOVET, com sintomatologia sugestiva de cinomose.

\begin{tabular}{|l|c|l|}
\hline Amostra & Total & \multicolumn{1}{l|}{ Porcentagem } \\
\hline Sangue, urina e saliva & 80 & $80 \%$ \\
\hline Sangue e saliva & 18 & $18 \%$ \\
\hline Sangue & 2 & $2 \%$ \\
\hline Total & 100 & $100 \%$ \\
\hline
\end{tabular}

As amostras foram colheitadas durante o período de 25 de agosto de 1997 a 28 de outubro de 1998. Cada cão que chegava ao Hospital Veterinário passava pela triagem e era encaminhado ao ambulatório para coleta de sangue, urina e saliva para posterior estudo. Foram colheitadas amostras clínicas de cães de idade e raça distintas, tendo como critério os seguintes sintomas: febre, conjuntivite, sintoma respiratório, diarréia, hiperqueratose dos coxins e focinho, anorexia, incontinência motora, mioclonias e convulsão. A colheita das amostras distribuídas dentro do período de um ano foi feita com o objetivo de observar-se a regressão ou evolução dos sintomas de cada cão, fazendo um acompanhamento clínico.

Essas amostras eram mantidas a $4^{\circ} \mathrm{C}$, durante o transporte ao laboratório, e eram processadas no mesmo dia, sendo os soros estocados a $-20^{\circ} \mathrm{C}$ para 
posterior estudo sorológico, sendo o restante das amostras estocadas a $-70^{\circ} \mathrm{C}$, até o início da extraçăo do RNA.

As amostras de sangue foram colheitadas através de punção venosa ( 5 $\mathrm{mL}$ ), utilizando-se tubos de vidro novos com anti-coagulante (heparina) e tampa de borracha, evitando assim, problemas de contaminação das amostras, durante o processamento das mesmas.

As amostras da primeira urina foram colheitadas, utilizando-se sondas uretrais estéreis de tamanho proporcional ao porte do animal e colocadas em tubos de plástico estéreis de $15,0 \mathrm{~mL}$, com tampa de rosca.

As amostras de saliva foram colheitadas da cavidade oral, com o auxílio de uma zaragatoa e colocadas em tubos de microcentrifuga (eppendorfs) contendo $500 \mu \mathrm{L}$ de solução salina tamponada com fosfato $0,01 \mathrm{M}, \mathrm{pH} 7.2$ (PBS) estéril.

\subsection{Processamento das amostras para o PCR}

\subsubsection{Sangue venoso total, para obtenção de soro}

Após retração do coágulo e separação, por centrifugação, a uma rotação de $2000 \times \mathrm{g}$ durante 10 minutos, as amostras de soro foram aliquotadas em "eppendorfs" novos e estocadas a $-20^{\circ} \mathrm{C}$, até a realização das técnicas de Imunofluorescência Indireta, para deteç̧ão de anticorpos específicos ao vírus da cinomose, para posterior estudo.

\subsubsection{Linfócitos}

As células mononucleares (linfócitos) foram separadas do sangue venoso heparinizado, por sedimentação, utilizando Ficcol Hypaque (Organon Teknika). Os tubos de sangue com anti-coagulante eram abertos em um fluxo laminar, após assepsia e esterilização do mesmo, para evitar possivel contaminação. Acrescentava-se PBS para diluir 0 sangue (volume/volume). Após homogeneização, esse sangue era passado no Ficcol, vagarosamente, para evitar 
refluxo; ao término, os tubos eram fechados e centrifugados a uma rotação de $1250 \times$ g, durante 30 minutos. O Ficcol, junto com o plasma, eram desprezados e era feita a colheita do anel de linfócitos. Esse anel de linfócitos era colocado em um outro tubo de plástico estéril e acrescentava-se PBS para lavagem das células, centrifugando-se a uma rotação de $1200 \times \mathrm{g}$, durante 10 minutos. O sobrenadante era desprezado e o anel ressuspenso com novo PBS, sendo feitas 3 lavagens nas células, para exclusão total do Ficcol. Após essa fase, o botão de células foi ressuspenso com $1,0 \mathrm{~mL}$ de meio RPMI 1640 estéril, sendo que $500 \mu \mathrm{L}$ dessas células foram guardadas em tubos Nalgene, com tampa de rosca, acrescentandose uma solução de estocagem de $500 \mu \mathrm{L}$ de glicerina e soro fetal bovino (SFB), na proporção de 1:10, para conservação da membrana celular. Aos outros $500 \mu \mathrm{L}$ de células, foram adicionados $500 \mu \mathrm{L}$ de Trizol (Gibco-BRL), volume a volume, estocando-os a $-70^{\circ} \mathrm{C}$, até o momento da extração do RNA. As células com a solução de estocagem foram guardadas em tambores com nitrogênio líquido, para melhor conservação das partículas virais.

\subsubsection{Urina}

Depois de colhidas, as amostras de urina foram mantidas a $4^{\circ} \mathrm{C}$, até $\mathrm{o}$ momento do transporte ao laboratório. Foram centrifugadas a $2600 \mathrm{x} \mathrm{g}$, durante 10 minutos, a $4^{\circ} \mathrm{C}$, o sobrenadante desprezado, e o sedimento lavado uma vez, com PBS, a uma rotação de $2600 \times$ g, durante 10 minutos. Novamente, o sobrenadante foi desprezado e o sedimento ressuspenso em $500 \mu \mathrm{L}$ de Trizol, sendo estocadas a $-70^{\circ} \mathrm{C}$, até o início da extração do RNA.

\subsubsection{Saliva}

Depois de colhidas, as amostras de saliva foram mantidas a $4^{\circ} \mathrm{C}$, até serem transportadas ao laboratório. Posteriormente, foram adicionados $500 \mu \mathrm{L}$ de Trizol e congeladas a $-70^{\circ} \mathrm{C}$, até momento de uso (para PCR). Todo esse manuseio, com todas as amostras, foi feito no fluxo laminar, evitando-se possíveis contaminações. 


\subsubsection{Preparo das amostras para PCR}

Para evitar resultados falso-positivos, através da contaminação pelo produto amplificado, o espaço físico do laboratório foi totalmente remodelado, com a utilização de 2 fluxos laminares apropriados, um para extração do ácido nucleico e outro para o preparo da reação de PCR, sendo um terceiro fluxo laminar destinado a uma outra área de serviço para manipulação do produto amplificado (pós-PCR). Para cada espaço físico, foi utilizado um jogo de pipetas automáticas, minimizando, desta forma, a contaminação entre os 3 ambientes.

Foi estabelecido, também, o critério de se processar 10 amostras de cada vez, mais 2 amostras de controle, sendo um controle negativo e o outro positivo. Como controle negativo, foi utilizada água altamente purificada (Sistema Milli-Q, Millipore), isenta de inibidores que poderiam impedir a amplificação de produtos contaminantes de PCR. O controle positivo consistiu de uma cepa selvagem do vírus da cinomose, adaptada em células B 95, gentilmente cedida pelo Dr. Paul Rota, do Center for Disease Control and Prevention-CDC, Atlanta-Georgia, USA.

\subsection{Reação de PCR}

\subsubsection{Extração}

Após descongelamento das amostras com Trizol, procedeu-se a continuidade da extração de RNA, feita em banho de gelo, de acordo com o protocolo descrito a seguir:

Foram colocados $500 \mu \mathrm{L}$ do material (linfócito, urina ou saliva) em um "eppendorf" e acrescentou-se $500 \mu \mathrm{L}$ de Trizol. Foram adicionados $200 \mu \mathrm{L}$ de clorofórmio-isoamil e, após homogeneização em agitação durante 15 segundos, incubou-se em gelo, por 5 minutos, sendo centrifugados a uma rotação de $12000 \mathrm{x}$ g a $4^{\circ} \mathrm{C}$, durante 15 minutos. Após centrifugação, o sobrenadante obtido da fase superior foi coletado e precipitado, volume a volume, com isopropanol e incubado 
em gelo durante 15 minutos. A mistura, novamente centrifugada a $12000 \times \mathrm{g}$, durante 15 minutos, o sobrenadante desprezado e o sedimento lavado com $800 \mu \mathrm{L}$ de etanol $(75 \%)$. O sedimento, agitado vigorosamente e centrifugado a $7500 \times \mathrm{g}$, a $4^{\circ} \mathrm{C}$, por 8 minutos, desprezando-se o sobrenadante. Finalmente, 0 sedimento foi seco e dissolvido em $30 \mu \mathrm{L}$ de EDTA $1 \mathrm{mM}, \mathrm{pH} 7,0$. A extração foi guardada em freezer, a $-70^{\circ} \mathrm{C}$.

O mesmo procedimento foi realizado com a célula B95 infectada com o vírus padrão.

\subsection{2. "Primers"}

Para a detecção do genoma do VCC, foram usados os iniciadores "primers" que se ligam à região altamente conservada, entre as bases 746 e 1082 que codificam o gene nucleoproteína, segundo a metodologia descrita por Shimizu et al. (1994); com algumas modificações, referentes aos "primers" RMBV1 e RMBV32, que foram re-delineados para se adequar as seqüências do VCC.

Foram utilizados os "primers" RMBV1 e RMBV3, RMBV2 e RMBV32 na região $5^{\prime}$ durante a síntese, com a seguinte seqüência:

\begin{tabular}{|c|c|c|c|c|}
\hline & "Primers" & Locaçăo (RNA) & Sequência "Primers" & $\begin{array}{l}\text { Produto } \\
\text { Amplificado }\end{array}$ \\
\hline PCR & $\begin{array}{l}\text { RMBV1 } \\
\text { RMBV3 }\end{array}$ & $\begin{array}{l}(1167-1189) \\
(853-875)\end{array}$ & $\begin{array}{l}\text { AAGCTGGGTCAAAGTAAGATCG } \\
\text { GAATTGCTGAAATGATTTGTGAT }\end{array}$ & $336 \mathrm{pb}$ \\
\hline $\begin{array}{l}\text { Nested- } \\
\text { PCR }\end{array}$ & $\begin{array}{l}\text { RMBV2 } \\
\text { RMBV32 }\end{array}$ & $\begin{array}{l}(930-952) \\
(1145-1164)\end{array}$ & $\begin{array}{l}\text { TTTGGCATTGAAACTATGTATCC } \\
\text { CGAAACCCAACCCTCCCATG }\end{array}$ & $234 \mathrm{pb}$ \\
\hline
\end{tabular}




\subsection{3. cDNA}

A partir do RNA extraído foi feito um CDNA, utilizando Transcriptase Reversa na seguinte mistura da reação: $20,0 \mu \mathrm{L}$ de tampão $2 x$ concentrado, $1,0 \mu \mathrm{L}$

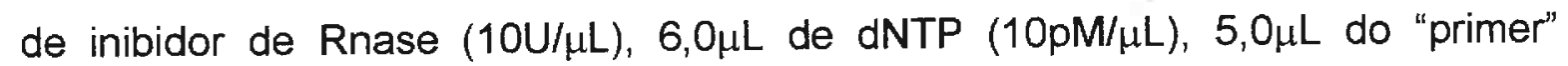
RMBV1 $(10 \mathrm{pM} / \mu \mathrm{L}), 1,0 \mu \mathrm{L}$ de Transcriptase Reversa $(200 \mathrm{U} / \mu \mathrm{L}), 4,0 \mu \mathrm{L}$ de DTT (detergente-0,1M) e 5,0 $\mu \mathrm{L}$ do RNA extraido. Distribuiu-se $42,0 \mu \mathrm{L}$ do preparo em cada "eppendorf" e acrescentou-se os 5,0 $\mathrm{L}$ da respectiva amostra.

A mistura da reação foi incubada por 60 minutos a $42^{\circ} \mathrm{C}$ e guardada em freezer a $-70^{\circ} \mathrm{C}$.

\subsubsection{Amplificação do cDNA (PCR)}

Para reação de PCR fez-se a seguinte mistura: $50,5 \mu \mathrm{L}$ de $\mathrm{H}_{2} \mathrm{O}$ Milli-Q

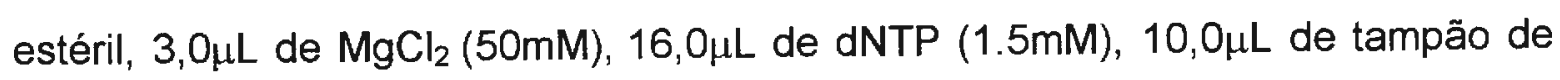
PCR 10x concentrado, 5,0 $\mu \mathrm{L}$ do "primer" RMBV1, 5,0 $\mu \mathrm{L}$ do "primer" RMBV3, 0,5 $\mu \mathrm{L}$ de Taq Polimerase $(5 \mathrm{U} / \mu \mathrm{L})$ e, por último, 10,0 $\mu \mathrm{L}$ da amostra (CDNA). Acrescentouse $25,0 \mu \mathrm{L}$ de óleo mineral, para evitar possivel evaporação da amostra. Após a mistura, o material foi colocado em um Termociclador automático "M J Research" a $94^{\circ} \mathrm{C}$, por 5 minutos (para inativar a RT), seguidos de 39 ciclos de $94^{\circ} \mathrm{C}$, por 1 minuto (para denaturação das fitas de DNA); $55^{\circ} \mathrm{C}$ por 1 minuto (para anexamento, "anneling" dos "primers") e $72^{\circ} \mathrm{C}$ por 1 minuto (para extensão das fitas), seguido de $72^{\circ} \mathrm{C}$ por 5 minutos (para completar as extensões das fitas). Ao término, as amostras foram guardadas a $4^{\circ} \mathrm{C}$.

\subsubsection{Nested-PCR}

Para reação de Nested-PCR fez-se a seguinte mistura: 50,5 $\mu \mathrm{L}$ de $\mathrm{H}_{2} \mathrm{O}$ Milli-Q estéril, $3,0 \mu \mathrm{L}$ de $\mathrm{MgCl}_{2}(50 \mathrm{mM}), 16,0 \mu \mathrm{L}$ de dNTP $(1.5 \mathrm{mM}), 10,0 \mu \mathrm{L}$ de tampão de PCR $10 x$ concentrado, 5,0 $\mu \mathrm{L}$ do "primer" RMBV2, 5,0 $\mu \mathrm{L}$ do "primer" 
RMBV32, $0,5 \mu \mathrm{L}$ de Taq Polimerase $(5 \mathrm{U} / \mu \mathrm{L})$ e, por último, $10,0 \mu \mathrm{L}$ da amostra (PCR). Acrescentou-se 25,0 $\mu \mathrm{L}$ de óleo mineral, para evitar possível evaporação da amostra. Após a mistura, o material foi colocado em um Termociclador automático "M J Research" a $94^{\circ} \mathrm{C}$, por 5 minutos (para inativar a RT), seguidos de 39 ciclos de $94^{\circ} \mathrm{C}$, por 1 minuto (para denaturação das fitas de RNA); $48^{\circ} \mathrm{C}$ por 1 minuto (para anexamento, "anneling" dos "primers") e $72^{\circ} \mathrm{C}$ por 1 minuto (para extensão das fitas), seguido de $72^{\circ} \mathrm{C}$ por 5 minutos (para completar as extensões das fitas). Ao término, as amostras foram estocadas a $4^{\circ} \mathrm{C}$.

\subsubsection{Visualização dos produtos amplificados de PCR e Nested-PCR}

Os produtos de PCR e Nested-PCR foram analisados em eletroforese em gel de agarose a $2 \%$, em tampão TBE (Tris Borato EDTA-Gibco BRL) 1,0x concentrado (89mM de Tris; $89 \mathrm{mM}$ de Ácido bórico; 2,0mM de $\mathrm{Na}_{2}$ EDTA, pH 8,0Gibco BRL). Adicionou-se ao tampão um corante (brometo de etídio- $10 \mathrm{mg} / \mathrm{mL}$; utilizando-se 5,0 $\mu \mathrm{L} / 100,0 \mathrm{~mL}$ do tampão) e, junto com a amostra, colocou-se o corante azul de bromofenol $(2,0 \mu \mathrm{L} / 5,0 \mu \mathrm{L}$ da amostra). A eletroforese foi realizada sob uma corrente de $100 \mathrm{~mA}$, durante, aproximadamente, 40 minutos. Em seguida, os fragmentos amplificados foram visualizados em transluminador de ultra-violeta. 
4. RESULTADOS 


\section{RESULTADOS}

Para a padronização das técnicas de PCR e Nested-PCR foi utilizado o vírus padrão da cinomose canina, inoculado em células B95. A reação de RTPCR, utilizando os "primers" RMBV1 e RMBV3, amplificou um produto de 336 bp. Quando o produto de PCR foi re-amplificado pela reação de Nested-PCR, utilizando os "primers" internos RMBV2 e RMBV32, obteve-se uma amplificação de $234 \mathrm{bp}$, como mostra a figura 1. 
Padronização da técnica de RT-PCR.

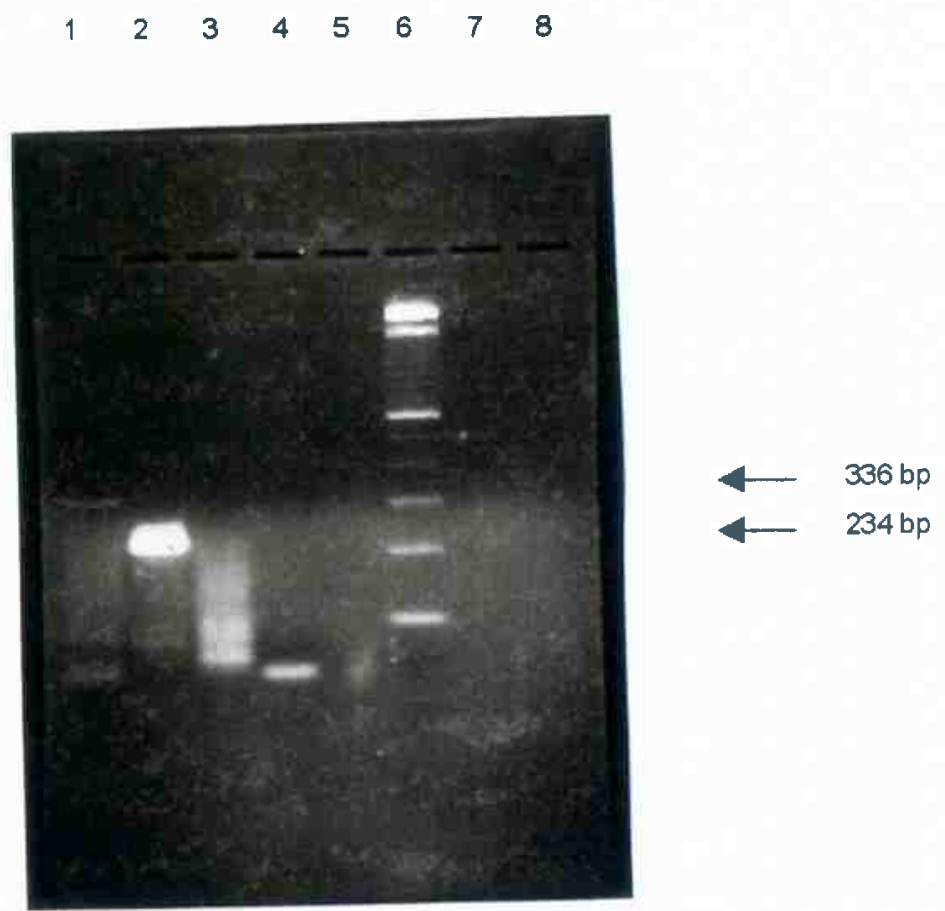

Figura 1: Detecção do produto amplificado pelas reações de RT-PCR e Nested$P C R$, em gel de agarose, corado pelo brometo de et;idio. Linha 1: produto amplificado pela reação de RT-PCR, evidenciando uma banda de $336 \mathrm{bp}$. Linha 2: produto amplificado pela reação de Nested-PCR, evidenciando uma banda de 234 bp. Linha 3: controle negativo da reação de RT-PCR, utilizando água. Linha 4: controle negativo da reação de Nested-PCR. Linha 6: marcador de peso molecular (PM). 
A figura 2 mostra o resultado da reação de Nested-PCR

de amostras positivas de linfócitos e urina, colheitadas de cães com sintomatologia clínica de cinomose canina, provenientes do HOVET.

$2627282930313233363840414546 \mathrm{C}+\mathrm{C}-\mathrm{PM}$

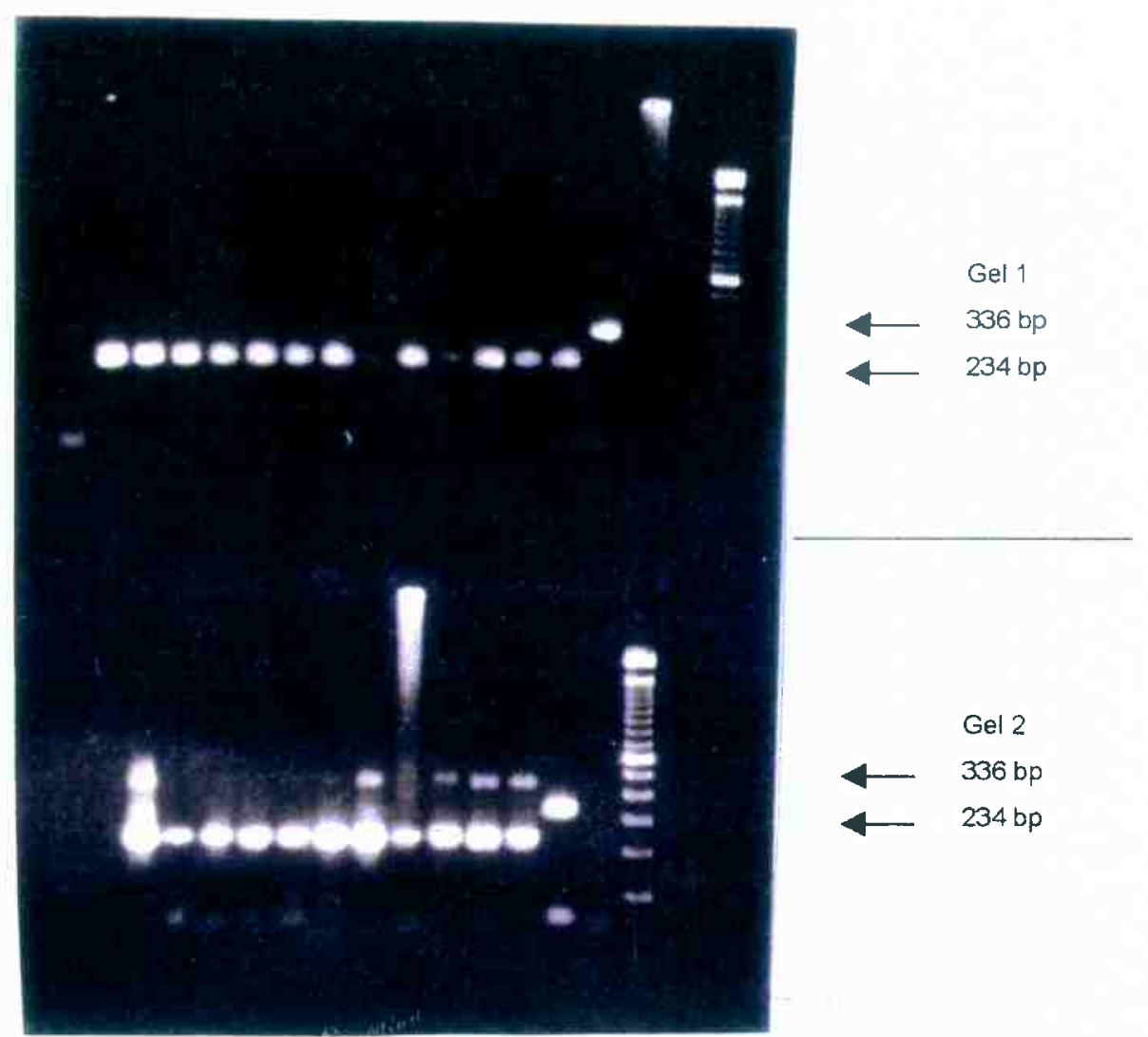

$2627282930313338404145 \mathrm{C}+\mathrm{C}$. PM

Figura 2: Deteç̧ão do produto de Nested-PCR, em gel de agarose, corado pelo brometo de etídio. Na parte superior ( $g$ el 1) são amostras de linfócitos: 26 $-27-28-29-30-31-32-33-36-38-40-41-45-46$ - controle positivo (célula B95 infectada com vírus selvagem-produto de PCR) - controle negativo (H2O) - PM (Marcador de Peso Molecular), respectivamente. Na parte inferior (gel 2) são amostras de urina: 26 - 27 - 28 - 29 - 30 - 31 - 33 - 38 - 40 - 41 - 45 controle positivo (célula B95 infectada com virus selvagem-produto de PCR) controle negativo ( $\mathrm{H} 2 \mathrm{O})$ - PM (Marcador de Peso Molecular). 


\subsection{Detecção do RNA viral em amostra clínica}

As amostras de sangue, urina e saliva, provenientes dos 100 cães estudados, foram testadas para cinomose canina, utilizando-se a técnica de RTPCR. Observou-se que 43 amostras de sangue e 49 de urina reagiram positivamente, enquanto que somente 18 foram positivas nas amostras de saliva (tabela 2, anexo 2).

Tabela 2- Resultado de PCR para diagnóstico da cinomose canina com "primers" específicos em amostras clínicas de sangue, urina e saliva de 100 cães com sintomatologia sugestiva de cinomose, atendidos no HOVET.

\begin{tabular}{|l|l|l|l|l|}
\hline Resultado/PCR sangue & urina & \multicolumn{2}{l|}{ saliva } & Total \\
\hline Positivo & 43 & 49 & 18 & 110 \\
\hline Negativo & 52 & 31 & 80 & 163 \\
\hline NR $^{\star} /$ NR $^{\star \star}$ & $05^{\star}$ & $20^{\star \star}$ & $02^{\star \star}$ & 27 \\
\hline
\end{tabular}

*NR: não realizado

**NR: não colheitado 
Da totalidade das amostras positivas (110), pela reação de Nested-PCR, 6 amostras apresentaram positividade pela reação de PCR, como mostra a figura 3 .

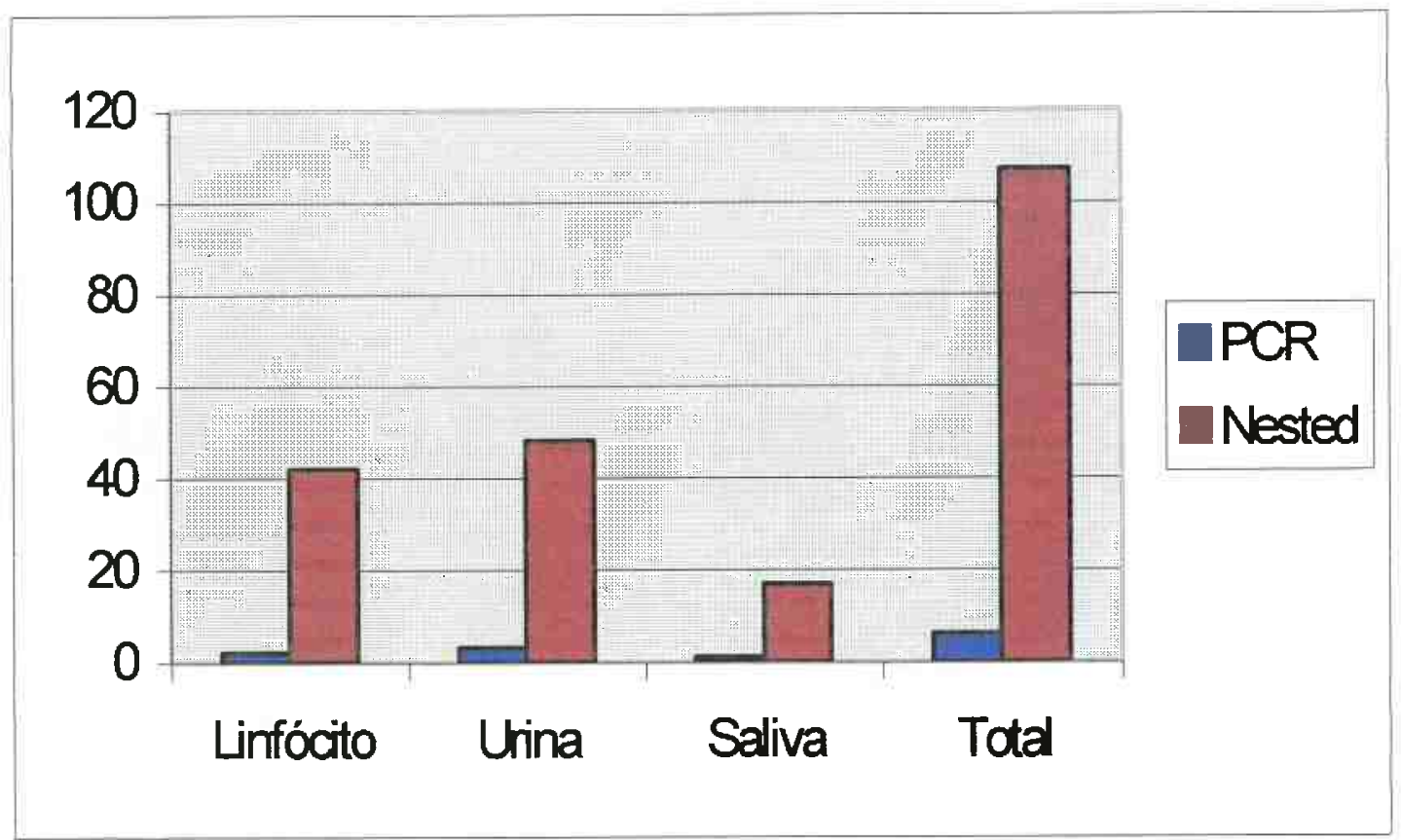

Figura 3- Comparação da reação de PCR e Nested-PCR para detecção de RNA viral em amostras clínicas (sangue, urina e saliva), provenientes dos animais estudados.

Em alguns animais foi possivel observar-se reação positiva em apenas um material biológico (sangue, urina ou saliva), enquanto em outros houve reação positiva em mais de um material biológico. 
$\mathrm{Na}$ tabela 3 e figura 4 encontram-se relacionadas as amostras positivas, segundo o material clínico, entre os animais que haviam sido vacinados.

A freqüência de reações positivas entre os animais não vacinados foi maior do que a freqüência entre os animais vacinados. Observa-se também que a porcentagem de concordância, tanto em animais vacinados quanto não vacinados, foi maior na urina e linfócito do que na saliva.

Tabela 3- Animais vacinados e não vacinados considerados positivos para detecção do RNA do VCC, pela técnica de RT-PCR.

\section{RNA Viral}

\begin{tabular}{|c|c|c|c|c|c|c|}
\hline & \multicolumn{6}{|c|}{ RNA Viral } \\
\hline \multicolumn{7}{|l|}{ Resultadol } \\
\hline \multirow{2}{*}{$\begin{array}{c}\text { Diagnóstico } \\
\text { clínico }\end{array}$} & \multicolumn{2}{|c|}{ Linfócito } & \multicolumn{2}{|c|}{ Urina } & \multicolumn{2}{|c|}{ Saliva } \\
\hline & Vac. & Não vac. & Vac. & Não vac. & Vac. & Não Vac. \\
\hline \multicolumn{7}{|l|}{ Concordantes } \\
\hline Pos/Pos & 13 & 28 & 15 & 32 & 04 & 12 \\
\hline Neg/Neg & 00 & 00 & 00 & 00 & 00 & 00 \\
\hline \multicolumn{7}{|l|}{ Discordantes } \\
\hline Pos/Neg & 05 & 12 & 03 & 08 & 14 & 28 \\
\hline Neg/Pos & 00 & 00 & 00 & 00 & 00 & 00 \\
\hline Total & 18 & 40 & 18 & 40 & 18 & 40 \\
\hline \% Concordância & $72.3 \%$ & $70.0 \%$ & $83.3 \%$ & $80.0 \%$ & $22.2 \%$ & $30.0 \%$ \\
\hline \%Discordância & $27.7 \%$ & $30.0 \%$ & $16.7 \%$ & $20.0 \%$ & $77.8 \%$ & $70.0 \%$ \\
\hline
\end{tabular}


A figura 4 representa a freqüência de animais vacinados e não vacinados pela técnica de RT-PCR.

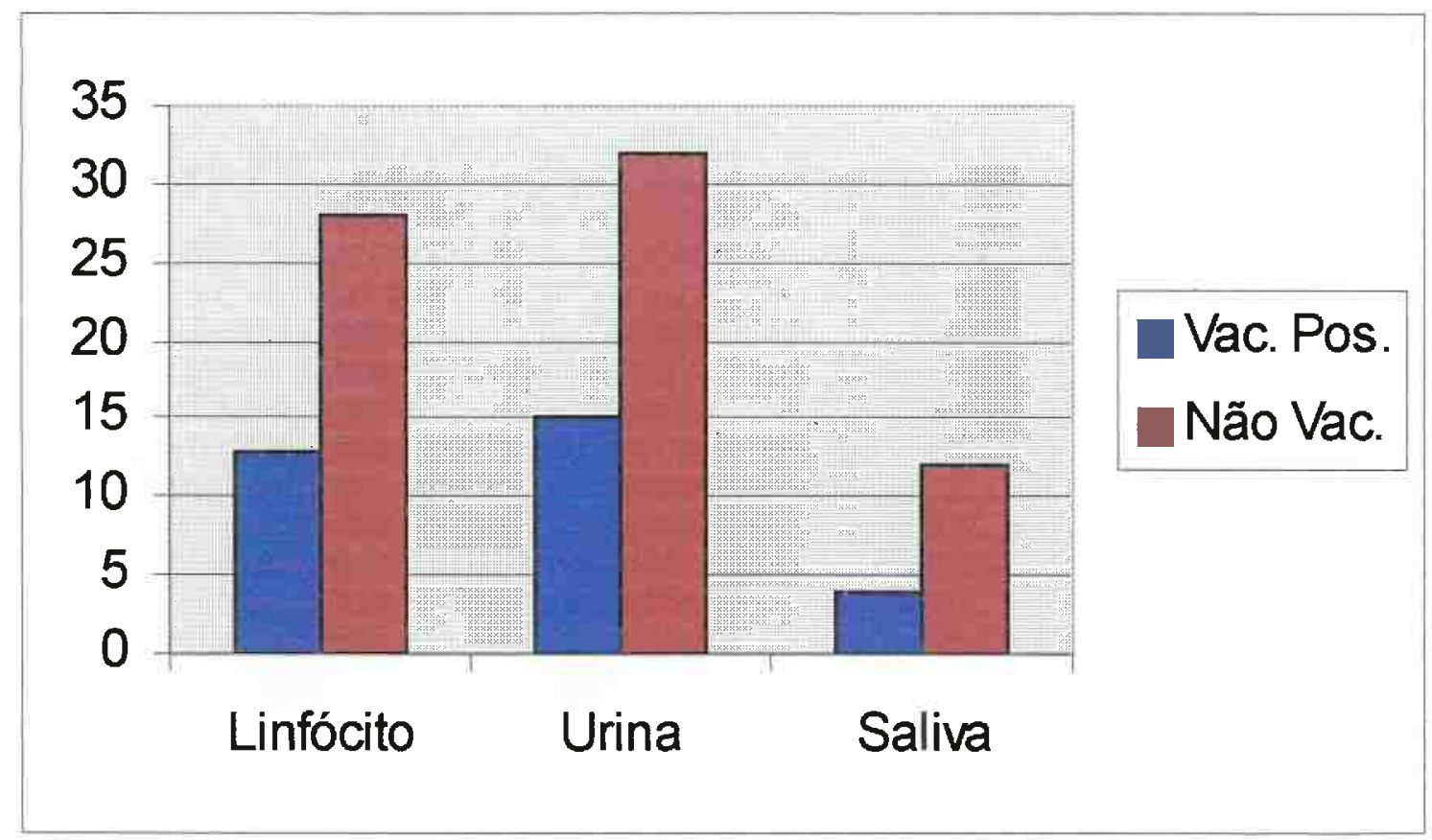

Figura 4- Freqüência de animais vacinados e não vacinados considerados positivos para detecção do RNA DO VCC pela técnica de RT-PCR. 
5. DISCUSSÃO 


\section{DISCUSSÃO}

O VCC tem causado epidemias em várias partes do mundo, em muitas espécies susceptíveis, ocasionando mortalidade e morbidade a esses animais.

A doença causada pela infeç̧ão do VCC tem sido controlada por muitos anos com o uso de vacinas com vírus vivo atenuado. Entretanto, muitos casos de cinomose canina tem ocorrido no Japão. Esse virus atua em células linfóides e a indução de imunossupressão agrava a doença, permitindo que infecções secundárias se estabeleçam. A infecção, muitas vezes, induz uma doença fatal, em cães [Mori et al., 1994; Shin et al., 1995].

No presente estudo, foi feita uma pesquisa usando a técnica de RT-PCR para diagnosticar o VCC, em cães com sintomatologia sugestiva da doença. Foram analisados 100 cães, sendo colheitadas amostras de sangue, urina e saliva, respectivamente.

Recentes avanços em detecção molecular da seqüência do ácido nucleico viral tem facilitado a pesquisa de viroses patogênicas em amostras clínicas. O desenho dos iniciadores "primers" deve ser baseado em seqüências conhecidas (regiões altamente conservadas) do genoma viral. $O$ alinhamento das seqüências para os genes da nucleoproteina e matrix sugerem uma região altamente conservada como alvo para amplificação do gene [Shimizu et al., 1994].

Em nosso estudo, foi evidenciada a presença do gene da nucleoproteina (NP) pela técnica de RT-PCR em células mononucleares do sangue periférico, urina e saliva de cães infectados, com VCC, discutindo a vantagem do método de diagnóstico. A técnica de RT-PCR descrita, neste estudo, pode ser um ensaio útil para determinar se cães suspeitos de infecção, pelo vírus, apresentam níveis detectáveis de genes NP. Os resultados demonstraram a vantagem dessa técnica para suplementar outros métodos de diagnóstico laboratorial.

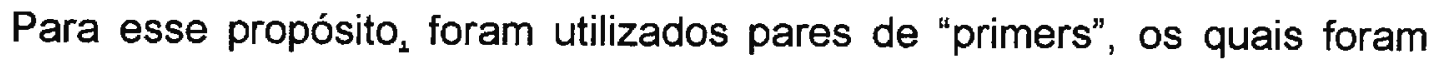
escolhidos do gene da nucleoproteína, por ser uma região altamente conservada, o qual amplificou, com sucesso, o VS, o VCC e o VCF. O método de RT-PCR estabelece um método simples, rápido e altamente sensível de detecção e 
identificação de seqüências genômicas de RNA [Saiki et al., 1988; Godec et al., 1990].

De acordo com Oglesbee et al. (1986; 1989); o isolamento do VCC, em cultura celular, poderia ser um caminho efetivo para determinar a infecção, entretanto, 0 isolamento do vírus leva muitos dias e/ou semanas. No estudo desses autores, foi possivel a identificação do gene NP usando o método de RTPCR com dois pares de "primers" específicos. Foi determinado que, pelo menos, 200 cópias do cDNA (NP) ou uma célula Vero infectada, com VCC, são necessárias para obter uma quantidade de produto amplificado. Considerando que a proteína NP é o componente mais abundante do nucleocapsídeo, do vírus, é possível que uma única célula infectada possa ser detectada pelo método de RTPCR.

Em nosso estudo, a capacidade de detecção do RNA viral em espécimes clínicos necessitou do uso de uma segunda amplificação, utilizando a técnica de Nested-PCR, a qual foi escolhida para realização deste trabalho, devido à sua alta sensibilidade e especificidade, do teste para 100 vezes mais, detectando quantidades mínima de partículas virais do VCC nos materiais analisados, RTPCR seguida pela Nested.

Nesta pesquisa, embora no histórico de vacinação não foram fornecidas as informações quanto ao tipo de vacina utilizada e o esquema de vacinação, obtivemos um total de 36 cães que foram submetidos a uma estória de vacinação, 18 animais confirmaram positividade pelo método de RT-PCR e 18 foram considerados negativos, pelo mesmo método. Dos 18 animais que apresentaram estória de vacinação; 4 deles excretaram o vírus pela urina; 3 pelo linfócito; 1 pela urina e saliva; 7 pelo linfócito e urina e 3 pelo linfócito, urina e saliva [Anexo 3]. Foi observado que os animais adoeceram ou não em função da vacina, se bem imunizados, a vacina falhou ou não foram bem imunizados. Resumindo nossas observações, cães vacinados ou não vacinados, apresentaram positividade pela técnica de RT-PCR, como também, cães vacinados apresentaram negatividade pela mesma técnica. É provável, já que os animais são todos sintomáticos, que tenham adquirido ą infecção natural, por serem, ainda, susceptíveis, a despeito da 
menção de terem sido vacinados. Uma vez que o número de animais considerados positivos foi menor no grupo de vacinados, o que pode significar infecção mais branda, devido a imunidade parcial.

De acordo com o trabalho de Shin et al. (1995); a possibilidade de detectar vírus vacinal, em amostras clínicas, é considerado pequena, porque foram obtidas amostras de 3 cães vacinados, após 7 dias da vacinação, o gene NP, foi detectado nas amostras desses cães, mas não foi detectado em 14 e 21 dias pós vacinação. Esse resultado mostra que o vírus vacinal pode ser excretado até 7 dias pós vacinação, utilizando a técnica de RT-PCR. Em adição, 2 cães vacinados dentro de 1 mês antes da colheita da amostra foram negativos, para VCC, pela técnica de RT-PCR. De acordo com o trabalho, esses resultados indicam que essa técnica é específica para doença causada pelo VCC. Appel (1977), sugeriu que a replicação do vírus vacinal seja restrita aos tecidos linfáticos, em cães [Blixenkrone-Moller, 1989].

Dos 60 animais que não apresentaram nenhum tipo de estória de vacinação, 40 deles foram considerados positivos pelo mesmo método e 20 animais foram considerados negativos, confirmando desta forma, que o vírus excretado era do tipo selvagem.

Dos 61 animais considerados positivos pelo método de RT-PCR, 44 deles apresentaram sintomas neurológicos, tais como: convulsão, tremores, incoordenação/mioclonia, apenas incoordenação, apenas mioclonia e paresia de membros pélvicos. Sendo que 17 animais não foram obtidas informações desses sintomas. Dos 18 animais vacinados, 14 deles apresentaram sintomas neurológicos [Anexo 3].

No estudo de Shin et al., (1995), foi examinada a presença do gene NP, em células mononucleares do sangue periférico, de 52 cães saudáveis e 32 cães suspeitos de cinomose canina, pela técnica de RT-PCR. Nenhum produto foi detectado nos cães saudáveis, indicando que a técnica de RT-PCR não mostrou nenhuma reação falso-positiva. O gene NP foi detectado em 17 das 32 amostras clínicas suspeitas. 
De acordo com dados da literatura, os cães mais jovens são mais susceptíveis ao VCC. Dos 61 animais que apresentaram positividade pelo método de Nested-PCR; 51 deles apresentaram sintomas como a conjuntivite; 31 com quadro respiratório; 26 com problema digestivo e $18 \mathrm{com}$ sintoma febril; $44 \mathrm{com}$ sinais de comprometimento do SNC, sendo que em 17 cães nã̃o foram detectados distúrbios neurológicos [Anexo 3].

Na tabela 3 podemos observar que 107 amostras, incluindo sangue, urina e saliva, respectivamente, foram consideradas positivas, usando o método de Nested-PCR, enquanto que, o método de PCR, detectou-se em apenas 06 amostras clínicas, confirmando desta forma, que a reação de Nested-PCR, mostrou-se mais sensivel e específica.

Ao examinarmos a tabela 2 (indice de positividade em amostras clínicas) encontramos 49 amostras de urina consideradas positivas, pela técnica de RTPCR, seguida de 43 de linfócitos e 18 de saliva. Entre os diferentes espécimes clínicos estudados em cães, a urina teve o maior índice de positividade de RNA viral encontrada por esse método.

No estudo de Rota et al. (1995), obtiveram maior positividade na detecção do RNA viral, também, em urina de crianças vacinadas aos 15 meses. Nesse estudo, o RNA viral foi detectado em 10 das 12 crianças estudadas em um período de 14 dias. Os autores utilizaram a técnica de imunoquimioluminescência, pelo método de "Southern blot" com o uso de "primers" internos marcados com digoxigenina, com uma alta sensibilidade e especificidade comparada ao NestedPCR.

Lima (1999), detectou o vírus do sarampo em amostras de urina de crianças após a imunização específica, embora a maior freqüência de positividade tenha sido observada na saliva. Esses dados poderiam ser explicados, devido ao longo período de estocagem dos espécimes clínicos, antes de completar o processo de extração. Na literatura, muitos trabalhos que estudam a excreção viral em espécimes clínicos foram realizados com amostras frescas, o que ocorreu em nosso estudo. No estudo de Lima (1999), os espécimes foram conservados durante periodos de até 2 anos a $-70^{\circ} \mathrm{C}$ em Trizol, não sendo possivel avaliar a 
degradação de RNA ocorrida nos espécimes clínicos congelados. De acordo com um trabalho de epidemiologia molecular de Kreis \& Schoub (1998), em amplificação viral em soros e líquidos cerebroespinhais, não foi possível a amplificação devido a degradação de RNA na maioria das amostras estocadas por longos períodos. $O$ fato de termos obtido maior êxito na deteç̧ão viral na urina dos cães com sintomatologia de cinomose, indica ser este o material clínico de excelência para o diagnóstico etiológico da infecção, seguido de sangue periférico. 
6. CONCLUSÕES 


\section{CONCLUSÕES}

Com os resultados obtidos neste estudo, concluiu-se que:

- A metodologia descrita para detecção do VCC, pela técnica da Reação em Cadeia pela Polimerase (RT-PCR), utilizando amostras clínicas de cães com sintomatologia sugestiva da doença, mostrou ser mais sensível, específica, rápida e de fácil execução, sendo possivel a implantação desta em diagnóstico de rotina, contribuindo de maneira significativa na confirmação da suspeita clínica.

- Foi demonstrado, pela técnica de RT-PCR, na deteç̧ão do RNA viral que a urina foi o espécime clínico de maior índice de positividade, seguido pelo linfócito e saliva. 


\section{REFERÊNCIAS BIBLIOGRÁFICAS}




\section{REFERÊNCIAS BIBLIOGRÁFICAS :}

ALLEMAN, A. R.; CHRISTOPHER, M. M.; STEINER, D. A. \& HOMER, B. L. Identification of Intracytoplasmic Inclusion Bodies in Mononuclear Cells from the Cerebrospinal Fluid of a Dog with Canine Distemper. Vet. Pathol., 29: 84-5, 1992.

ANDERSON, E. C. -Morbillivirus infections in wildlife in relation to their population biology and disease control in domestic animals. Vet. Microbiol., 44 (2-4): 319-32, 1995.

APPEL, M.J.G. -Pathogenesis of Canine Distemper. Am. J. Vet. Res., 30: 1167-82, 1969.

APPEL, M.J.G. -Distemper Pathogenesis in Dogs. J.A.V.M.A., 156: 1681-3, 1970.

APPEL, M.J.G. \& GILLESPIE, J. H. -Virology Monographs. New York Wien: SpringerVerlag, 1972. p. 03-96.

APPEL, M.J.G. -Virus infections of carnivores. New York: Elsevier Science Publishers, 1987. p. $133-59$.

APPEL, M. J.; PEARCE-KELLING, S.; \& SUMMERS, B. A. -Dog lymphocyte cultures facilitate the isolation and growth of virulent canine distemper virus. J. Vet. Diagn. Invest., 4 (3): 258-63, 1992.

APPEL, M. J. G. \& SUMMERS, B. A. -Pathogenicity of Morbilliviruses for terrestrial carnivores. Vet. Microbiol., 44 (2-4): 187-91, 1995.

BAKER, J. A. -Measles Vaccine for Protection of Dogs Against Canine Distemper. J.A.V.M.A., 156 (12): 1743-6, 1970. 
BARBEN, G.; STETTLER, M.; JAGGY, A.; VANDEVELDE, M. \& ZURBRIGGENIA. Detection of IgM antibodies against a recombinant nucleocapsid protein of canine distemper virus in dog sera using a dot-blot assay. Zentralble. Veterinarmed A., 46 (2): 115-21, 1999.

BELL, S. C.; CARTER, S. D. \& BENNETT, D. -Canine distemper viral antigens and antibodies in dogs with rheumatoid arthritis. Res. Vet. Sci., 50 (1): 64-8, 1991.

BELLINI, W.J.; ENGLUND, G.; RICHARDSON, C.D.; ROZENBLATT, S.; \& LAZZARINI, R.A. -Matrix Genes of Measles Virus and Canine Distemper Virus: Cloning, Nucleotide Sequences, and Deduced Amino Acid Sequences. J. Virol., 58 (2): 408-16, 1986.

BLIXENKRONE-Moller, M. -Detection of intracellular canine distemper virus antigen in mink inoculated with an attenuated or a virulent strain of canine distemper virus. Am. J. Vet. Res., 50 (9): 1616-20, 1989.

BLIXENKRONE-Moller, M. -Biological properties of phocine distemper virus and canine distemper virus. A. P. M. I. S. (suppl. 36): 01-51, 1993.

BLIXENKRONE-Moller, M.; SVANSSON, V.; HAVE, P.; ORVELL, C.; APPEL, M.; PEDERSEN, I. R.; DIETZ, H. H. \& HENRIKSEN, P. -Studies on manifestations of canine distemper virus infection in an urban dog population. Vet. Microbiol., 37 (12): 163-73, 1993.

BUSH, M.; MONTALI, R. J.; BROWNSTEIN, D.; JAMES, A. E. J. \& APPEL, M. J. G. Vaccine- Induced Canine Distemper in a Lesser Panda. J.A.V.M.A., 169 (9): 95960, 1976.

BUXTON, A. \& FRASER, G. -Animal Microbiology. Oxford: Blackwell Scientific Publications, 1977. v. 2. p. 533-48. 
CARPENTER, M. A.; APPEL, M. J.; ROELKE-PARKER, M. E.; MUNSON, L.; HOFER, H.; EAST, M. \& O'BRIEN, S. J. -Genetic characterization of canine distemper virus in Serengeti carnivores. Vet. Immunol. Immunopathol., 65 (2-4): 259-66, 1998.

CARRÉ, M. H. -Sur la Maladie des jeunes chiens. C. R. Acad. Sci. Paris, 140: 68990, 1905.

CARTWRIGHT, E.J.; GORDON, M.T.; FREEMONT, A.J.; ANDERSON, D.C. \& SHARPE, P.T. -Paramyxoviruses and Paget's Disease. J. Med. Virol., 40: 13341,1993 .

CHALMERS, W. S. K. \& BAXENDALE, W. -A comparison of canine distemper vaccine and measles vaccine for the prevention of canine distemper in young puppies. Vet. Rec., 135: 349-53, 1994.

COOK, S.D.; DOWLING, P.C. \& RUSSELL, W.C. -Multiple Sclerosis and Canine Distemper. Lancet, 1: 605-6, 1978.

CORNWELL, H. J. C.; CAMPBELL, R. S. F.; VANTSIS, J. T. \& PENNY, W. -Studies in Experimental Canine Distemper. J. Comp. Path., 75: 03-17, 1965.

CURRAN, M. D.; CLARKE, D. K. \& RIMA, B. K. -The nucleotide sequence of the gene encoding the attachment protein $\mathrm{H}$ of canine distemper virus. J. Gen. Virol., 72: 443-7, 1991.

CURRAN, M. D.; O' LOAN, D.; KENNEDY, S. \& RIMA, B. K. -Molecular characterization of phocine distemper virus: gene order and sequence of the gene encoding the attachment (H) protein. J. Gen. Virol., 73 (Pt 5): 1189-94, 1992.

DIALLO, A. -Morbillivirus group: genome organization and proteins. Vet. Microbiol., 23 (1-4): 155-63, 1990. 
DITERS, R. W. \& NIELSEN, S. W. -Toxoplasmosis, Distemper, and Herpesvirus Infection in a Skunk (Mephitis mephitis). J. Wildlife Dis., 14: 132-6, 1978.

DURCHFELD, B.; BAUMGÄRTNER, W.; HERBST, W. \& BRAHM, R. - Vaccineassociated Canine Distemper Infection in a Litter of African Hunting Dogs (Lycaon pictus). J. Vet. Med., 37: 203-12, 1990.

EK-KOMMONEN, C.; SIHVONEN, L.; PEKKANEN, K.; RIKULA, U. \& NUOTIO, L. Outbreak off canine distemper in vaccinated dogs in Finland. Vet. Rec., 141 (15): 380-3, 1997.

EVANS, M. B.; BUNN, T. O.; HILL, H. T. \& PLATT, K. B. -Comparison of in vitro replication and cytopathology caused by strains of canine distemper virus of vaccine and field origin. J. Vet. Diagn. Invest., 3 (2): 127-32, 1991.

FENNER, F.; GIBBS, E. P. J.; MURPHY, F. A.; ROTT, R.; STUDDERT, M. J. \& WHITE, D. O. -Veterinary Virology. Academic Press, 1993. v.2. p. 471-85.

GALINSKI, M. S. -Paramyxoviridae: Transcription and Replication. Advances in Virus Res., 39: 129-62, 1991.

GEERING, W. A. -Canine Distemper. Aust. Vet. J., 43 (12): 600, 1967.

GODEC, M. S.; ASHER, D. M.; SWOVELAND, P. T.; ELDADAH, Z. A.; FEINSTONE, S. M.; GOLDFARB, L. G.; GIBBS, C. J. Jr. \& GAJDUSEK, D. C. -Detection of Measles Virus Genomic Sequences in SSPE Brain Tissue by the Polymerase Chain Reaction. J. Med. Virol., 30: 237-44, 1990.

GORDON, M.T.; BELL, S. C.; MEE, A. P.; MERCER, S.; CARTER, S. D. \& SHARPE, P. T. -Prevalence of Canine Distemper Antibodies in the Pagetic Population. J. Med. Virol., 40: 313-17, 1993. 
GORET, P. -Experimental Studies upon the Canine Distemper Virus: Variations in Virulence and their Relation to the Symptomatology and Prophylaxis of the Disease. Vet. Rec., 62 (6): 67-71, 1950.

GREENE, C. E. \& BRAUND, K. G. -Diseases of the brain In: Ettinger, S. J. (eds): Textbook of Veterinary Internal Medicine. Philadelphia: W. B. Saunders Company, 1989 , p. 578-23.

GREENE, C. E. \& APPEL, M. J. -Canine Distemper. Philadelphia: W. B. Saunders, 1990. p. 226-40.

GREENE, C. E. \& APPEL, M. J. -Canine Distemper. Philadelphia: W. B. Saunders, 1998. v. 2. p. 09-22.

HAAS, L.; SUBBARAO, S. M.; HARDER, T.; LIESS, B.; \& BARRETT, T. -Detection of phocid distemper virus RNA in seal tissues using slot hybridization and the polymerase chain reaction amplification assay: genetic evidence that the virus is distinct from canine distemper virus. J. Gen. Virol., 72 (4): 825-32, 1991.

HIRAYAMA, N.; SENDA, M.; KURATA, K.; YOSHIKAWA, Y. \& YAMANOUCHI, K. Requirement of Methionine for the Replication of Canine Distemper Virus in Vero Cells. J. Gen. Virol., 66: 149-57, 1985.

HIRAYAMA, N.; SENDA, M.; YAMAMOTO, H.; KURATA, K.; YOSHIKAWA, Y. \& YAMANOUCHI, K. -Comparison of biological and molecular properties among canine distemper virus strains. Nippon Juigaku Zasshi, 48 (2): 259-65, 1986.

IWATSUKI, K.; OKITA, M.; OCHIKUBO, F.; GEMMA, T.; SHIN, Y. S.; MIYASHITA, N.; MIKAMI, T. \& KAI, C. -Immunohistochemical analysis of the lymphoid organs of dogs naturally infected with canine distemper virus. J. Comp. Pathol., 113 (2): 18590, 1995. 
KAI, C.; OCHIKUBO, F.; OKITA, M.; IINUMA, T.; MIKAMI, T.; KOBUNE, F. \& YAMANOUCHI, K. -Use of B95a Cells for Isolation of Canine Distemper Virus from Clinical Cases. J. Vet. Med. Sci., 55 (6): 1067-70, 1993.

KREIS, S. \& SCHOUB, B. D. -Partial amplification of the measles virus nucleocapsid gene from stored sera and cerebrospinal fluids formolecular epidemiological studies. Med. Virol., 56: 174-77, 1998.

LAIDLAW, P. P. \& DUNKIN, G. W. -Studies in Dog Distemper. J. Comp. Pathol. and Ther., 19: 209-27, 1928.

LAMB, R. A. \& KOLAKOFSKY, D. Paramyxoviridae: -The Viruses and Their Replication In: Fields, B. N., Knipe, D. M., Howley, P. M. (eds): Fundamental Virology. Philadelphia: Lippincott-Raven, 1996, p. 577-604.

LIMA, L. R. A. V. -Avaliação da Resposta Imune da excreção viral em crianças vacinadas contra o sarampo. São Paulo, 1999 (Tese de Doutorado-Instituto de Ciências Biomédicas da Universidade de São Paulo).

LITTLE, S. E.; DAVIDSON, W. R.; HOWERTH, E. W.; RAKICH, P. M. \& NETTLES, V. F. -Diseases Diagnosed in Red Foxes from the Southeastern United States. J. Wildlife Dis., 34 (3): 620-24, 1998.

LÖFFLER, S.; LOTTSPEICH, F.; LANZA, F.; AZORSA, D. O.; MEULEN, V. T. \& SCHAULIES, J. S. -CD9, a Tetraspan Transmembrane Protein, Renders Cells Susceptible to Canine Distemper Virus. J. Virol., 71 (1): 42-9, 1997.

LOVE, D. N. -Review of canine viral disease. Aust. Vet. J., 48 (10): 567-70, 1972.

LYONS, C.; WELSH, M. J.; THORSEN, J.; RONALD, K. \& RIMA, B. K. -Canine distemper virus isolated from a captive seal. Vet. Rec., 132: 487-8, 1993. 
MAEDA, H.; OZAKI, K.; TAKAGI, Y.; SAWASHIMA, K. \& NARAMA, I. -Distemper Skin Lesions in a Dog. J. Vet. Med., 41: 247-50, 1994.

MAINKA, S. A.; XIANMENG, Q.; TINGMEI, H. \& APPEL, M.J.G. -Serologic Survey of Giant Pandas (Ailuropoda melanoleuca), and Domestic Dogs and Cats in the Wolong Reserve, China. J. Wildlife Dis., 30 (1): 86-9, 1994.

MARSILIO, F.; TISCAR, P. G.; GENTILE, L.; ROTH, H. U.; BOSCAGLI, G.; TEMPESTA, M. \& GATTI, A. -Serologic Survey for Selected Viral Pathogens in Brown Bears from Italy. J. Wildlife Dis., 33 (2): 304-7, 1997.

MEE, A. P. \& SHARDE, P. T. -Dogs, distemper and Paget's disease. Bioessays, 15 (12): 783-9, 1993.

MEE, A. P.; DIXON, J. A.; HOYLAND, J. A.; DAVIES, M.; SELBY, P. L.; MAWER, E. B. -Detection of canine distemper virus in $100 \%$ of Paget's disease samples by in situreverse transcriptase-polymerase chain reaction. Bone, 23 (2): 171-5, 1998.

MITCHELL, W. J.; RUSSELL, S. E. H.; CLARK, D. K.; RIMA, B. K. \& APPEL, M. J. Identification of negative strand and positive strand RNA of canine distemper virus in animal tissues using single stranded RNA probes. J. Virol. Methods, 18: 121-31, 1987.

MOLLER, M. B.; SVANSSON, V.; HAVE, P.; ORVELL, C.; APPEL, M.; PEDERSEN, I. R.; DIETZ, H. H. \& HENRIKSEN, P. -Studies on manifestations of canine distemper virus infection in an urban dog population. Vet. Microbiol., 37: 163-73, 1993.

MORI, T.; SHIN, Y. S.; OKITA, M.; HIRAYAMA, N.; MIYASHITA, N.; GEMMA, T.; KAI, C. \& MIKAMI, T. -The biological characterization of field isolates of canine distemper virus from Japan. J. Gen. Virol., 75: 2403-8, 1994.

MURPHY, F. A. -Virus Taxonomy In: Fields, B. N., Knipe, D. M., Howley, P. M. (eds): Virology. Philadelphia: Lippincott-Raven, 1996, p. 15-57. 
NORRBY, E.; UTTER, G.; ÖRVELL, C. \& APPEL, M. J. G. -Protection against Canine Distemper Virus in Dogs after Immunization with Isolated Fusion Protein. J. Virol., 58 (2): 536-41, 1986.

OGLESBEE, M.; JACKWOOD, D.; PERRINE, K.; AXTHELM, M.; KRAKOWKA, S. \& RICE, J. -In vitro detection of canine distemper virus nucleic acid with a virusspecific cDNA probe by dot-blot and in situ hybridization. J. Virol. Methods, 14: 195-211, 1986.

OGLESBEE, M.; TATALICK, L.; RICE, J. \& KRAKOWKA, S. -Isolation and Characterization of Canine Distemper Virus Nucleocapsid Variants. J. Gen. Virol., 70 (Pt 9): 2409-19, 1989.

OHASHI, K.; IWATSUKI, K.; NAKAMURA, K.; MIKAMI, T. \& KAI, C. -Molecular identification of a recent type of canine distemper virus in Japan by restriction fragment length polymorphism. J. Vet. Med. Sci., 60 (11): 1209-12, 1998.

PALMER, D. G.; HUXTABLE, C. R. \& THOMAS, J. B. -Immunohistochemical demonstration of canine distemper virus antigen as an aid in the diagnosis of canine distemper encephalomyelitis. Res. Vet. Sci., 49 (2): 177-81, 1990.

PEARCE-KELLING, S.; MITCHELL, W. J.; SUMMERS, B. A. \& APPEL, M. J. -Growth of canine distemper virus in cultured astrocytes: relationship to in vivo persistence and disease. Microb. Pathog., 8 (1): 71-82, 1990.

PEÑA, M. L.; QUIROGA, M. I.; VÁZQUEZ, S. \& NIETO, J. M. -Detection of Canine Distemper Viral Antigen in Foxes (Vulpes vulpes) in Northwestern Spain. J. Wildlife Dis., 30 (1): 95-8, 1994.

RECULARD, P. \& GUILLON, J. C. -lsolement d'une souche de virus de la maladie de Carré à propriétés biologiques particulières. Bull. Acad. Vet. Fr., 40 (10): 507-11, 1967. 
RIMA, B. K.; BACZKO, K.; CLARKE, D. K.; CURRAN, M. D.; MARTIN, S. J.; BILLETER, M. A. \& MEULEN, V. T. -Characterization of Clones for the Sixth (L) Gene and a Transcriptional Map for Morbilliviruses. J. Gen. Virol., 67: 1971-8, 1986.

RIMA, B. K.; DUFFY, N.; MITCHELL, W, J.; SUMMERS, B. A. \& APPEL, M. J.Correlation between humoral immune responses and presence of virus in the CNS in dogs experimentally infected with canine distemper virus. Arch. Virol., 121 (1-4): 01-8, 1991.

RIMA, B.; ALEXANDER, D. J.; BILLETER, M. A.; COLLINS, P. L.; KINGSBURY, D. W.; LIPKIND, M. A.; NAGAI, Y.; ÖRVELL, C.; PRINGLE, C. R. \& ter MEULEN, V. Paramyxoviridae. Virus taxonomy. Classification and nomenclature of viruses. Sixth report of the International Committee on Taxonomy of Viruses. Arch. Virol., (suppl. 10): S268-74, 1995.

ROTA, P.A.; KHAN, A.S.; DURIGON, E.; YURAN, T.; VILLAMARZO, Y.S.; \& BELLINI, W.J. -Detection of Measles Virus RNA in Urine Specimens from Vaccine Recipients. J. Clin. Microbiol., 33 (9): 2485-8,1995.

ROZENBLATT, S.; EIZENBERG, O.; BEN-LEVY, R.; LAVIE, V.; \& BELLINI, W. J. Sequence Homology Within the Morbilliviruses. J. Virol., 53 (2): 684-90,1985.

ROZENBLATT, S.; EIZENBERG, O.; ENGLUND, G. \& BELLINI, W. J. -Cloning and Characterization of DNA Complementary to the Canine Distemper Virus in RNA Encoding Matrix, Phosphoprotein, and Nucleocapsid Protein. J. Virol., 53 (2): 6914, 1985.

SAIKI, R.K.; GELFAND, D.H.; STOFFEL, S.; SCHARF, S.J.; HIGUCHI, R.; HORN, G.T.; MULLIS, K.B. \& ERLICH, H.A. -Primer-Directed Enzymatic Amplification of DNA with a Thermostable DNA Polymerase. Science, 239: 487-91,1988. 
SCHLINGMAN, A. S. -Studies on Canine Distemper: A Comparison of Natural and Experimental Virus Infections. J. Am. Vet. Med. Assoc., 82: 164-88, 1933.

SCHULTZ, R. D. \& ADAMS, L. S. -Immunologic Methods for the detection of humoral and cellular immunity. Vet. Clin. North. Am., 8 (4): 721-53, 1978.

SHESHBERADARAN, H.; NORRBY, E.; McCULLOUGH, K. C.; CARPENTER, W. C. \& ORVELL, C. - The antigenic relationship between measles, canine distemper and rinderpest viruses studied with monoclonal antibodies. J. Gen. Virol., 67 (7): 138192, 1986.

SHIMIZU, H.; SHIMIZU, C. \& BURNS, J.C. -Detection of novel RNA viruses: morbilliviruses as a model system. Molecular and Cellular Probes, 8 (3): 20914,1994 .

SHIN, Y. S.; MORI, T.; OKITA, M.; GEMMA, T.; KAI, C. \& MIKAMI, T. -Detection of Canine Distemper Virus Nucleocapsid Protein Gene in Canine Peripheral Blood Mononuclear Cells by RT-PCR. J. Vet. Med. Sci., 57 (3): 439-45, 1995.

SIDHU, M. S.; HUSAR, W.; COOK, S. D.; DOWLING, P. C. \& UDEM, S. A. -Canine Distemper Terminal and Intergenic Non-protein Coding Nucleotide Sequences: Completion of the Entire CDV Genome Sequence. Virology, 193 (1): 66-72, 1993.

STETTLER, M. \& ZURBRIGGEN, A. - Nucleotide and deduced amino acid sequences of the nucleocapsid protein of the virulent A75/17-CDV strain of canine distemper virus. Vet. Microbiol., 44 (2-4): 211-7, 1995.

SUMMERS, B.A. \& APPEL, M.J.G. -Syncytia Formation: An Aid in the Diagnosis of Canine Distemper Encephalomyelitis. J. Comp. Path., 95: 425-35, 1985.

SVANSSON, V.; BLIXENKRONE-Moller, M.; SKIRNISSON, K.; HAVE, P.; HEJE, N. I.; NIELSEN, J. \& LUND, E. -Infection studies with canine distemper virus in harbour seals. Arch. Virol., 131: 349-59, 1993. 
SWANGO, L. J. -Canine Viral Diseases In: Ettinger, S. J. (eds): Textbook of Veterinary Internal Medicine. Philadelphia: W. B. Saunders Company, 1989, p. 298-311.

THOMAS, W. B.; SORJONEN, D. C. \& STEISS, J. E. -A Retrospective Evaluation of 38 cases of Canine Distemper Encephalomyelitis. J. American Animal Hospital Assoc., 29: 129-33, 1993.

THOMAS, W. B. -Inflammatory Diseases of the Central Nervous System in Dogs. Clin. Techniques in Small Animal Practice, 13 (3): 167-78, 1998.

TIPOLD, A. -Diagnosis of Inflammatory and infectious Diseases of the Central Nervous System in Dogs: A Retrospective Study. J. Vet. Internal Medicine, 9 (5): 304-14, 1995.

VAINIONPÄÄ, R.; MARUSYK, R. \& SALMI, A. -The Paramyxoviridae: Aspects of Molecular Structure, Pathogenesis, and Immunity. Advances in Virus Res., 37: 211-42, 1989.

van MOLL, P.; ALLDINGER, S.; BAUMGARTNER, W. \& ADAMI, M. -Distemper in wild carnivores: an epidemiological, histological and immunocytochemical study. Vet. Microbiol., 44 (2-4): 193-9, 1995.

VANDEVELDE, M. \& ZURBRIGGEN, A. -The neurobiology of canine distemper virus infection. Vet. Microbiol., 44 (2-4): 271-80, 1995.

von MESSLING, V.; HARDER, T. C.; MOENNIG, V.; RAUTENBERG, P.; NOLTE, I. \& HAAS, L. -Rapid and sensitive detection of immunoglobulin $M$ (IgM) and $\lg G$ antibodies against canine distemper virus by a new recombinant nucleocapsid protein-based enzyme-linked immunosorbent assay. J. Clin. Microbiol., 37 (4): 1049-56, 1999. 
VISSER, I. K. G.; KUMAREV, V. P.; ÖRVELL, C.; de VRIES, P.; BROEDERS, H. W. J.; van de BILDT, M. W. G.; GROEN, J.; TEPPEMA, J. S.; BURGER, M. C.; UYTDEHAAG, F. G. C. M. \& OSTERHAUS, A. D. M. E. -Comparison of two morbilliviruses isolated from seals during outbreaks of distemper in North West Europe and Siberia. Arch. Virol., 111: 149-64, 1990.

WANER, T.; NAVEH, A.; BEN MEIR, N. S.; BABICHEV, Z. \& CARMICHAEL, L. E. Assessment of Immunization Response to Canine Distemper Virus Vaccination in Puppies Using a Clinic-based Enzyme-linked Immunosorbant Assay. Vet. J., 155 (2): 171-5, 1998.

WRIGHT, N. G.; CORNWELL, J. C.; THOMPSON, H. \& LAUDER, I. M. -Canine distemper: current concepts in laboratory and clinical diagnosis. Vet. Rec., 94: 8692, 1974.

YOSHIDA, E.; IWATSUKI, K.; MIYASHITA, N.; GEMMA, T.; KAI, C. \& MIKAMI, T. Molecular analysis of the nucleocapsid protein of recent isolates of canine distemper virus in Japan. Vet. Microbiol., 59 (2-3): 237-44, 1998.

YOSHIKAWA, Y.; OCHIKUBO, F.; MATSUBARA, Y.; TSURUOKA, H.; ISHII, M.; SHIROTA, K.; NOMURA, Y.; SUGIYAMA, M. \& YAMANOUCHI, K. -Natural Infections with Canine Distemper Virus in a Japanese Monkey (Macaca fuscata). Vet. Microbiol., 20: 193-205, 1989.

ZURBRIGGEN, A.; MÜLLER, C.; VANDEVELDE, M. -In situ hybridization of virulent canine distemper virus in brain tissue, using digoxigenin-labeled probes. Am. J. Vet. Res., 54 (9): 1457-61, 1993.

ZURBRIGGEN, A.; SCHMID, I.; GRABER, H. U. \& VANDEVELDE, M. Oligodendroglial pathology in canine distemper. Acta neuropathol. (Berl), 95 (1): 71-7, 1998. 


\section{Abstract}

Canine distemper virus (CDV) is a highly contagious viral pathogen which may cause lethal systemic in dogs and other carnivores throughout the world. Affected dogs show gastrointestinal and respiratory clinical signs, and frequently develop clinical signs in the central nervous system (CNS). Clinical manifestations of the disease include depression, progressive loss of weight, dehydration, hyperkeratosis of the foot pads and nose, nervous symptoms and muscular spasms or posterior paralysis which may persist for long periods. Infected dogs with clinical symptoms for CDV, were by detection of viral RNA by Polymerase Chain Reaction (PCR) and Nested PCR.

In this study, we determined by the RT-PCR the presence of nucleoprotein (NP) gene in peripheral blood mononuclear cells, urine and saliva from dogs infected with CDV. The goals of this study was to detect CDV genome by RT-PCR in different clinical samples. In this study, identification of NP mRNA was successfully achieved by using the RT-PCR method with two sets of NP gene specific primers. The RT-PCR technique described in this study, may provide a useful assay system to determine whether the dogs suspected of CDV infection have detectable levels of CDV genes. The results demonstrate that RT-PCR technique is rapid, sensitivity and specificity for virus diagnosis. 
ANEXOS 
Anexo 1- Número de espécimes clínicas (sangue, urina e saliva), coletados de 100 animais provenientes do HOVET, com sintomatologia sugestiva de cinomose canina.

Data de entrada № Prontuário № Laboratório Material clínico

\begin{tabular}{|c|c|c|c|}
\hline 25/08/97 & 78333 & 01 & sangue, urina e saliva \\
\hline 25/08/97 & 78720 & 02 & sangue e saliva \\
\hline 25/08/97 & 78802 & 03 & sangue e saliva \\
\hline $27 / 08 / 97$ & 77803 & 04 & sangue, urina e saliva \\
\hline 28/08/97 & 78842 & 05 & sangue, urina e saliva \\
\hline 28/08/97 & 78976 & 06 & sangue, urina e saliva \\
\hline 29/08/97 & 79020 & 07 & sangue, urina e saliva \\
\hline 03/09/97 & 79158 & 08 & sangue, urina e saliva \\
\hline 03/09/97 & 79161 & 09 & sangue, urina e saliva \\
\hline 03/09/97 & 79164 & 10 & sangue, urina e saliva \\
\hline 04/09/97 & 79122 & 11 & sangue e saliva \\
\hline 04/09/97 & 79202 & 12 & sangue, urina e saliva \\
\hline 04/09/97 & 79219 & 13 & sangue, urina e saliva \\
\hline 04/09/97 & 77628 & 14 & sangue, urina e saliva \\
\hline 05/09/97 & 79187 & 15 & sangue, urina e saliva \\
\hline 05/09/97 & 79273 & 16 & sangue e saliva \\
\hline 09/09/97 & 79196 & 17 & sangue, urina e saliva \\
\hline 09/09/97 & 79269 & 18 & sangue, urina e saliva \\
\hline 12/09/97 & 79490 & 19 & sangue, urina e saliva \\
\hline $17 / 09 / 97$ & 79634 & 20 & sangue e saliva \\
\hline $22 / 09 / 97$ & 79556 & 21 & sangue, urina e saliva \\
\hline $22 / 09 / 97$ & 79626 & 22 & sangue, urina e saliva \\
\hline $22 / 09 / 97$ & 79759 & 23 & sangue e saliva \\
\hline $22 / 09 / 97$ & 79775 & 24 & sangue e saliva \\
\hline $02 / 10 / 97$ & 80112 & 25 & sangue, urina e saliva \\
\hline
\end{tabular}




\begin{tabular}{|c|c|c|c|}
\hline $03 / 10 / 97$ & 80180 & 26 & sangue, urina e saliva \\
\hline $08 / 10 / 97$ & 80187 & 27 & sangue, urina e saliva \\
\hline $08 / 10 / 97$ & 80301 & 28 & sangue, urina e saliva \\
\hline $10 / 10 / 97$ & 80341 & 29 & sangue, urina e saliva \\
\hline $10 / 10 / 97$ & 80379 & 30 & sangue, urina e saliva \\
\hline $15 / 10 / 97$ & 80410 & 31 & sangue, urina e saliva \\
\hline $15 / 10 / 97$ & 80448 & 32 & sangue e saliva \\
\hline $15 / 10 / 97$ & 80482 & 33 & sangue, urina e saliva \\
\hline $15 / 10 / 97$ & 80501 & 34 & sangue, urina e saliva \\
\hline $15 / 10 / 97$ & 80529 & 35 & sangue, urina e saliva \\
\hline $16 / 10 / 97$ & 78144 & 36 & sangue e saliva \\
\hline $16 / 10 / 97$ & 80544 & 37 & sangue, urina e saliva \\
\hline $16 / 10 / 97$ & 80552 & 38 & sangue, urina e saliva \\
\hline $17 / 10 / 97$ & 80598 & 39 & sangue, urina e saliva \\
\hline $20 / 10 / 97$ & 80652 & 40 & sangue, urina e saliva \\
\hline $21 / 10 / 97$ & 80684 & 41 & sangue, urina e saliva \\
\hline $21 / 10 / 97$ & 80712 & 42 & sangue, urina e saliva \\
\hline $22 / 10 / 97$ & 80724 & 43 & sangue, urina e saliva \\
\hline $23 / 10 / 97$ & 80577 & 44 & sangue, urina e saliva \\
\hline $27 / 10 / 97$ & 80862 & 45 & sangue, urina e saliva \\
\hline $28 / 10 / 97$ & 80918 & 46 & sangue e saliva \\
\hline $28 / 10 / 97$ & 80932 & 47 & sangue, urina e saliva \\
\hline $28 / 10 / 97$ & 80955 & 48 & sangue, urina e saliva \\
\hline $29 / 10 / 97$ & 80964 & 49 & sangue, urina e saliva \\
\hline $30 / 10 / 97$ & 81020 & 50 & sangue, urina e saliva \\
\hline $31 / 10 / 97$ & 80526 & 51 & sangue, urina e saliva \\
\hline $31 / 10 / 97$ & 81039 & 52 & sangue, urina e saliva \\
\hline $31 / 10 / 97$ & 81057 & 53 & sangue, urina e saliva \\
\hline $31 / 10 / 97$ & 81083 & 54 & sangue e saliva \\
\hline $03 / 11 / 97$ & 81124 & 55 & sangue, urina e saliva \\
\hline
\end{tabular}




\begin{tabular}{|c|c|c|c|}
\hline $04 / 11 / 97$ & 81170 & 56 & sangue, urina e saliva \\
\hline $04 / 11 / 97$ & 81174 & 57 & sangue, urina e saliva \\
\hline $04 / 11 / 97$ & 81193 & 58 & sangue e saliva \\
\hline $05 / 11 / 97$ & 80968 & 59 & sangue e saliva \\
\hline $05 / 11 / 97$ & 81202 & 60 & sangue, urina e saliva \\
\hline $06 / 11 / 97$ & 65509 & 61 & sangue e saliva \\
\hline $06 / 11 / 97$ & 71690 & 62 & sangue, urina e saliva \\
\hline $06 / 11 / 97$ & 81243 & 63 & sangue, urina e saliva \\
\hline $06 / 11 / 97$ & 81258 & 64 & sangue, urina e saliva \\
\hline $07 / 11 / 97$ & 81293 & 65 & sangue e saliva \\
\hline $11 / 11 / 97$ & 81398 & 66 & sangue, urina e saliva \\
\hline $11 / 11 / 97$ & 81445 & 67 & sangue, urina e saliva \\
\hline $11 / 11 / 97$ & 81451 & 68 & sangue e saliva \\
\hline $12 / 11 / 97$ & 74843 & 69 & sangue e saliva \\
\hline $13 / 11 / 97$ & 81487 & 70 & sangue, urina e saliva \\
\hline $13 / 11 / 97$ & 81491 & 71 & sangue, urina e saliva \\
\hline $13 / 11 / 97$ & 81530 & 72 & sangue, urina e saliva \\
\hline $12 / 03 / 98$ & 84748 & 73 & sangue, urina e saliva \\
\hline $12 / 03 / 98$ & 84784 & 74 & sangue, urina e saliva \\
\hline $13 / 03 / 98$ & 84829 & 75 & sangue, urina e saliva \\
\hline $13 / 03 / 98$ & 84859 & 76 & sangue, urina e saliva \\
\hline $16 / 03 / 98$ & 84906 & 77 & sangue, urina e saliva \\
\hline $18 / 03 / 98$ & 85003 & 78 & sangue, urina e saliva \\
\hline $20 / 03 / 98$ & 85082 & 79 & sangue, urina e saliva \\
\hline $16 / 04 / 98$ & 85832 & 80 & sangue, urina e saliva \\
\hline $24 / 04 / 98$ & 70484 & 81 & sangue, urina e saliva \\
\hline $24 / 04 / 98$ & 86038 & 82 & sangue, urina e saliva \\
\hline 05/05/98 & 86232 & 83 & sangue, urina e saliva \\
\hline 08/05/98 & 86347 & 84 & sangue \\
\hline 08/05/98 & 86359 & 85 & sangue \\
\hline
\end{tabular}




\begin{tabular}{|c|c|c|c|}
\hline $11 / 05 / 98$ & 86396 & 86 & sangue, urina e saliva \\
\hline $13 / 05 / 98$ & 86461 & 87 & sangue, urina e saliva \\
\hline $13 / 05 / 98$ & 86505 & 88 & sangue, urina e saliva \\
\hline $01 / 06 / 98$ & 87083 & 89 & sangue, urina e saliva \\
\hline $03 / 06 / 98$ & 87048 & 90 & sangue, urina e saliva \\
\hline $05 / 06 / 98$ & 87220 & 91 & sangue, urina e saliva \\
\hline $15 / 06 / 98$ & 87220 & 92 & sangue, urina e saliva \\
\hline $02 / 10 / 98$ & 90945 & 93 & sangue, urina e saliva \\
\hline $05 / 10 / 98$ & 82558 & 94 & sangue, urina e saliva \\
\hline $05 / 10 / 98$ & 90981 & 95 & sangue, urina e saliva \\
\hline $07 / 10 / 98$ & 91056 & 96 & sangue, urina e saliva \\
\hline $07 / 10 / 98$ & 91094 & 97 & sangue, urina e saliva \\
\hline $20 / 10 / 98$ & 91490 & 98 & sangue e saliva \\
\hline $23 / 10 / 98$ & 91628 & 99 & sangue, urina e saliva \\
\hline $28 / 10 / 98$ & 91776 & 100 & sangue, urina e saliva \\
\hline
\end{tabular}


Anexo 2- Resultado de PCR/Nested para diagnóstico da cinomose canina com primers específicos, em espécimes clinicas de sangue, urina e saliva, provenientes de 100 animais, com sintomatologia sugestiva de cinomose canina atendidos no HOVET.

\section{N Noprontuário $^{\circ}$ ICB-USP Amostras}

\begin{tabular}{|c|c|c|c|c|}
\hline & & linfócito & Urina & saliva \\
\hline 78333 & 01 & negativo & positivo & negativo \\
\hline 78720 & 02 & positivo & $\mathrm{NC}$ & negativo \\
\hline 78802 & 03 & positivo & NC & negativo \\
\hline 77803 & 04 & positivo & negativo & positivo \\
\hline 78842 & 05 & positivo & negativo & negativo \\
\hline 78976 & 06 & negativo & negativo & negativo \\
\hline 79020 & 07 & negativo & negativo & negativo \\
\hline 79158 & 08 & positivo & negativo & positivo \\
\hline 79161 & 09 & negativo & positivo & positivo \\
\hline 79164 & 10 & negativo & negativo & negativo \\
\hline 79122 & 11 & negativo & NC & negativo \\
\hline 79202 & 12 & NR & positivo & positivo \\
\hline 79219 & 13 & NR & positivo & positivo \\
\hline 77628 & 14 & NR & positivo & negativo \\
\hline 79187 & 15 & NR & positivo & negativo \\
\hline 79273 & 16 & NR & NC & negativo \\
\hline 79196 & 17 & negativo & negativo & negativo \\
\hline 79269 & 18 & negativo & negativo & negativo \\
\hline 79490 & 19 & negativo & positivo & positivo \\
\hline 79634 & 20 & negativo & NC & negativo \\
\hline 79556 & 21 & negativo & positivo & negativo \\
\hline 79626 & 22 & negativo & positivo & positivo \\
\hline 79759 & 23 & negativo & $\mathrm{NC}$ & negativo \\
\hline
\end{tabular}




\begin{tabular}{|c|c|c|c|c|}
\hline 79775 & 24 & negativo & NC & negativo \\
\hline 80112 & 25 & positivo & positivo & positivo \\
\hline 80180 & 26 & positivo & positivo & positivo \\
\hline 80187 & 27 & positivo & positivo & negativo \\
\hline 80301 & 28 & positivo & positivo & positivo \\
\hline 80341 & 29 & positivo & positivo & negativo \\
\hline 80379 & 30 & positivo & positivo & negativo \\
\hline 80410 & 31 & positivo & positivo & positivo \\
\hline 80448 & 32 & positivo & $\mathrm{NC}$ & negativo \\
\hline 80482 & 33 & positivo & positivo & negativo \\
\hline 80501 & 34 & negativo & positivo & negativo \\
\hline 80529 & 35 & negativo & negativo & negativo \\
\hline 78144 & 36 & positivo & NC & negativo \\
\hline 80544 & 37 & negativo & positivo & negativo \\
\hline 80552 & 38 & positivo & positivo & negativo \\
\hline 80598 & 39 & negativo & positivo & negativo \\
\hline 80652 & 40 & positivo & positivo & negativo \\
\hline 80684 & 41 & positivo & positivo & negativo \\
\hline 80712 & 42 & negativo & positivo & negativo \\
\hline 80724 & 43 & negativo & negativo & negativo \\
\hline 80577 & 44 & negativo & positivo & positivo \\
\hline 80862 & 45 & positivo & positivo & positivo \\
\hline 80918 & 46 & positivo & NC & positivo \\
\hline 80932 & 47 & positivo & positivo & negativo \\
\hline 80955 & 48 & positivo & positivo & negativo \\
\hline 80964 & 49 & positivo & positivo & negativo \\
\hline 81020 & 50 & positivo & positivo & positivo \\
\hline 80526 & 51 & positivo & positivo & negativo \\
\hline 81039 & 52 & negativo & negativo & negativo \\
\hline 81057 & 53 & positivo & positivo & negativo \\
\hline
\end{tabular}




\begin{tabular}{|c|c|c|c|c|}
\hline 81083 & 54 & positivo & NC & positivo \\
\hline 81124 & 55 & positivo & positivo & negativo \\
\hline 81170 & 56 & positivo & positivo & negativo \\
\hline 81174 & 57 & negativo & positivo & negativo \\
\hline 81193 & 58 & positivo & NC & negativo \\
\hline 80968 & 59 & negativo & NC & negativo \\
\hline 81202 & 60 & negativo & positivo & negativo \\
\hline 65509 & 61 & negativo & NC & negativo \\
\hline 71690 & 62 & positivo & positivo & negativo \\
\hline 81243 & 63 & positivo & positivo & positivo \\
\hline 81258 & 64 & positivo & positivo & negativo \\
\hline 81293 & 65 & negativo & NC & negativo \\
\hline 81398 & 66 & positivo & negativo & negativo \\
\hline 81445 & 67 & positivo & positivo & negativo \\
\hline 81451 & 68 & negativo & negativo & negativo \\
\hline 74843 & 69 & negativo & NC & negativo \\
\hline 81487 & 70 & negativo & positivo & negativo \\
\hline 81491 & 71 & positivo & positivo & negativo \\
\hline 81530 & 72 & positivo & positivo & negativo \\
\hline 84748 & 73 & positivo & negativo & negativo \\
\hline 84784 & 74 & negativo & negativo & negativo \\
\hline 84829 & 75 & negativo & negativo & negativo \\
\hline 84859 & 76 & negativo & negativo & negativo \\
\hline 84906 & 77 & negativo & negativo & negativo \\
\hline 85003 & 78 & negativo & negativo & negativo \\
\hline 85082 & 79 & positivo & positivo & negativo \\
\hline 85832 & 80 & positivo & positivo & negativo \\
\hline 70484 & 81 & positivo & positivo & positivo \\
\hline 86038 & 82 & negativo & negativo & negativo \\
\hline 86232 & 83 & negativo & negativo & negativo \\
\hline
\end{tabular}




\begin{tabular}{|l|l|l|l|l|}
\hline 86347 & 84 & negativo & NC & NC \\
\hline 86359 & 85 & negativo & NC & NC \\
\hline 86396 & 86 & positivo & positivo & negativo \\
\hline 86461 & 87 & negativo & positivo & negativo \\
\hline 86505 & 88 & negativo & negativo & negativo \\
\hline 87083 & 89 & negativo & negativo & negativo \\
\hline 87048 & 90 & positivo & positivo & negativo \\
\hline 87220 & 91 & negativo & negativo & negativo \\
\hline 87423 & 92 & negativo & NC & negativo \\
\hline 90945 & 93 & negativo & negativo & negativo \\
\hline 82558 & 94 & negativo & negativo & negativo \\
\hline 90981 & 95 & negativo & negativo & negativo \\
\hline 91056 & 96 & negativo & negativo & negativo \\
\hline 91094 & 97 & negativo & negativo & negativo \\
\hline 91490 & 98 & negativo & NC & negativo \\
\hline 91628 & 99 & negativo & negativo & negativo \\
\hline 91776 & 100 & negativo & negativo & negativo \\
\hline
\end{tabular}
NR - não realizado
NC - não coletado 


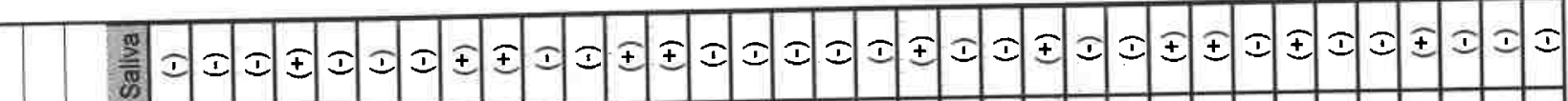

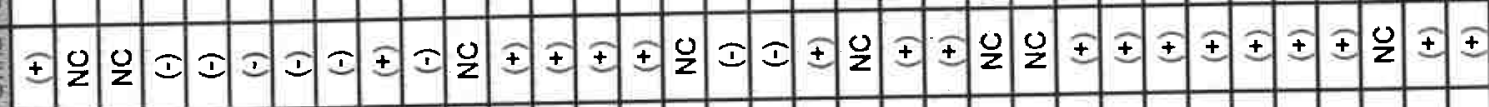

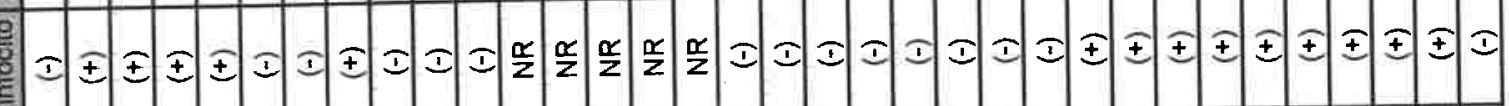

i

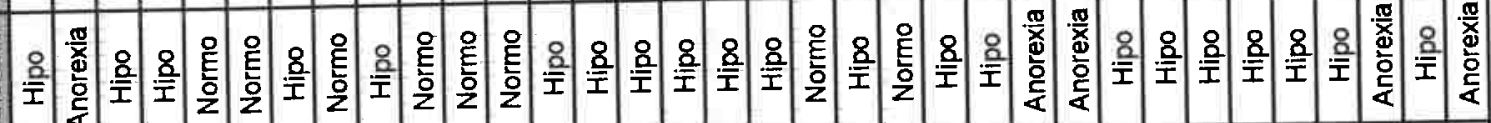

Ð

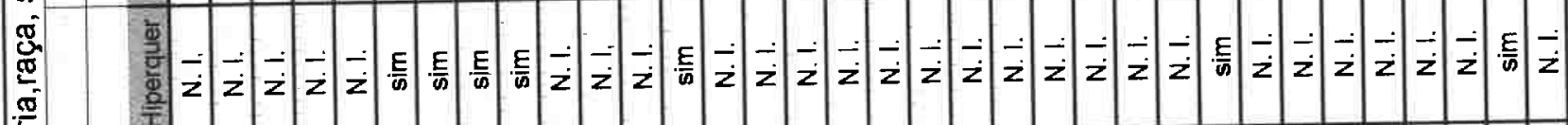

要

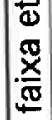

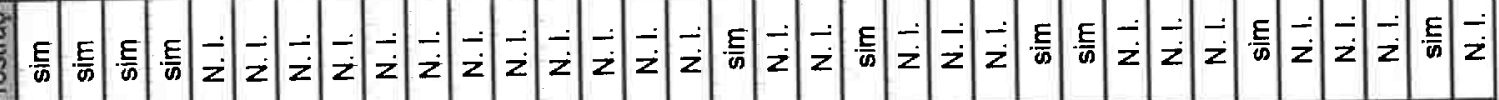

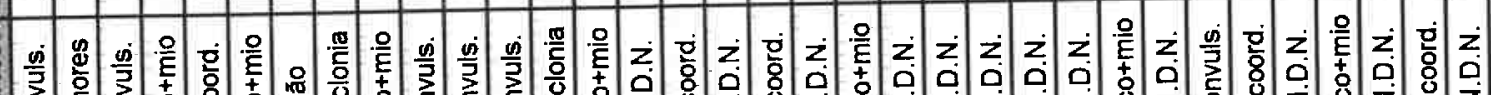

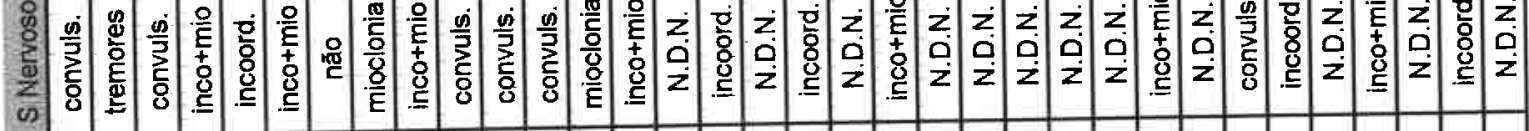

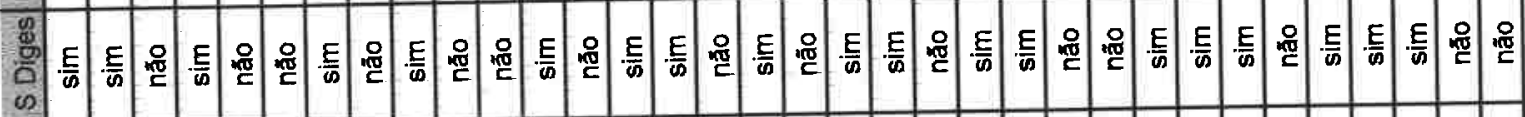
(5)

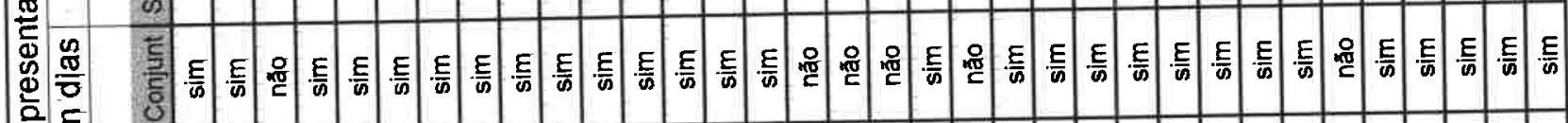

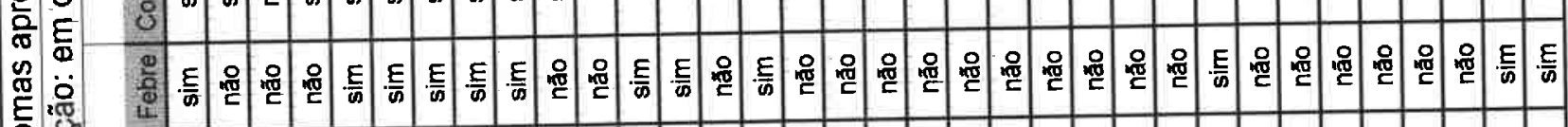

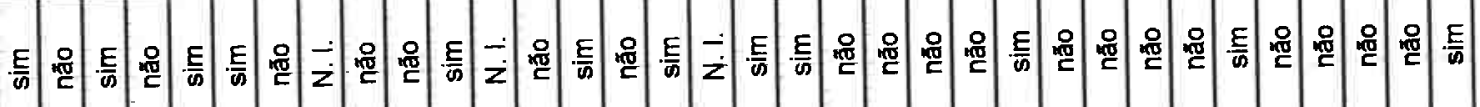

힝

$\frac{n}{\sigma}$

\%

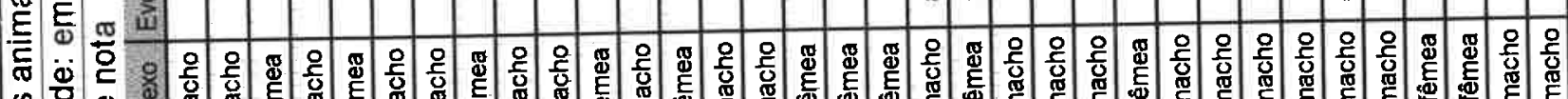

일. :

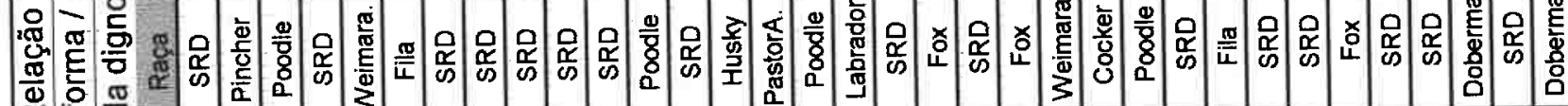
幽

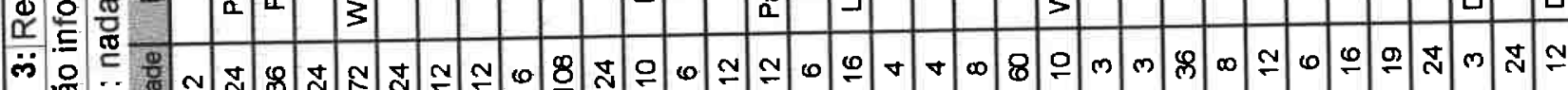




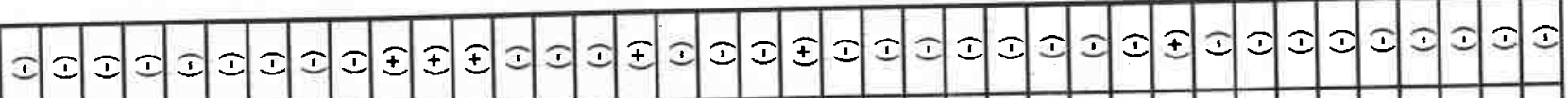

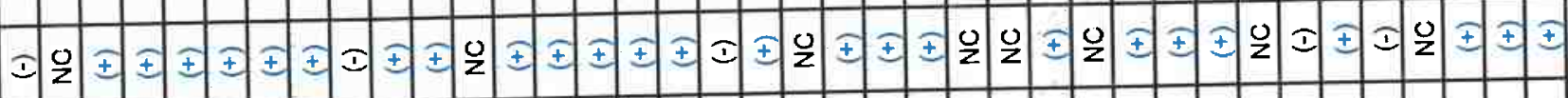

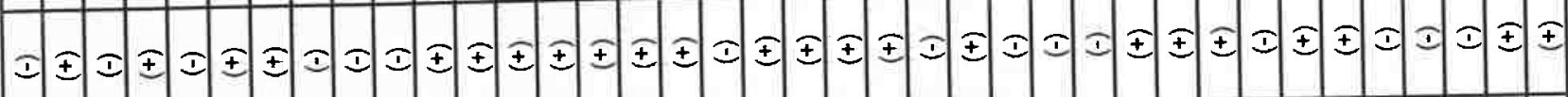

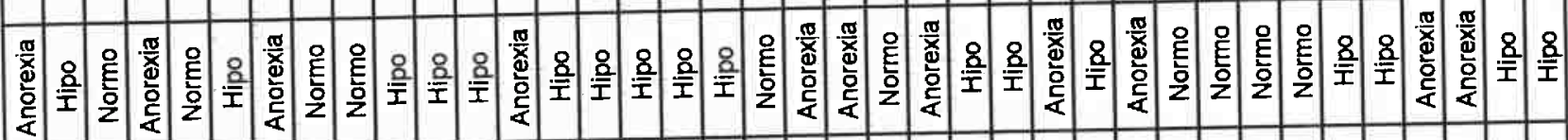
运-

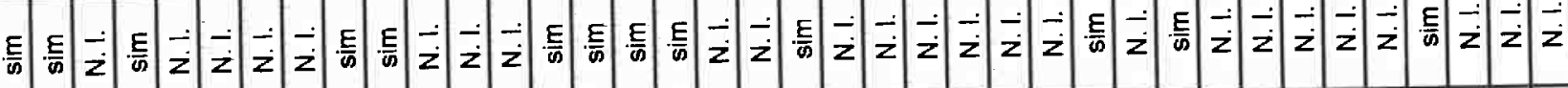

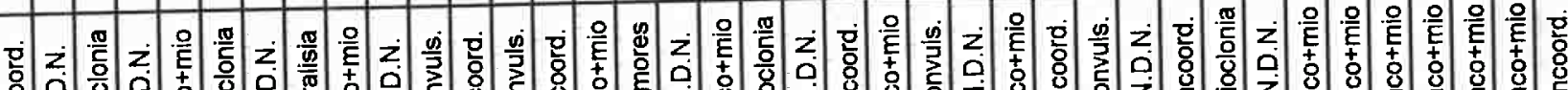

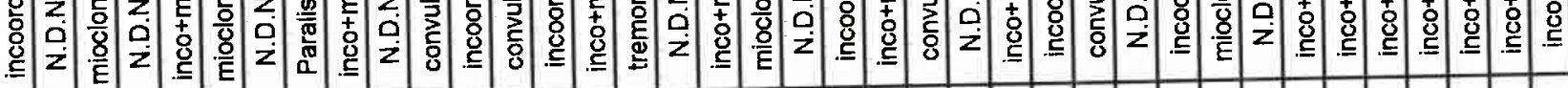

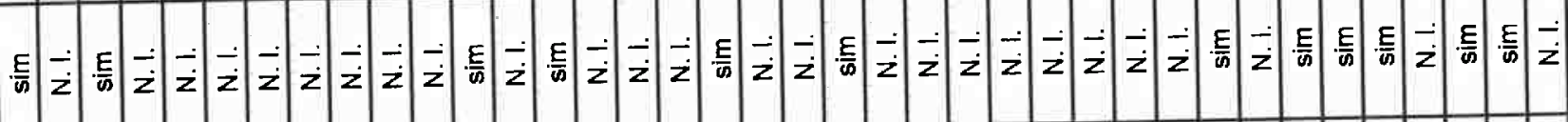

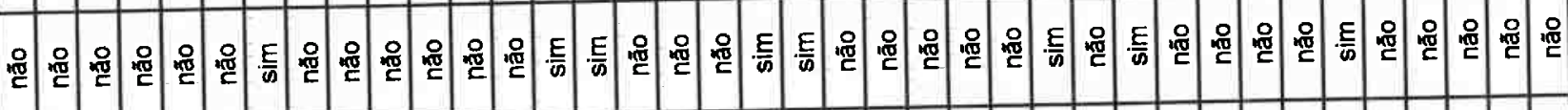

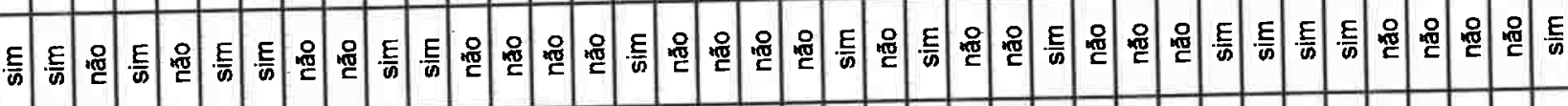

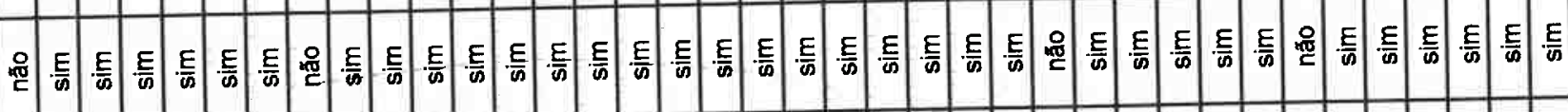

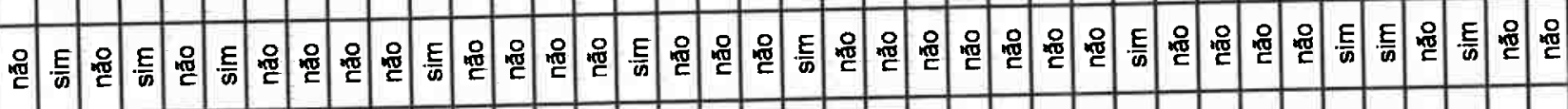

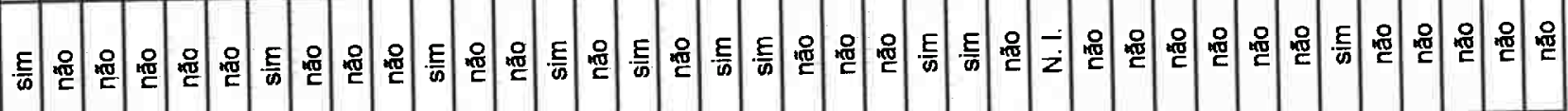

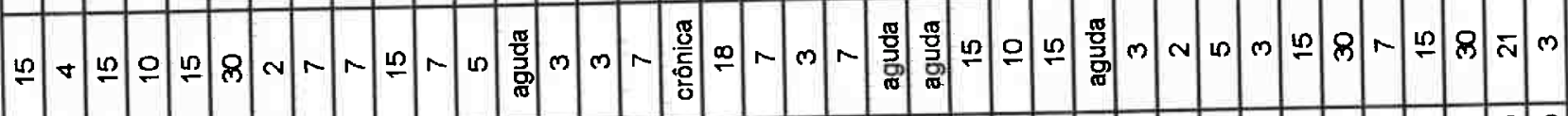

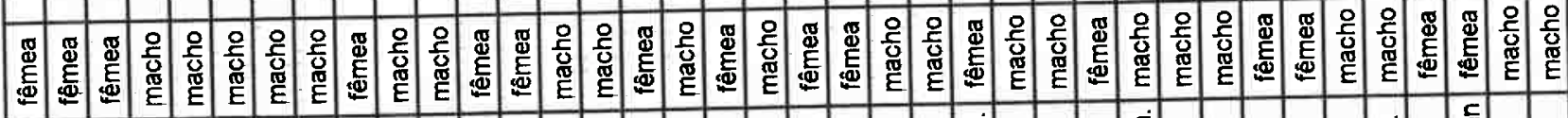

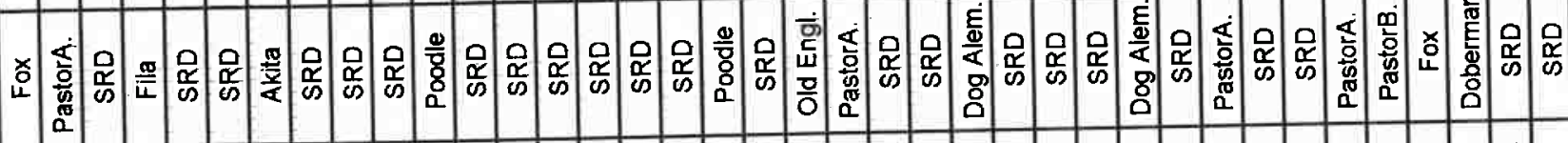

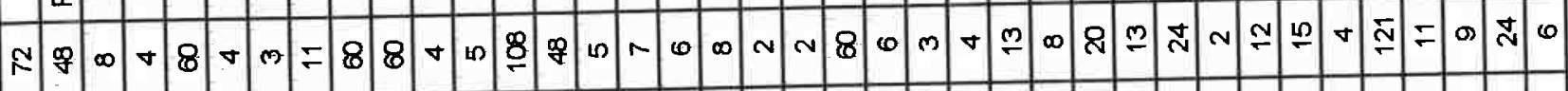

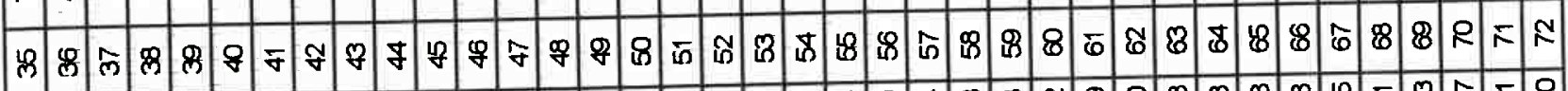

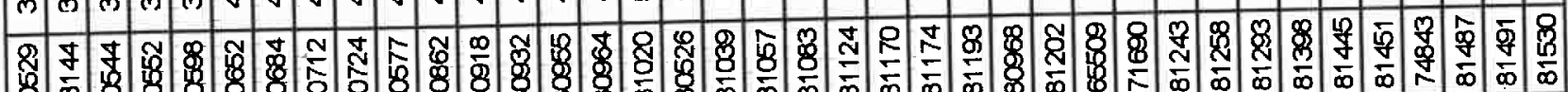

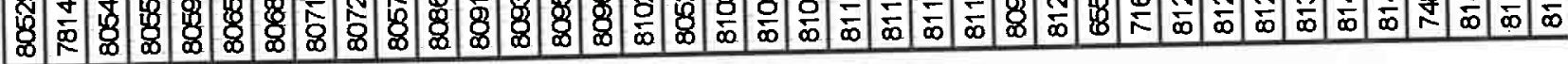




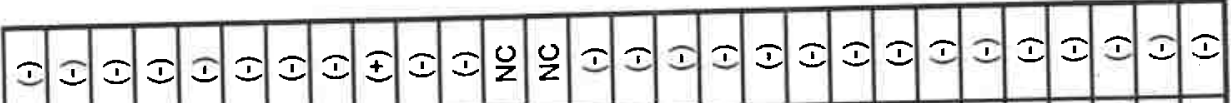

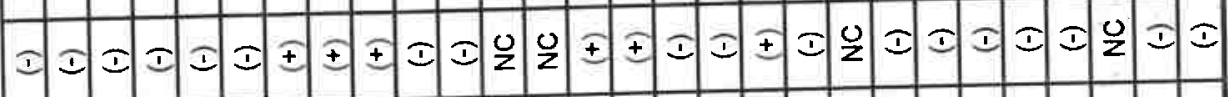

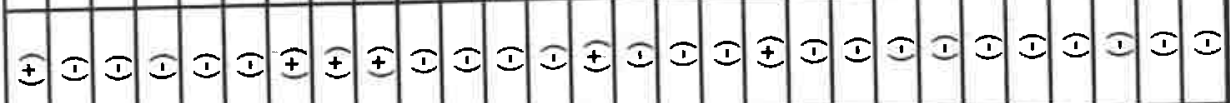

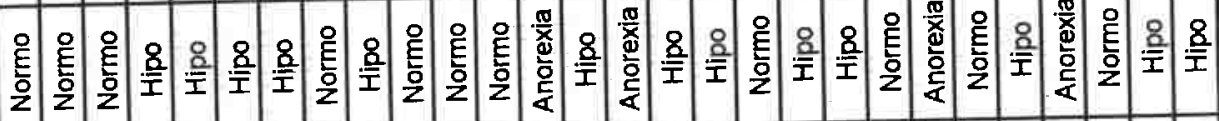

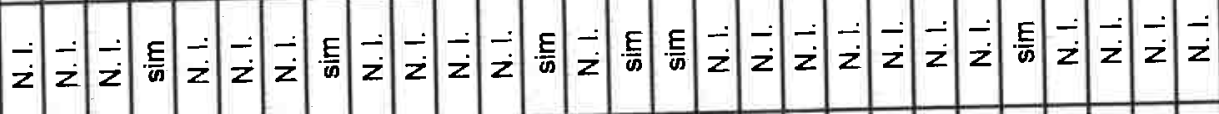

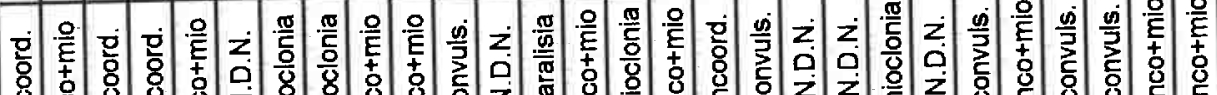

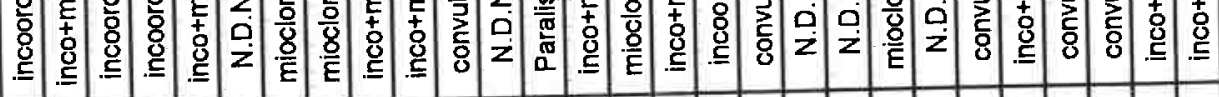

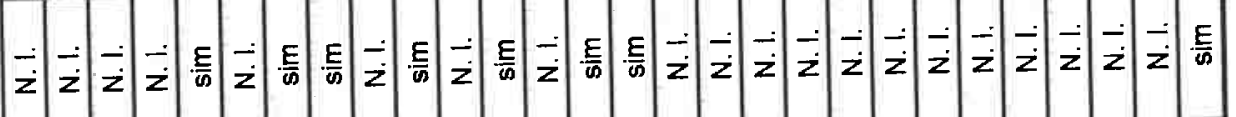

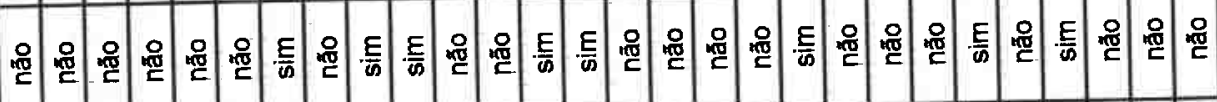
舟

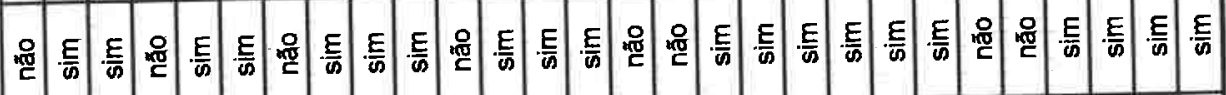

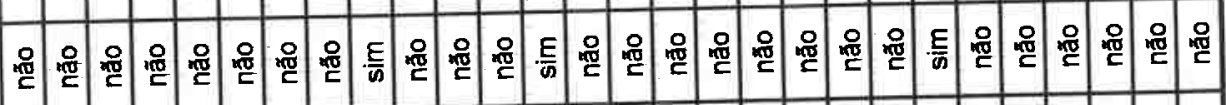

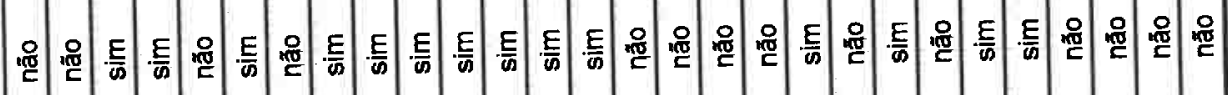

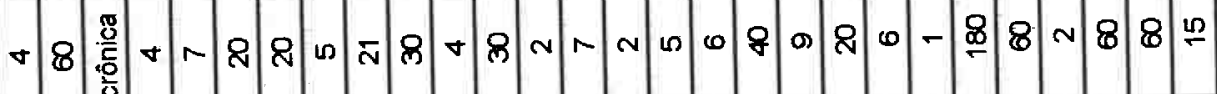

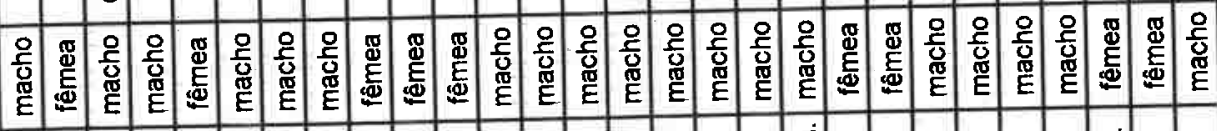

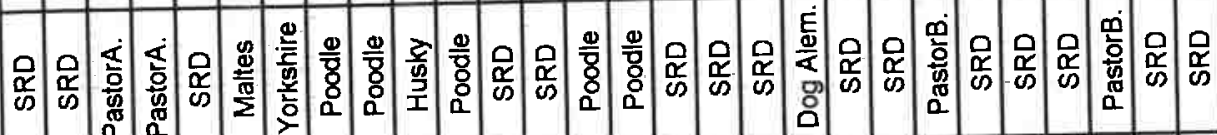

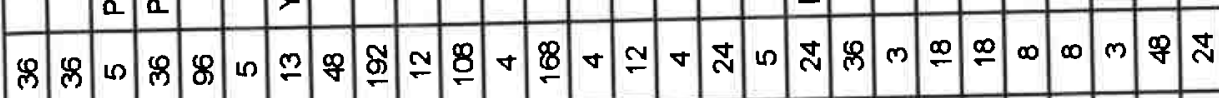
א.t.

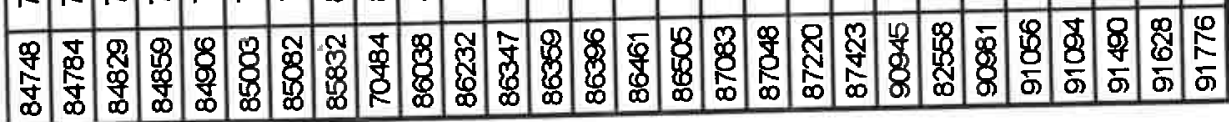

